\title{
PALEOBIOLOGY OF TITANOSAURS: REPRODUCTION, DEVELOPMENT, HISTOLOGY, PNEUMATICITY, LOCOMOTION AND NEUROANATOMY FROM THE SOUTH AMERICAN FOSSIL RECORD
}

\author{
RODOLFO A. GARCÍA ${ }^{1,8}$, LEONARDO SALGADO2,8, MARIELA S. FERNÁNDEZ ${ }^{3,8}$, IGNACIO A. CERDA ${ }^{1,8}$, ARIANA PAULINA CARABAJAL ${ }^{4,8}$, \\ ALEJANDRO OTERO ${ }^{5,8}$, RODOLFO A. CORIA ${ }^{6,8}$ AND LUCAS E. FIORELLI7,8
}

\begin{abstract}
1Instituto de Investigación en Paleobiología y Geología, Museo Provincial "Carlos Ameghino", Belgrano 1700, R8324CZH Cipolletti, Río Negro, Argentina. rodosnow@yahoo.com.ar;nachocerda6@yahoo.com.ar

Instituto de Investigación en Paleobiología y Geología, Isidro Lobo 516, R8332AKN General Roca, Río Negro, Argentina. salgadoleito@yahoo.com.ar 3Inibioma-Centro Regional Universitario Bariloche, Quintral 1250, R8400FRF Bariloche, Río Negro, Argentina.mariu_soledad_fernandez@hotmail.com 4Museo "Carmen Funes", Avenida Córdoba 55, Q8318EBA Plaza Huincul, Neuquén, Argentina. a.paulinacarabajal@conicet.gov.ar ${ }^{5}$ División Paleontología de Vertebrados, Museo de La Plata, Paseo del Bosque s/n, W1900FWA La Plata, Buenos Aires, Argentina.alexandros.otero@gmail.com ${ }^{6}$ Subsecretaría de Cultura, Provincia de Neuquén, Argentina - Instituto de Paleobiología y Geología, Universidad Nacional de Río Negro - Dinosaur Institute, Los Angeles County Natural History Museum - Museo "Carmen Funes", Avenida Córdoba 55, Q8318EBA Plaza Huincul, Neuquén, Argentina. coriarod@copelnet.com.ar ’Centro Regional de Investigaciones Científicas y Transferencia Tecnológica, Entre Ríos y Mendoza s/n, 5301 Anillaco, La Rioja, Argentina. Ifiorelli@crilar-conicet.com.ar ${ }^{8}$ Consejo Nacional de Investigaciones Científicas y Técnicas, Avenida Rivadavia 1917, C1033AAJ Ciudad Autónoma de Buenos Aires, Argentina.
\end{abstract}

\begin{abstract}
Much of the current paleobiological knowledge on titanosaur sauropods was attained in just the last fifteen years, in particular that related to reproductive and developmental biology. Recent years have also seen progress on other poorly explored topics, such as pneumaticity, muscle architecture and locomotion, and endocast reconstruction and associated structures. Some titanosaurs laid numerous, relatively small Megaloolithidae eggs (with diameters ranging from 12 to $14 \mathrm{~cm}$ ) in nests dug in the ground and, as known from the South American records, probably eggs of the multispherulitic morphotype. During ontogeny, certain titanosaurs displayed some variations in cranial morphology, some of them likely associated with the differing feeding habits between hatchlings and adults. The bone tissue of some adult titanosaurs was rapidly and cyclically deposited and shows a greater degree of remodeling than in other sauropods. Saltasaurines in particular show evidence of postcranial skeletal pneumaticity in both axial and appendicular skeleton, providing clues about soft tissue anatomy and the structure of the respiratory system. Titanosaurs, like all sauropods, were characterized by being fully quadrupedal, although some appendicular features and putative trackways indicate that their stance was not as columnar as in other sauropods. These anatomical peculiarities are significantly developed in saltasaurines, a derived group of titanosaurs. Compared with other sauropods, some titanosaurs seem to have had very poor olfaction but would have been capable of capturing sounds in a relatively wide range of high frequencies, although not to the extent of living birds.
\end{abstract}

Key words. Titanosaur. Reproduction. Embryos. Dentition. Histology. Pneumaticity. Locomotion. Neuroanatomy.

Resumen. PALEOBIOLOGÍA dE TITANOSAURIOS DE SUDAMÉRICA: REPRODUCCIÓN, DESARROLLO, HISTOLOGÍA, NEUMATICIDAD, LOCOMOCIÓN Y NEUROANATOMÍA. El conocimiento paleobiológico de los saurópodos titanosaurios, particularmente su reproducción y biología del desarrollo, fue alcanzado recién en los últimos quince años. En estos últimos años también se ha avanzado en temas poco explorados hasta el momento, como la neumatización, su arquitectura muscular y locomoción y la reconstrucción de partes blandas como el cerebro y estructuras asociadas. Algunos titanosaurios depositan sus numerosos y pequeños huevos megaloolitidos en nidos excavados sobre el suelo. Durante la ontogenia ciertos titanosaurios exponen algunas variaciones en su morfología craneana, algunas de estas probablemente asociadas con las diferentes maneras de alimentarse que tendrían los juveniles y los adultos. El tejido óseo de algunos titanosaurios adultos se habría depositado rápido y cíclicamente, exponiendo una mayor remodelación que en otros saurópodos. Los titanosaurios, particularmente los saltasaurinos, exponen una neumaticidad postcraneal en el esqueleto axial y apendicular, este carácter permite inferir la anatomía de sus tejidos blandos y de su sistema respiratorio. Los titanosaurios, como todos los saurópodos, estaban caracterizados por ser cuadrúpedos, aunque algunos caracteres apendiculares y las huellas indican que su postura no habría sido tan columnar como en otros saurópodos. Aquellas peculiaridades anatómicas están notoriamente desarrolladas en los saltasaurinos, un grupo de titanosaurios derivados. Comparado con otros saurópodos, algunos titanosaurios parecen haber tenido un pobre sentido del olfato, sin embargo estos habrían tenido la capacidad de captar sonidos de alta frecuencia en un rango relativamente amplio, aunque no tanto como las aves actuales.

Palabras clave. Titanosaurio. Neuroanatomía. Histología. Neumaticidad. Dentición. Reproducción. Embriones. Locomoción. 
TITANOSAURIA, defined by Wilson and Upchurch (2003) as the group formed by all descendants of the more recent common ancestor of Andesaurus Calvo and Bonaparte, 1991, and Saltasaurus Bonaparte and Powell, 1980, reached a nearly world-wide distribution by the Late Cretaceous (Salgado et al., 1997; Powell, 2003; Curry Rogers, 2005). This group is represented by more than 30 genera and is the geographically most widespread among sauropods. It inhabited all landmasses, i.e., current Asia (e.g., Nemegtosaurus Nowinski, 1971; Isisaurus colberti Jain and Bandyopadhyay, 1997), Africa (e.g., Rapetosaurus Curry Rogers and Forster, 2001), Europe (e.g., Lirainosaurus Sanz et al., 1999; Ampelosaurus Le Loeuff, 1995), North America (e.g., Alamosaurus Gilmore, 1922), Australia (e.g., Diamantinasaurus Hocknull et al., 2009) and Antarctica (Cerda et al., 2011). However, it is in South America where titanosaur remains are more common and most diverse. Anatomical and phylogenetic studies on this diverse group of sauropod dinosaurs embrace an extensive list of important contributions, which started in South America with Lydekker's pioneering work on Patagonian dinosaurs (Lydekker, 1893), followed by the classic von Huene monograph on Argentinean saurischians and ornithischians (Huene, 1929), and reaching the present day with the contributions of Powell (1986, 2003), Salgado et al. (1997) and García and Salgado (2013) in Argentina. The Brazilian titanosaurs have been well known since the late twentieth century (Powell, 1987a; Campos and Kellner, 1999; Kellner and Azevedo, 1999; Campos et al., 2005; Santucci and Bertini, 2006; Salgado and Carvalho, 2008, and Machado et al., 2013 among others), whereas the Chilean titanosaur record is scarce and only recently reported (Kellner et al., 2011).

Paleobiological studies on titanosaurs, although less numerous, experienced an important expansion over the last years (see Sander et al., 2008, 2010). Some lines of research, particularly those related to reproductive and developmental biology, were triggered by the discovery in 1997 of the fossil nesting-site known as Auca Mahuevo in Patagonia (Argentina) and the report of the first undisputable association of fossil eggs with titanosaur embryos (Chiappe et al., 1998, 2001; Salgado et al., 2005; García et al., 2010). Currently, a large number of articles and papers about the paleobiology of titanosaurs are available including aspects such as reproduction (e.g., Chiappe et al., 2004;
Simón, 2006; Salgado et al., 2009; Grellet-Tinner et al., 2012; Fernández et al., 2013), development (e.g., Chiappe et al., 2001; Salgado et al., 2005; García, 2007a; García et al., 2010), histology (e.g., Sander et al., 2006, 2011; Woodward and Leehman, 2009; Cerda and Powell, 2010; Cerda and Salgado, 2011; Company, 2011; Klein et al., 2012), pneumaticity (e.g., Wedel, 2007, 2009; Cerda et al., 2012), locomotion (e.g., Wilson and Carrano, 1999; Otero and Vizcaíno, 2008; Hohn, 2011; Otero, 2011) and neuroanatomy (e.g., Witmer et al., 2003, 2008; Paulina Carabajal, 2012). To a certain extent, some of the issues dealt with in those publications are complementary to each other, particularly osteohistology and developmental biology, because the bone-histology of a given organ usually reveals major aspects of its genesis, including information on the rate and timing of bone deposition (Sander, 2000).

Here we review and expand recent progress made by our research group on paleobiological aspects of titanosaurs, focussing on South American materials, and particularly on those coming from Patagonia. The goal of this work is to provide a synthesis and a critical appraisal of the current knowledge on titanosaur paleobiology obtained from South America and particularly from the Argentinean record over the last fifteen years, integrating as far as possible diverse aspects such as reproduction, development, osteohistology, pneumaticity, locomotion, and neurophysiology. For example, the eggs undoubtedly assignable to titanosaurs are restricted to some Late Cretaceous localities; paleohistological studies on titanosaur bones are few; the known and studied braincases are scarce and biomechanical analyses are only just beginning. Nevertheless, in spite of these limitations recent discoveries and studies on South American -and particularly Patagoniantitanosaurs provide some information that is relevant for understanding some paleobiological aspects of this clade.

Institutional abbreviations. CRILAR-Pv, Centro Regional de Investigaciones Científicas y Transferencia Tecnológica de La Rioja, Argentina, vertebrate paleontology collection; MACN-RN, Museo Argentino de Ciencias Naturales "Bernardino Rivadavia", Buenos Aires, Argentina, vertebrate paleontology collection; MAU-Pv, Museo "Argentino Urquiza", Rincón de los Sauces, Neuquén, Argentina, vertebrate paleontology collection; MCF-PVPH, Museo "Carmen Funes" de Plaza Huincul, Neuquén, Argentina, vertebrate paleonto- 
logy collection; MCS-Pv, Museo de Cinco Saltos, Río Negro, Argentina, vertebrate paleontology collection; MGPIFD-GR, Museo de Geología y Paleontología del Instituto de Formación Docente de General Roca, Río Negro, Argentina; MLPCS, Museo de La Plata, Cinco Saltos collection, La Plata, Argentina; MLP-Ly, Museo de La Plata, Lydekker's collection, La Plata, Argentina; MML-Pv, Museo Municipal de Lamarque, Río Negro, Argentina, vertebrate paleontology collection; MPCA-Pv, Museo Provincial "Carlos Ameghino", Río Negro, Argentina, vertebrate paleontology collection; MUCPh, Museo de Geología y Paleontología de la Universidad Nacional del Comahue, Neuquén, Argentina, paleohistology collection; PVL, Colección de Paleontología de Vertebrados de la Fundación-Instituto "Miguel Lillo", Tucumán, Argentina; UFRRJ, Universidade Federal Rural de Río de Janeiro, Seropédica, Brazil.

\section{TITANOSAUR REPRODUCTION Eggs and nests}

The amniote egg is one of the most significant novelties in the evolutionary history of vertebrates. The finding of whole eggs containing embryos is undoubtedly the only case that allows making a direct connection between the egg and its biological producer. However, this is rarely the case, and for this reason, different authors have developed a specific classification system for eggshell, using parataxonomy (Mikhailov, 1991; Mikhailov et al., 1996). This system allows comparisons of different types of eggshells without embryonic remains from all around the world (Fernández and Khosla, 2015).

The hypothesis that sauropods were oviparous was first confirmed by the discovery of hundreds of eggs containing embryos in Auca Mahuevo (Neuquén Province, Argentina) (Chiappe et al., 1998, 2005) and India (see Wilson et al., 2010). These discoveries allowed for the first time the linkage of a certain parafamily of fossil eggs -Megaloolithidae (Zhao, 1979) (Fig. 1)- to a specific clade of sauropods, i.e., Titanosauria (Chiappe et al., 2001, 2004; Wilson et al., 2010). Some authors claimed that megaloolithids were also laid by other types of dinosaurs (Kohring, 1989; Grigorescu, 2010) based upon rather disputable evidence, regarding which Grellet-Tinner et al. (2012) interpreted allochthony of those megaloolithid eggshell and hadrosaur remains found in Romania. Other types of fossil eggs were also assigned to titanosaurs in spite of the lack of associated embryos. Among these types are those recorded in Patagonia and Entre Ríos Province (Argentina), and Uruguay, with eggshells of the multispherulitic morphotype (Powell, 1992; Faccio, 1994). These are characterized by small spherulites that grow as long, mutually competing, narrow prisms, and adjacent prisms forming a network of irregular, crystaline walls that surround numerous large pore canals (Mones, 1980; Powell, 1985, 1987b, 1992; Mikhailov, 1991; Faccio, 1994; Manera de Bianco, 1996; Casadío et al., 2002; de Valais et al., 2003; Simón, 2006) (Fig. 1.7-8). In contrast, megaloolithid eggshells belong to the so-called tubospherulitic morphotype, with shell units sharply separate from each other throughout the eggshell thickness. These fanlike shell units can be traced up to the surface of the eggshell and the accretionary lines are semiconcentric (Mikhailov et al., 1996) (Fig. 1.3-6). Recent studies on similar eggs found in northwestern Argentina (La Rioja Province) (Tauber, 2007; Grellet-Tinner and Fiorelli, 2010) (Fig. 2.12 ) revealed that their eggshells display microscopic and ultrastructural characteristics somewhat resembling those of the megaloolithids found in Auca Mahuevo.

Megaloolithid eggs collected in Auca Mahuevo are spherical to subspherical, as are other megaloolithids found elsewhere, with diameters ranging from 12 to $14 \mathrm{~cm}$, and eggshell thicknesses varying between $1.00 \mathrm{~mm}$ and 1.78 $\mathrm{mm}$, with an average thickness of $1.4 \mathrm{~mm}$ (Chiappe et al., 1998) (Fig. 3.1-3). The smallest megaloolithid recorded up to date in Patagonia comes from the Salitral de Santa Rosa area (Río Negro Province), with a diameter of $9.42 \mathrm{~cm}$ (Salgado et al., 2009) (Fig. 1.1). However, eggs of this type collected from other continents are normally larger (consider, for instance, the megaloolithids of "titanosaurid-type III" from India, and Megaloolithus siruguei Vianey-Liaud et al., 1994 from France, with diameters of up to $20 \mathrm{~cm}$ ) (Vilá et al., 2006; Sander et al., 2008). As noted above, Argentinean and Uruguayan eggs of the multispherulitic morphotype are invariably larger than the Argentinean megaloolithids, reaching diameters of $18-21 \mathrm{~cm}$ in Salitral de Santa RosaSalitral Ojo de Agua (Río Negro Province) (Powell, 1992; Salgado et al., 2007), and have invariably much thicker eggshells, exceeding $6 \mathrm{~mm}$ in thickness at these localities (Salgado et al., 2007), and reaching a maximum thickness of $7.94 \mathrm{~mm}$ in Sanagasta (Grellet-Tinner and Fiorelli, 2010) 

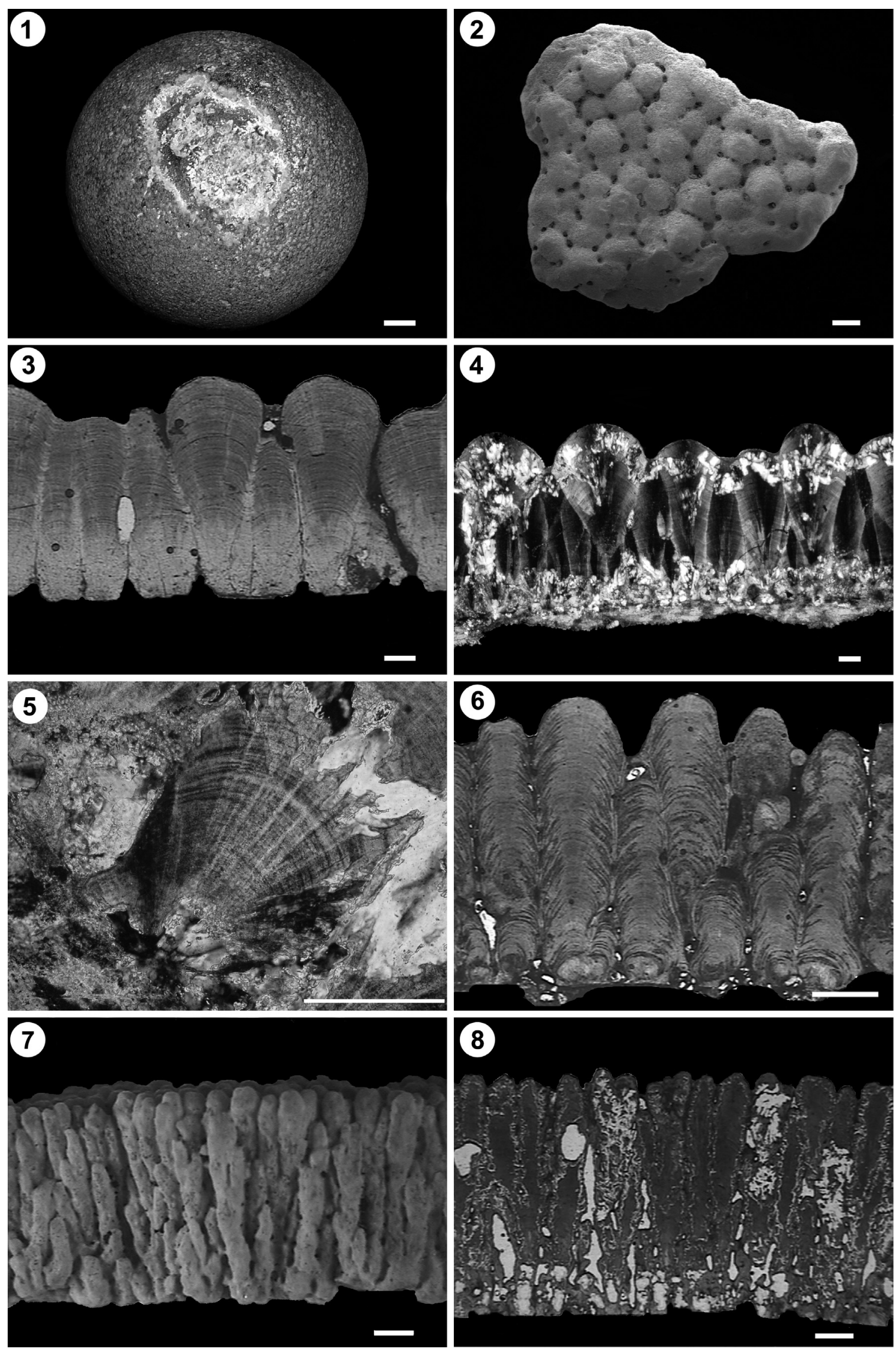
(Fig. 2.3-5). The Sanagasta nesting site shed insights on the reproductive behavior of a group of titanosaurs, suggesting colonial behavior and site fidelity with possible phylopatry (Grellet-Tinner and Fiorelli, 2010). Geological, paleontological and taphonomic evidence (Fiorelli et al., 2012, 2013) suggests that the Sanagasta titanosaurs chose a hydrothermal area as nesting-ground, an opportunistic environment-dependent reproduction relationship with a geothermally active paleoenvironment, and an examination of the biological adaptation of the egg is warranted in this context (Grellet-Tinner et al., 2012). These authors hypothesized the outer eggshell surfaces of the eggs in the hydrothermal substrate display thick eggshells which were thinned by dissolution and acidification, a process that had a great effect on the physiology, development and therefore on the progressive incubation of the embryos. The presence of extremely thick eggshells in eggs laid in geothermal environments represents a natural reproductive adaptation to resist chemical dissolution in this extreme environment by buffering external acidic hydrothermal fluids (Grellet-Tinner et al., 2012).

In Salitral de Santa Rosa and Salitral Ojo de Agua, as well as in Sanagasta, thin (megaloolithids) and thick-shelled eggs (those of the multispherulitic morphotype) are found in the same levels and paleoenvironments (Salgado et al., 2007). However, in these sites there is no evidence of hydrothermal structures, although more research is needed on this subject. At most, the hypothesis proposed for explaining the thick eggshell of the eggs from Sanagasta does not represent a generalized case and could not be valid for the thickshelled eggs from Patagonia. Although it is also true that reliably unknown environmental factors nesting sites in Patagonia are unknown.

The occurrence of external nodes in the megaloolithid eggshell (Fig. 1.2) and in eggshells of the multispherulitic morphotype from Patagonia, Entre Ríos, La Rioja and Uruguay (Fig. 2.3), provide some clues to the reproductive behavior of titanosaurs. Some authors suggest that most non-avian dinosaurs buried their eggs completely, or that their eggs were eventually covered with vegetal matter, in view of their high shell porosity (Seymour, 1979; Sabath, 1991; Grigorescu et al., 1994; Deeming, 2002, 2006). In the case of the megaloolithid-laying titanosaurs, however, this is not obvious. Although the conductance of their eggs is in general higher than that of bird eggs (almost all birds do not bury their eggs), it is much lower than that of other dinosaurs except Megaloolithus patagonicus Calvo et al., 1997 (Grellet-Tinner et al., 2012) and perhaps in Megaloolithus siruguei. In agreement with their relatively low conductance, lithological and paleoichnological data suggest that the megaloolithid eggs from Auca Mahuevo would have been hardly buried (Jackson et al., 2008; Sander et al., 2008; Vilá et al., 2010b). This view contrasts with the opinion of Chiappe et al. (2004) and Grellet-Tinner et al. (2006, 2012) who claim to have found vegetal matter inside the nests (see Sander et al., 2008 for a different interpretation). In this regard, there is an obvious incompatibility between the idea that the superficial nodes of the megaloolithids were an adaptation for avoiding obliteration of the pore openings and the hypothesis that these eggs were not buried. It must be noted that both morphological and microstructural characteristic of the eggshell from Auca Mahuevo are identical, and the numerous embryonic remains suggest that these specimens were laid by the same titanosaur species (Chiappe et al., 1998; García et al., 2010).

Interpretations regarding nest construction and incubation strategy employed by titanosaurs have noted that these reptiles probably burried their eggs in organic matter

Figure 1. Titanosaur eggs and eggshells from Salitral de Santa Rosa (Río Negro, Argentina). 1, Megaloolithid egg 434/P/96 (provisional catalogue number of the Museo Regional de Valcheta, Río Negro, Argentina); 2, SEM photograph of an megaloolithid eggshell surface (MML-Pv 30), showing the external nodes and pores; 3, radial section of a megaloolithid eggshell (MML-Pv 21), under transmitted light, showing the fanshaped eggshell units and the arched accretionary lines; 4, radial section of a megaloolithid eggshell (UFRRJ-1), under polarized light, showing the fan-shaped eggshell units; 5 , detail of the mammilary structure of a megaloolithid eggshell (UFRRJ-1), showing the arched accretionary lines crossed by radial wedge lines; 6 , radial section of a relatively thick megaloolithid eggshell (MML-Pv 22) showing the fan-shaped eggshell units and the arched accretionary lines; 7, radial section of an eggshell of multispherulitic morphotype (MML-Pv 38) under lupe, showing the irregular network of narrow eggshell units that surround numerous large pore canals; 8 , radial section of an eggshell of multispherulitic morphotype (MML-Pv 23), under transmitted light. Scale bars $1=1 \mathrm{~cm} ; 2-4,6-8=1 \mathrm{~mm} ; 5=2 \mathrm{~mm}$. 


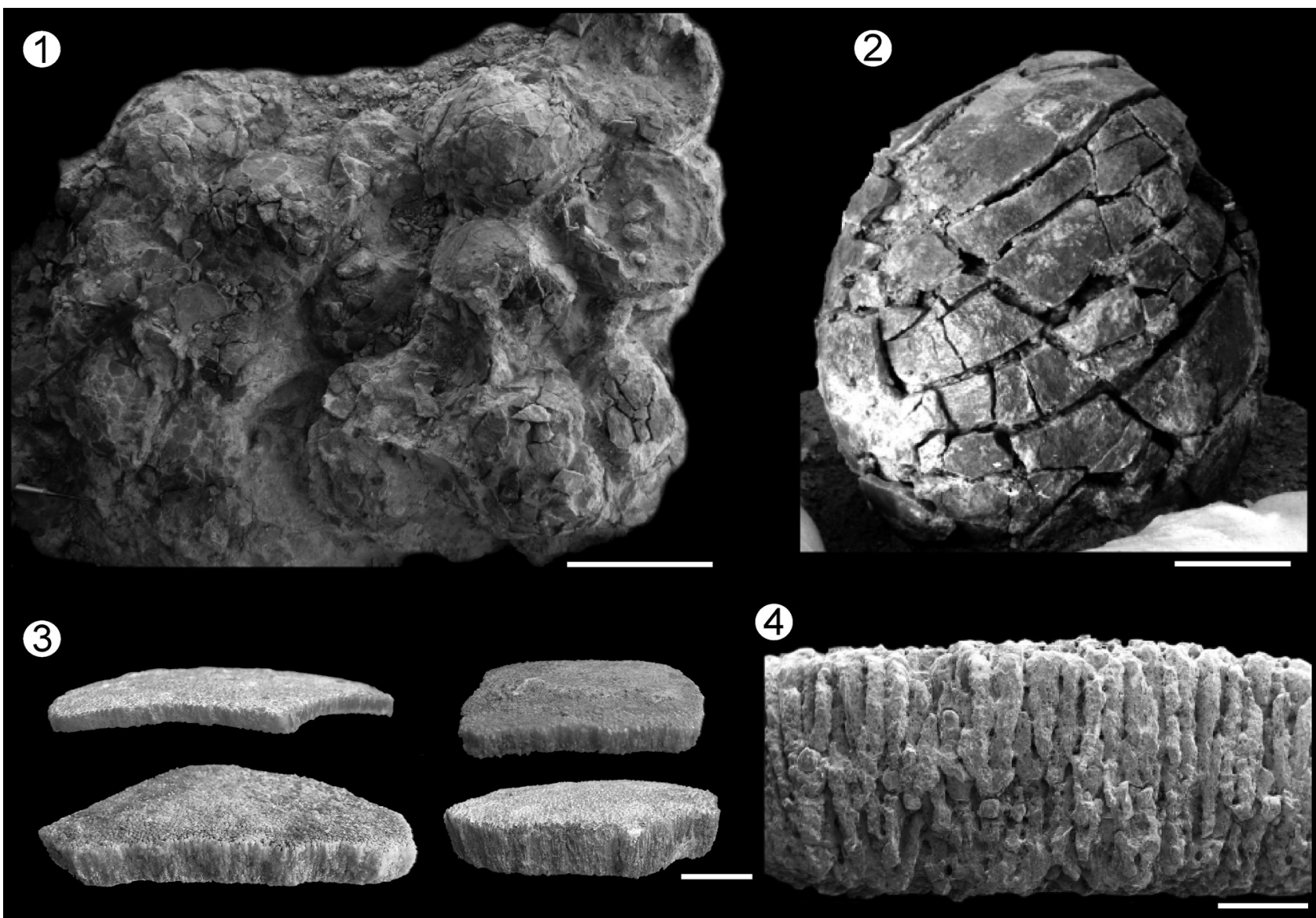

5

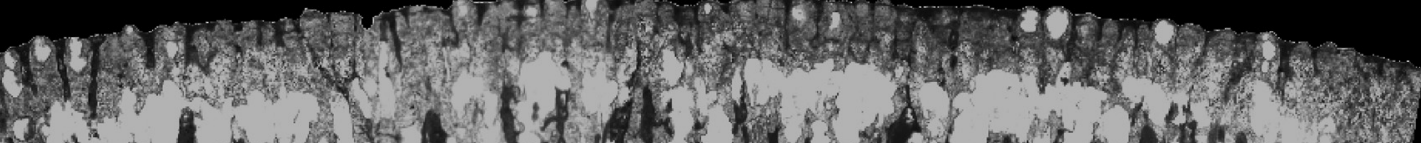

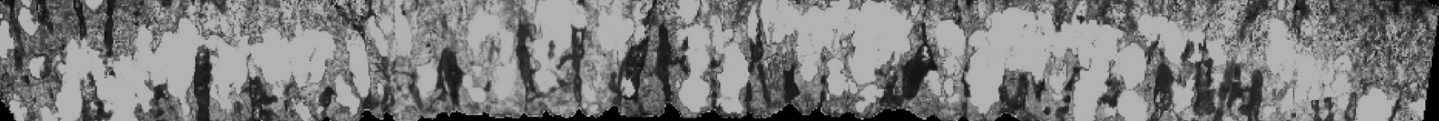

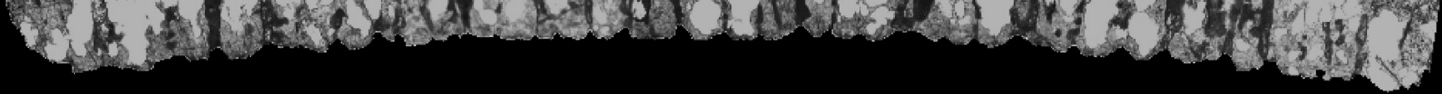
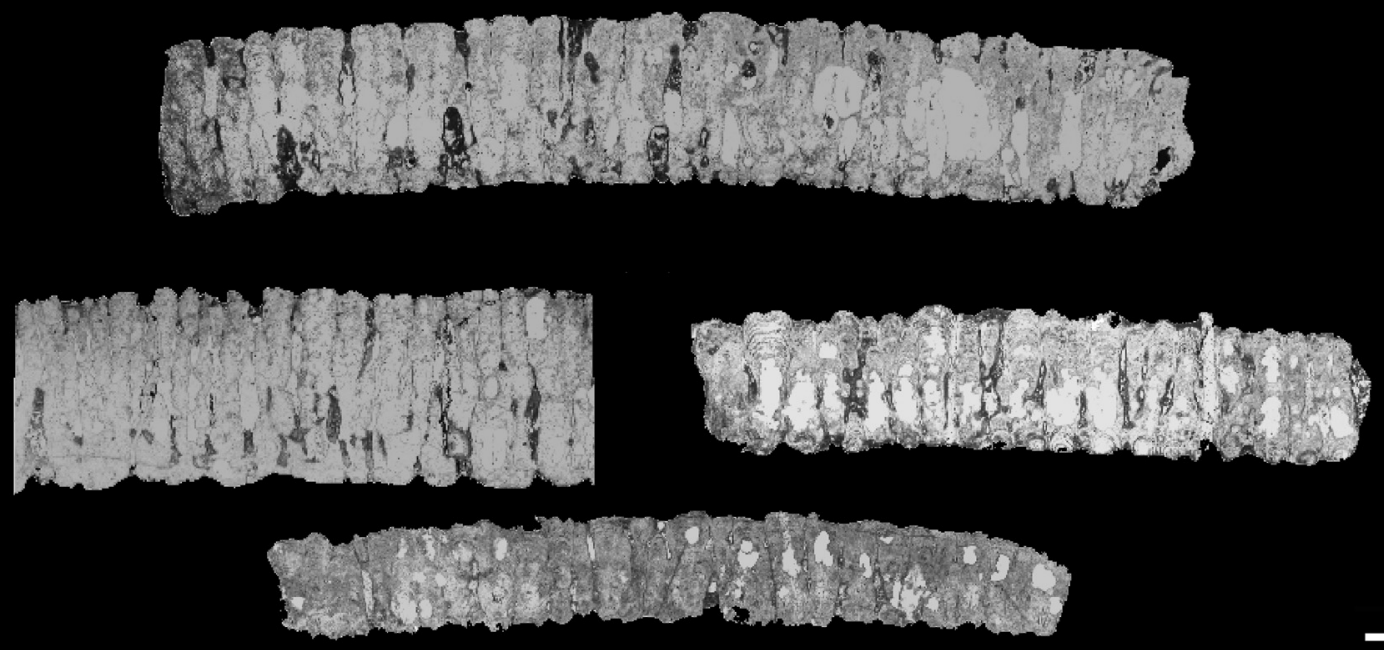
as crocodiles do (Grellet-Tinner et al., 2006). It has been inferred that these animals built their nest with organic matter, laying a large number of eggs with a conspicuous external ornamentation (Fernández et al., 2013; Simoncini et al., 2014). Given that it is well known that crocodile eggshells experience changes during incubation (Ferguson, 1985; Simoncini et al., 2014), the low water-vapor conductance value of Auca Mahuevo eggs should be carefully considered. If the analyzed eggshell samples have been taken from an egg that stopped its development during its first days of incubation, we will probably obtain lower values than if the samples were taken from an egg that stopped its development at the final stage of incubation. Future studies should resolve the variability in vapor conductance values to assess the impact of the different stages of incubation. Auca Mahuevo provides a unique opportunity to conduct this type of study. Here we endorse a burial-strategy incubation based on the interpretation made by Grellet-Tinner et al. (2006).

The conductance index of the Argentinean eggs of the multispherulitic morphotype is higher than that of the Argentinean megaloolithids. In fact, Salgado (2000) calculated 1428.33 as the $\mathrm{G}_{\mathrm{H} 2 \mathrm{O}}$ value for an eggshell of this morphotype from Salitral Ojo de Agua (Río Negro Province). Thus, it is probable that these clutches had also been covered by sediment and/or vegetal matter.

Dinosaur nests attributed to titanosaurs from different continents (Lapparent, 1958; Kerourio, 1981; Mohabey, 1984) share characteristics that indicate similar strategies for different taxa, which in turn allow inferring a common nesting strategy for this clade. Titanosaur nests consist of shallow depressions, which were excavated in the ground and rimmed by sediment removed from the excavation (Vilá et al., 2010b). In Auca Mahuevo, this structure could be documented only in those few cases in which the nests were dug in sandy fluvial channels and later covered by mud (Chiappe et al., 2004). Most of the nest structures were apparently excavated in mud and covered by the same kind of sediment, which makes virtually impossible their visualization. In Salitral Ojo de Agua and Salitral de Santa Rosa, eggs of the multispherulitic morphotype also seem to have been laid in shallow (probably excavated) depressions (Salgado et al., 2007: fig. 5A). This kind of nest structure has not been recorded yet anywhere else.

The clutches from Auca Mahuevo contain between 15 and 34 megaloolithid eggs (Chiappe et al., 1998, 2004) (Fig. 3.1-2). In Salitral de Santa Rosa (Río Negro Province), a clutch of 14 megaloolithid eggs was collected (Fig. 3.6), which is consitent with those from Auca Mahuevo (Salgado et al., 2007). In Catalonia, megaloolithid clutches seem to have fewer number of eggs (a maximum of 6-7, according to Sander et al., 2008). In this regard, European and Patagonian titanosaurs were supposed to have developed quite different reproductive strategies (Sander et al., 2008). However, Vilá et al. (2010b) recently reported clutches of up to 28 megaloolithid eggs at the Pynes locality (southern Pyrenees), which is much closer to the maximum number reported in Auca Mahuevo. Furthermore, they interpret that the lower number of megaloolithids per clutch reported in many European and Asian sites is due to erosion (or predation; see Wilson et al., 2010) and that all megaloolithid laying titanosaurs had the same reproductive behavior (Vilá et al., 2010b).

With respect to the basic titanosaur clutch morphology, Moratalla and Powell (1994) documented two different styles of oviposition: eggs in clutches/nests (like those recorded in Auca Mahuevo), and eggs in lined-up series. In Auca Mahuevo, most egg clutches are in sub-circular to sub-elliptical depressions, which vary in size from aproximately 100 to $140 \mathrm{~cm}$ across their maximum planview axes

Figure 2. Clutch, egg and eggshells of multispherulitic morphotype from Sanagasta, La Rioja Province, Argentina, attributed to neosauropods, probably titanosaur. 1, clutch containing over twenty eggs from the main Sanagasta nesting site; 2, complete egg from the clutch \#6, Sanagasta, sub-site A (CRILAR-Pv 400); 3, eggshells of multispherulitic morphotype of different thicknesses; 4, SEM photograph of an eggshell fragment from the sub-site $G$ (see Fiorelli et al., 2012); 5, radial sections of eggshells of multispherulitic morphotype from the clutch \#10, subsite $\mathrm{E}$, under transmitted light. For more information on the geology, paleontology and paleobiology of the Sanagasta nesting site see GrelletTinner and Fiorelli (2010); Fiorelli et al. $(2012,2013)$ and Grellet-Tinner et al. (2012). Scale bars $1=20 \mathrm{~cm} ; 2=5 \mathrm{~cm} ; 3=1 \mathrm{~cm} ; 4-5=2 \mathrm{~mm}$. 
(Chiappe et al., 2004). In Lérida (Spain), a nest with 6 to 8 eggs arranged circularly is conical in radial view (Lapparent, 1958; Kerourio, 1981).

The linear style of oviposition has been observed in many localities of Europe, such as in Rennes-Le-Château, France (Coombs, 1989). At this place, the eggs are sequenced in arches (each one with between 15 and 22 eggs) whose radii vary between 1.3 and 1.7 m (Coombs, 1989). The eggs in arches were thought to have been laid by a rotating single female, pivoting on its forelimbs (Moratalla and Powell, 1994). This particular clutch morphology was not recorded among Patagonian megaloolithids, but in Salitral Ojo de Agua some clutches of the multispherulitic morphotype seem to be in straight rows (Moratalla and Powell, 1994).

At Auca Mahuevo, the few undisputable nests are elongate and kidney-shaped, with diameters ranging from 1 to $1.4 \mathrm{~m}$ and depths varying from 10 to $18 \mathrm{~cm}$. The same contour can be seen in the clutch from Santa Rosa. The eggs from Santa Rosa and Auca Mahuevo are staked at different levels, as recorded in many cases in the Pyrenee Mountains (Sander et al., 2008; Vilá et al., 2010b). This strongly supports the same mode of nest excavation, dug up -according to these authors- by one of their pes. This mode of excavation differs from that proposed by Apesteguía (2004a), who based on certain anatomical features of the axial and appendicular skeleton claimed that titanosaurs would have excavated their nests using their forelimbs (see Fowler and Hall, 2011).

In Sanagasta, the clutches with more than 25 eggs consist of two superposed rows wherein the greater amount of eggs is in the upper row (Grellet-Tinner and Fiorelli, 2010). However, most of the Sanagasta clutches with less than 15 eggs display varied arrangements. The clutches at Sanagasta display abiogenic accumulation patterns, some in disorganized clusters or in associated mass accumulations but in most cases showing several arrangements such as linear organization or a typical Faveoloolithidae pattern (Fig. 2.1) (Fiorelli et al., 2013). The egg-clutches are always associated to paleohydrothermal structures, fabrics, and facies. Their distribution is directly related to the paleorelief, and their precise location is closely constrained by thermal paleotemperatures (30 to $40^{\circ} \mathrm{C}$ ) for optimal incubation (Fiorelli et al., 2012, 2013).

It is important to note that we have not considered whether all the eggs of a single nest/clutch were laid by a single female, as well as whether a single female laid more than one clutch per season. In this regard, Sander et al. (2010) proposed that the small clutch size and the size of the eggs suggest that several clutches were produced by a titanosaurid female per season. This point is crucial if we aim at understanding the reproductive behavior of titanosaurs. In this regard, it is important not to dissociate the paleoenvironment of the nesting site based on appraisals of their reproductive behavior. Reproduction in oviparous vertebrates is usually more constrained by environmental forces than in viviparous amniotes and careful nesting-site selection becomes a critical factor (Shine and Harlow, 1996; Kolbe and Janzen, 2002; Grellet-Tinner and Fiorelli, 2010).

\section{Paleoenvironment}

Virtually all sites with megaloolithid eggs reflect distal alluvial or coastal plains (possibly even tidal plains) (Sander et al., 2008), which differ from the other environment presumably preferred by most titanosaurs: according to Calvo et al. (1997), Salgado et al. (2009), Garrido (2010), and Fiorelli et al. (2012) there is a range of specific paleoenvironmental conditions among the different titanosaur nesting sites discovered to date, giving an idea of the versatility of these dinosaurs in this respect.

At Auca Mahuevo, the paleoenvironment of the Anacleto Formation (early Campanian) varies between the lower and

Figure 3. 1, Field work at Auca Mahuevo (Neuquén Province, Argentina); workers excavating some titanosaurian clutches; 2, titanosaurian clutch, with 30-32 megaloolithid eggs, from Auca Mahuevo; 3, view of egg-bearing level of the Anacleto Formation at Auca Mahuevo, which consists mostly of siltstones deposited in floodplains (the marks point out the exact location of the clutch); 4, overview of the Allen Formation at Bajo de Santa Rosa (Río Negro Province, Argentina). The egg levels are mostly pelites and sandstones, which correspond to brackish lagoons in a supratidal environment, associated with aeolian sands (dunes) and deposits of ephemeral rivers; 5 , an isolated egg of multispherulitic morphotype from Bajo de Santa Rosa; 6, a clutch of 15 megaloolithids from the same locality. 

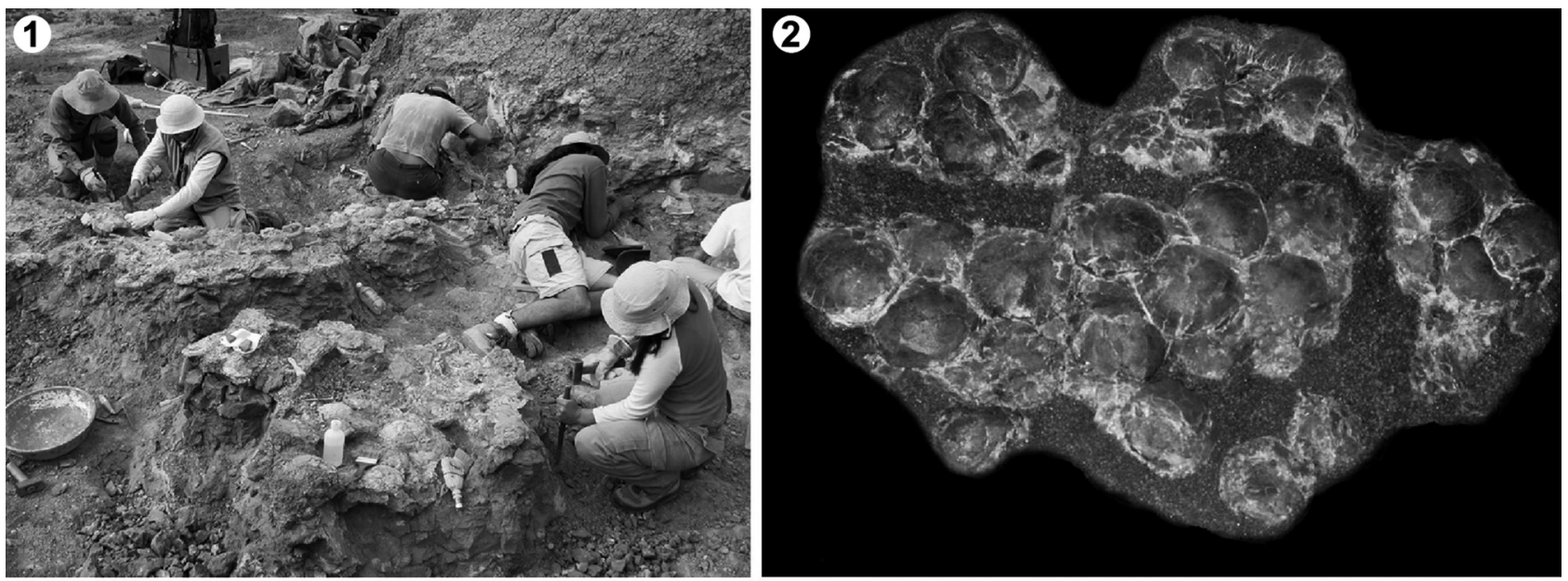

\section{3}

4
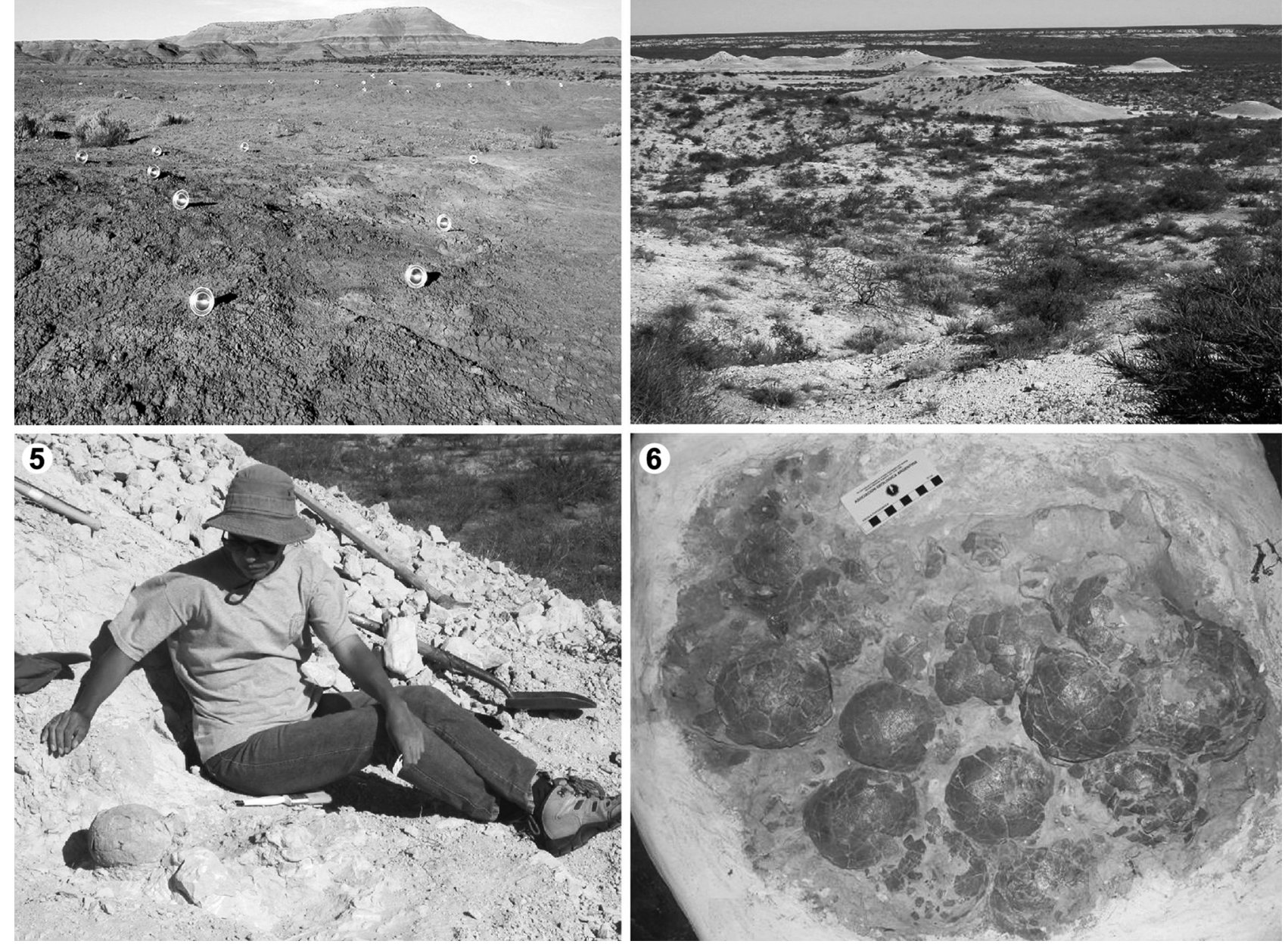
the upper sections of the outcrops (Garrido, 2010). The lower section (which contains the four egg-bearing horizons), consists of meandering fluvial deposits progressing to distal floodplains at the locality Los Barreales $(15 \mathrm{~km}$ north Auca Mahuevo) (Fig. 3.3). In this section, the largest concentrations of eggs are in areas close to the rivers (Garrido, 2010). In Neuquén city, the eggs of Megaloolithus patagonicus lie in fluvial sandstones deposited in braidplains, with presence of paleosoils (Calvo et al., 1997). In Salitral de Santa Rosa, the paleoenvironment in which the Allen Formation (bearing both megaloolithids and eggs of the multispherulitic morphotype) was deposited includes brackish lagoons in a supratidal environment, associated with aeolian sands (dunes) and deposits of ephemeral rivers (Fig. 3.4). In Sanagasta (La Rioja Province, Argentina), the paleoenviroment of Los Llanos Formation is characterized by an epithermal setting, with hot-spring structures such as alkaline fountain geysers, domal mounds, stratified terraces of calcite, ponds, and travertine dam and minidam-like structures; also common are acidic structures, facies and minerals such as siliceous geodes, opalized sediments, botryoidal facies, and other associated hotstream deposits (Fiorelli et al., 2012). Associated with the clutches and regularly distributed in the site, there are microstromatolith, microbialites (biosilicifications) and fossil cyanobacteria and 'pinnate' diatoms, which are symptomatic of an extreme hydrothermal paleoenvironment (GrelletTinner and Fiorelli, 2010; Fiorelli et al., 2012).

\section{Colonial nesting behavior}

Megaloolithid nests and clutches, as well as clutches of multispherulitic eggs found in Argentina and Uruguay, are rarely isolated. On the contrary, it is usual to find large concentrations of eggs, clutches or nests in the same areas and stratigraphic levels (Carpenter, 1999; Salgado et al., 2007, 2009; Vilá et al., 2010a, 2010b; Fernández, 2013). Clutches in the same horizon are usually assumed to be synchronous, although the precise synchronicity is difficult to test in some deposits (e.g., in Santa Rosa and India), which would be fundamental to infer colonial nesting behavior. In other cases (Auca Mahuevo), the synchronicity is much more evident. Synchronicity and regular distribution of the clutches in Auca Mahuevo strongly suggest that these dinosaurs (at least the females) would have aggregated during the ovopositional season (Chiappe et al., 2005). The Auca Mahuevo site is a large outcrop that yielded clutches in four distinct horizons, so the distribution pattern of nests in this area resembles those of nesting colonies of living birds. For example, marine birds commonly return every year to the same area for nidification. If such an area gets repeatedly buried preserving the nests in the fossil record, it would produce a distribution pattern similar to that of the nests at Auca Mahuevo.

All megaloolithids recorded at Auca Mahuevo are nearly identical in shape, microstructure and embryonic content, which is assumed here to indicate the existence of a single titanosaur species (as also inferred by Chiappe et al., 2005). Up to now, only one parataxon of multispherulitic morphotype was reported in Sanagasta; there, Grellet-Tinner and Fiorelli (2010) interpreted repetitive oviposition of a single group of neosauropods with colonial behavior and site fidelity. In contrast, at Salitral de Santa Rosa megaloolithids vary importantly in eggshell thickness and microstructure (Salgado et al., 2009) (Fig. 1.3-6). This, coupled with the fact that at such locality megaloolithid clutches are nearly contiguous with eggs or clutches of multispherulitic morphotype, suggests more than one titanosaur species in the area (Salgado et al., 2007). Nevertheless, as noted above, we cannot claim that these clutches were laid at the same time.

Many authors (Moratalla and Powell, 1994; GrelletTinner et al., 2006) have hypothesized that titanosaurs were precocial, as are living crocodiles. This is inferred in part because of the absence of neonate and adult remains in the neighborhood of the clutches attributed to these dinosaurs (in Auca Mahuevo and in other localities). Additionally, the short distance between clutches would have prevented the permanent presence of adult individuals in the nest surroundings (Chiappe et al., 2005).

García (2008) recently presented evidence supporting the opposite view that titanosaurs -at least those from Auca Mahuevo- were altricial. Assuming that titanosaurs followed a sequence of ontogenetic stages similar to modern birds, and taking into account the stages established by Hamburger and Hamilton (1951), the embryos from Auca Mahuevo would lie in stages 36-37, within the 42 prenatal stages (usually cited as $\mathrm{HH}$-stages) established for birds (see also Starck, 1993). Thus, the degree of development of the Patagonian embryos is similar to that recorded in al- 
tricial birds at the same stage, which suggests that titanosaurs followed a similar reproductive strategy. Finally, the embryos from Auca Mahuevo present an 'egg-tooth'like structure. This structure is more frequent in altricial than in precocial birds, although it is present in many crocodiles and snakes (García, 2007a, 2008, see below).

Titanosaurs would have reproduced periodically. At Auca Mahuevo there are four egg-bearing horizons. Two of these can be splitted into two sublevels apparently corresponding to two consecutive egg-laying events. Thus, evidence from Auca Mahuevo suggests at least six (not necessarily consecutive) seasons of colonial aggregation for these titanosaur populations (Chiappe et al., 2005).

\section{TITANOSAUR DEVELOPMENT}

\section{Embryological osteology}

The titanosaur embryos discovered at Auca Mahuevo are represented exclusively by cranial material. The skulls are proportionally large and short (34.5-39 mm long, and 24-24.5 mm high), with a circular orbit that comprises approximately one third of the total skull length (Chiappe et al., 2001; Salgado et al., 2005; García et al., 2010) (Fig. 4.1).

In lateral view, the antorbital fenestra of the embryonic skull is placed rostrally to the orbit and dorso-posteriorly to the small subcircular preantorbital fenestra (García, 2007b) (Fig. 4.1). The rostral tip of the premaxillae has a bony protuberance, which has been interpreted as analogous to the 'egg-tooth' of many living reptiles and birds (García, 2007a) (Fig. 4.1-4). According to this interpretation, the limbs of the titanosaur embryos, at least in this species, would have played only a complementary role in hatching (MuellerTöwe et al., 2002) and not an exclusive one as claimed by Carpenter (1999).

\section{Ontogenetic variation}

Assuming that the cranial morphology of the adult titanosaurs from Auca Mahuevo was overall similar -in terms of their basic structural plan- to that in other titanosaurs such as Nemegtosaurus (Nowinski, 1971; Wilson, 2005b) and Tapuiasaurus Zaher et al., 2011, it is evident that the Patagonian dinosaurs experienced a deep ontogenetic modification in this part of the skeleton (Fig. 5) (García, 2008). Although there are some differences between the titanosaur skulls mentioned above, they share a basic structural plan that is remarkably different from that of the Auca Mahuevo embryos. Some of these differences would imply ontogenetic changes supposed to be paleobiologically significant, as discussed below.

Relative lengthening of the snout (and correlated changes). The rostral portion of the embryonic skull (as seen in MCF-PVPH 272, MCF-PVPH 263) (measured from the distal end of the premaxilla up to the orbital border of the lacrimal) never surpasses $50 \%$ of the total skull length. On the other hand, adult sauropods have a relatively elongated skull, where the antorbital region varies between $56 \%$ and $68 \%$ of the total skull length (e.g., Shunosaurus lii Dong et al., 1983 [Zheng, 1996; Chatterjee and Zheng, 2002], Camarasaurus lentus Marsh, 1889 [Madsen et al., 1995], Diplodocus longus Marsh, 1878 [Hatcher, 1901; Berman and McIntosh, 1978], Brachiosaurus brancai Janensch, 1914 [Janensch, 1935-36], Nemegtosaurus mongoliensis Nowinski, 1971 [Wilson, 2005b], Rapetosaurus krausei Curry Rogers and Forster, 2004, and Tapuiasaurus macedoi Zaher et al., 2011). The ontogenetic elongation of the snout of the Auca Mahuevo titanosaur involves mainly the premaxillae and maxillae, with a notable expansion of their nasal processes and caudal portions, respectively (Fig. 5; see also García, 2008). A similar morphological change in ontogenetic trajectory is observed in the snout of the basal sauropodomorphs Massospondylus Owen, 1854 (Attridge et al., 1985; Reisz et al., 2005, 2010), and Mussaurus Bonaparte and Vince, 1979 (Pol and Powell, 2007).

Morphological changes in the premaxilla. In dorsal view, the angle determined by the interpremaxillary and the premaxillo-maxillary sutures (the last measured by Upchurch [1999] as the segment linking the rostral end of the suture and the caudal margin of the subnarial foramen), differs among the different sauropods (in Rapetosaurus and in the neuquenian embryos, because of the absence of subnarial foramen, that angle is established by the midline and the segment that runs from the rostral end of the premaxillomaxillary suture to the caudal extreme of the nasal process of the premaxilla). This angle is $10^{\circ}$ in Diplodocus (Marsh, 1878), 40 in Camarasaurus Cope, 1877 (Madsen et al., 1995: fig. 5C; Wilson and Sereno, 1998: fig. 7C), 30 in Brachiosaurus Rigg, 1903 (Upchurch, 1999: fig. 7), $18^{\circ}$ in Nemegtosaurus, $14^{\circ}$ in Rapetosaurus (Curry Rogers and Forster, 2004: fig. 1), and approximately $35^{\circ}$ in an indeterminate 


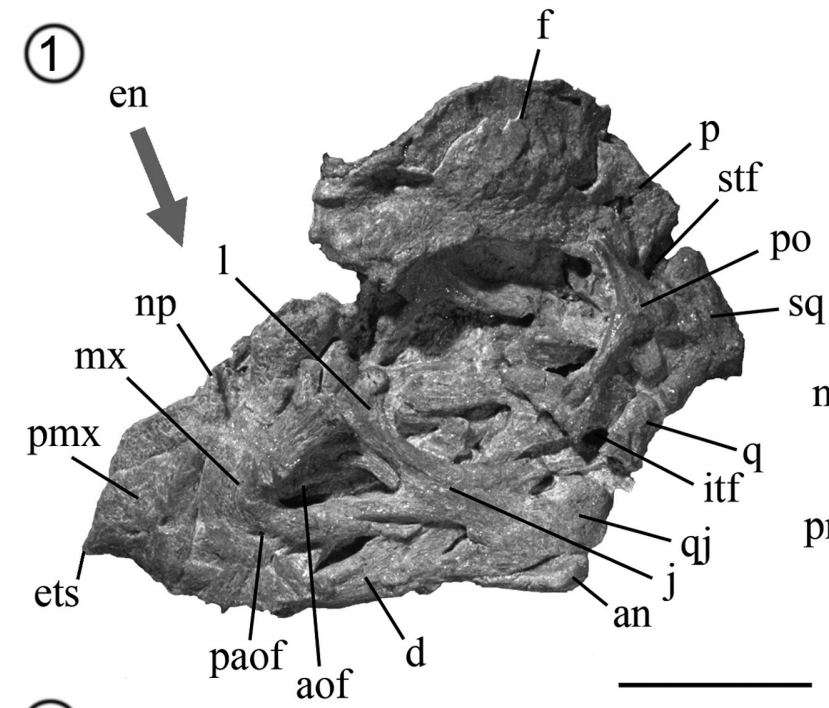

(3)
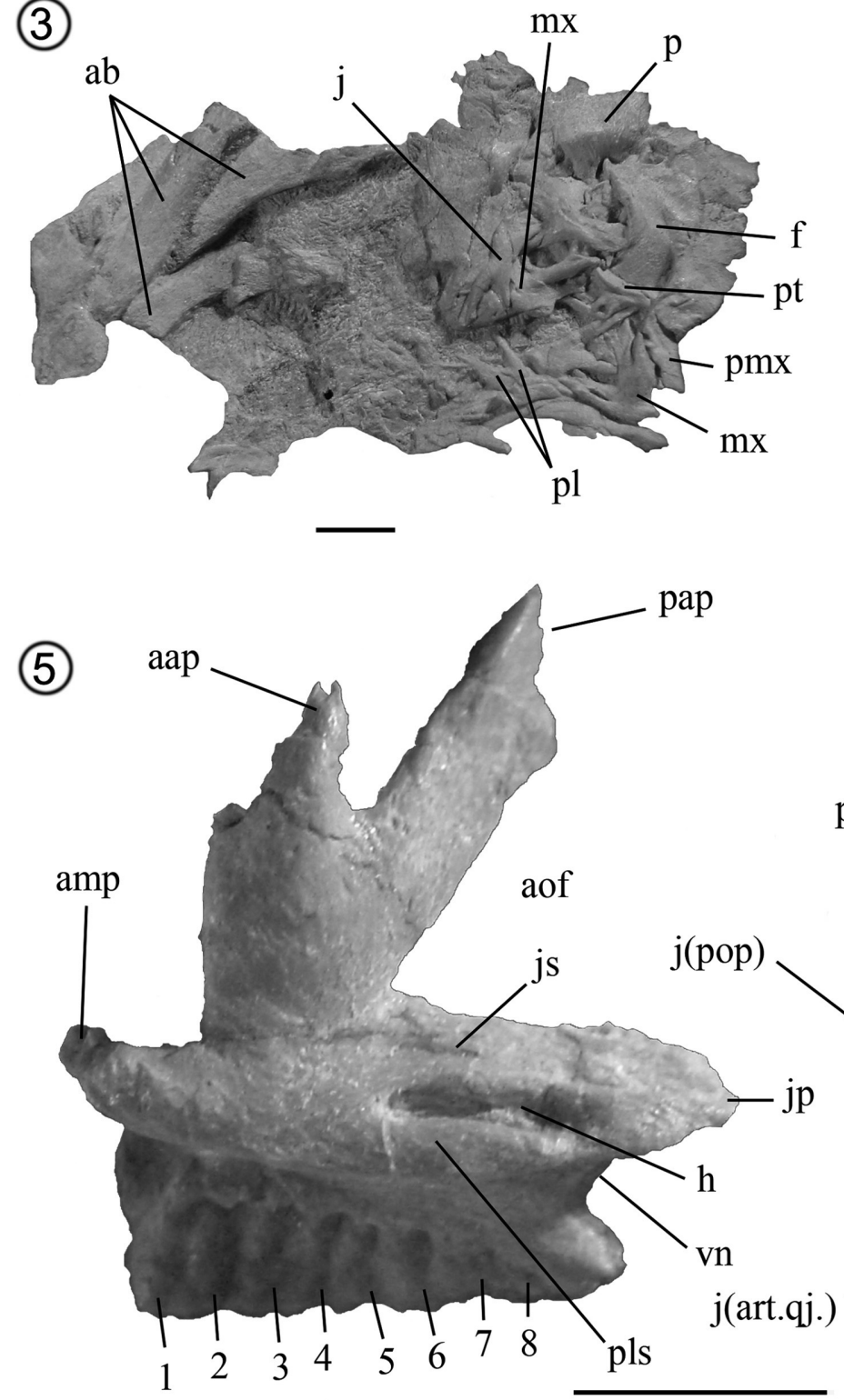
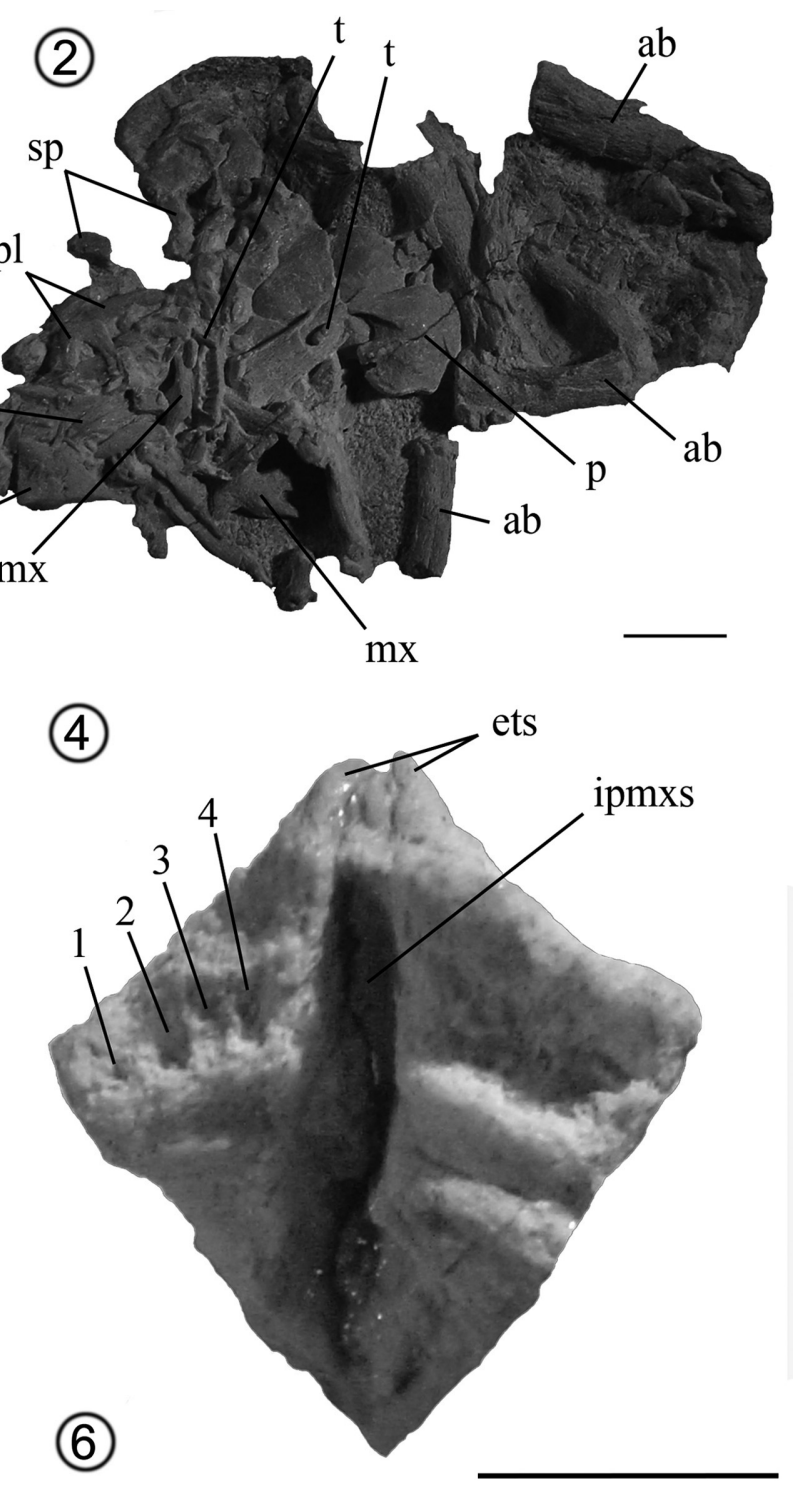

(4)

(6)

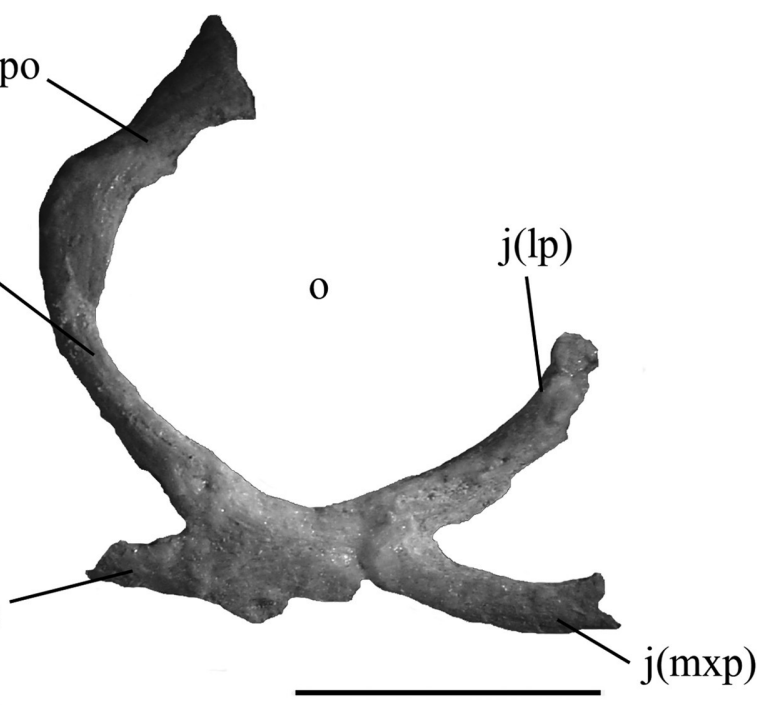


titanosaur (MPCA-Pv 74) from the Upper Cretaceous of Río Negro (Coria and Chiappe, 2001). The embryos from Neuquén show a condition that resembles that of Camarasaurus, with an angle of approximately $40^{\circ}$. Their premaxillae are wide, and would have occupied most of the snout (the maxillae would have not been exposed in anterior view), a condition unknown in adult titanosaurs. Therefore, the rostral expression of the premaxillae would have been reduced along ontogeny, and the angle between the sagittal plane and the premaxillo-maxillary symphysis (García et al., 2010) would have been either slightly or markedly reduced, according to the variability observed in adult titanosaur skulls.

According to García (2007a), the ontogenetic disappearance of the 'egg-tooth'-like structure (as a consequence of the morphological remodeling of the premaxillae), would have affected the whole anterior portion of the skull. As noted above, the ontogenetic narrowing of the premaxillae would have been accompanied by the rostral expansion of the main body of the maxillae. Thus, the maxillae would have had a greater participation of the frontal plane of the snout, reaching the condition observed in adult titanosaurs, such as Nemegtosaurus (Nowinski, 1971; Upchurch, 1999; Wilson, 2005b) and Tapuiasaurus (Zaher et al., 2011).

On the other hand, the premaxillae of the specimens from Auca Mahuevo have extremely short nasal processes (Fig. 4.1), contrary to those of adult titanosaurs (e.g., Nemegtosaurus and Rapetosaurus) and diplodocoids (e.g., Diplodocus and Apatosaurus Marsh, 1877a). This is coherent with the position of the external nares inferred for the neuquenian fossils (not completely retracted, see below). Thus, it is possible that the remodeling of the premaxillae during ontogeny implicated the elongation of the nasal process as well, which in turn would be related to the ontogenetic retraction of the external nares (Fig. 5).

\section{Retraction of the external nares (and correlated changes).}

Wilson (2002) interpreted his character 8, "external nares retracted to level of the orbits", as synapomorphic for Eusauropoda. This author proposed three states for the character "position of the external nares": (0) terminal, present in prosauropods and theropods; (1) retracted to the level of the orbits, present in all eusauropods except diplodocids; (2) retracted and located between the orbits, only in Diplodocus and Apatosaurus. Salgado and Calvo (1997) claimed, based on a premaxilla from the Los Blanquitos Formation, Salta Province (Powell, 1979), and on the premaxilla of Malawisaurus dixeyi Haughton, 1928 (Jacobs et al., 1993), that the external nares of the titanosaurs would not have been completely retracted. A similar condition is inferred from premaxilla and maxilla of neuquenian titanosaur, $\mathrm{Na}$ rambuenatitan palomoi Fillippi et al., 2011. In contrast, Curry Rogers and Forster $(2001,2004)$ interpreted that the external nares of the titanosaur Rapetosaurus krausei were retracted as in diplodocids.

In the Auca Mahuevo embryos the external nares would have been located rostro-dorsally to the antorbital fenestra and in a more rostral position (less retracted) than in $\mathrm{Ca}$ marasaurus and Malawisaurus (Jacobs et al., 1993). This is inferred, as mentioned above, from the strong rostro-dorsal inclination of the lacrimal, the rostral extension of the frontal, the relative location of the nasal, and the brevity of the nasal process of the premaxilla (Fig. 4.1, arrow). Regardless of the condition in the adults (partially or completely retracted external nares), it is evident that the external nares of the titanosaur from Auca Mahuevo migrated caudodorsally during ontogeny (García, 2008; García et al., 2010). Accordingly, the migration of the external nares

Figure 4. Titanosaur embryonic specimens from Auca Mahuevo. 1, complete and articulated skull (MCF-PVPH 263), in left lateral view. The arrow shows the inferred location of the external nares; 2, complete and disarticulated skull (MCF-PVPH 250); 3, complete and disarticulated skull (MCF-PVPH 664); 4, both articulated premaxillae (MCF-PVPH 659) in ventral view; 5, right maxilla (MCF-PVPH 679), in medial view; 6, right jugal and postorbital (MCF-PVPH 663), in lateral view. Abbreviations: 1-8, alveoli; aap, anterior ascending process of the maxilla; ab, appendicular bone; amp, anteromedial process of the maxilla; an, angular; aof, antorbital fenestra; $d$, dentary; en, external nares; ets, 'egg-tooth' structure; f, frontal; h, hole; ipmxs, interpremaxillary symphysis; itf, infratemporal fenestra; j, jugal; jp, jugal process of the maxilla; js, jugal shelf; j(art.qj.), jugal, articulation for the quadratojugal; j(lp), jugal, lacrimal process; j(mxp), jugal, maxillary process; j(pop), jugal, postorbitary process; l, lacrimal; mx, maxilla; $n$, nasal; np, narial process of the premaxilla; $\mathbf{o}$, orbit; $\mathrm{p}$, parietal; paof, preantorbital fenestra; pap, posterior ascending process of the maxilla; pl, palatine; pls, palatine shelf; pmx, premaxilla; po, postorbital; pt, pterygoid; q, quadrate; qj, quadratojugal; sp, sclerotic plates; sq, squamosal; stf, supratemporal fenestra; $t$, tooth; vn, ventral notch. Scale bars $1-3,6=1 \mathrm{~cm} ; \mathbf{4 - 5}=5 \mathrm{~mm}$. 
Embryo

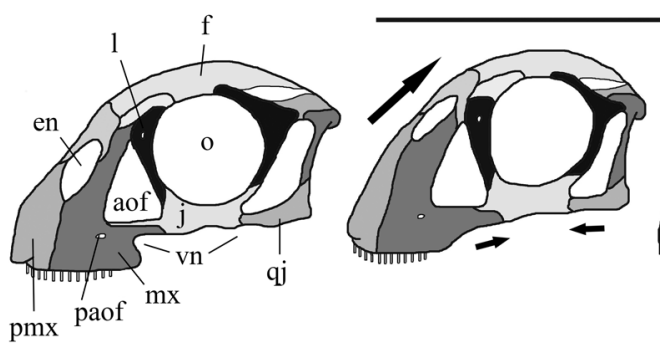

Hypothetical steps

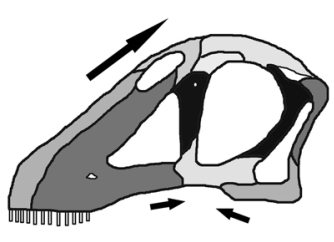

Adult

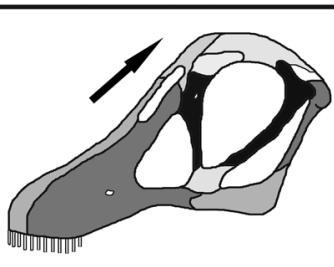

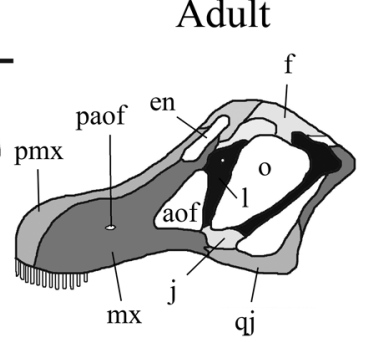

Figure 5. Ontogenetic variation in titanosaurian skull morphology. The embryonic skull at the left is based on the best preserved embryonic skulls from Auca Mahuevo (MCF-PVPH 263 and 272), the adult skull morphology at right is mostly based in Nemegtosaurus mongoliensis. The three intermediate steps are hypothetical. Larger arrow indicates the probable ontogenetic trajectory of the external nares; the smaller arrows indicate the probable ontigenetic shortening of the infraorbitary region of the skull. Abbreviations: aof, antorbital fenestra; en, external nares; $f$, frontal; j, jugal; I, lacrimal; mx, maxilla; o, orbit; paof, preantorbital fenestra; pmx, premaxilla; qj, quadratojugal; vn, ventral notch. Not to scale.

would have been correlated with the caudo-dorsal elongation of the nasal process of the premaxilla, the caudoventral inclination of the posterior ascending process of the maxilla, the caudo-dorsal rotation of the lacrimal, and, probably, the shortening of the pos-torbitary and supratemporal regions (frontal and parietal) (Fig. 5). The migration of the external nares has not been reported in other sauropods. In the youngest diplodocid known, for instance, the external nares occupy a position very similar to that one in adult specimens (Whitlock et al., 2010). The paleobiological implication of this ontogenetic variation is still unknown.

Changes in dentition. The dental formula of the Auca Mahuevo embryos is Pm4 M7-8/D10?. The number of teeth in the premaxilla and maxilla is similar to that of some adult titanosaurs, such as the Patagonian titanosaurid MAUPv-AC-01 (Coria and Salgado, 1999), Narambuenatitan (Filippi et al., 2011), Nemegtosaurus (Nowinski, 1971; Wilson, 2005b), and Rapetosaurus krausei (Curry Rogers and Forster, 2001, 2004). The titanosaur Tapuiasaurus, instead, has more teeth (reaching at least 12 in the maxilla; see Zaher et al., 2011: fig. 1). Given the variability in the tooth count among titanosaurs and the absence of complete ontogenetic sequences for all the above mentioned titanosaurs, it cannot be determined if the number of teeth remained constant in the adult forms of the Auca Mahuevo embryos. However, the low tooth count in all titanosaurs with known skulls or dentition (except for Tapuiasaurus) and the Auca Mahuevo embryos may indicate the tooth count was relatively constant along the ontogeny of titanosaurs. This contrasts with the condition of other dinosaur taxa, such as the ornithischian Hipacrosaurus Brown, 1913, and the theropod Allosaurus Marsh, 1877b, in which the number of teeth increases during ontogeny (Horner and Currie, 1994; Rauhut and Fechner, 2005).

In mature titanosaur specimens (e.g., Nemegtosaurus, Tapuiasaurus, etc.), unlike the condition in the neuquenian embryos, the caudal portion of the maxilla (which is placed ventrally to the antorbital fenestra) carries no teeth (García and Cerda, 2010a). In Rapetosaurus, according to Curry Rogers and Forster (2001), the antorbital fenestra is apomorphically expanded into the main body of the maxilla; in this way, the portion of this bone below the antorbital fenestra has teeth. Similarly, in juvenile specimens of Diplodocus the tooth row extends farther more posteriorly than in adults (Withlock et al., 2010).

The general morphology of the individual teeth is similar among adult titanosaurs with known skulls (e.g., Nemegtosaurus, Tapuiasaurus, Rapetosaurus) and these narrowcrowned teeth are also present in the Auca Mahuevo embryos, suggesting that the type of teeth did not vary along ontogeny. The exception is the absence, in prenatal stages, of wear facets (Fig. 6.1) that would be generated once the animal begins chewing movements and by the relatively thicker enamel layer of the embryonic teeth (García and Cerda, 2010a) (Fig. 6.2). The later embryonic stages, at least in the titanosaurs from Auca Mahuevo (Chiappe et al., 1998, 2001), are characterized by the presence of teeth, both 
(1)

(3)
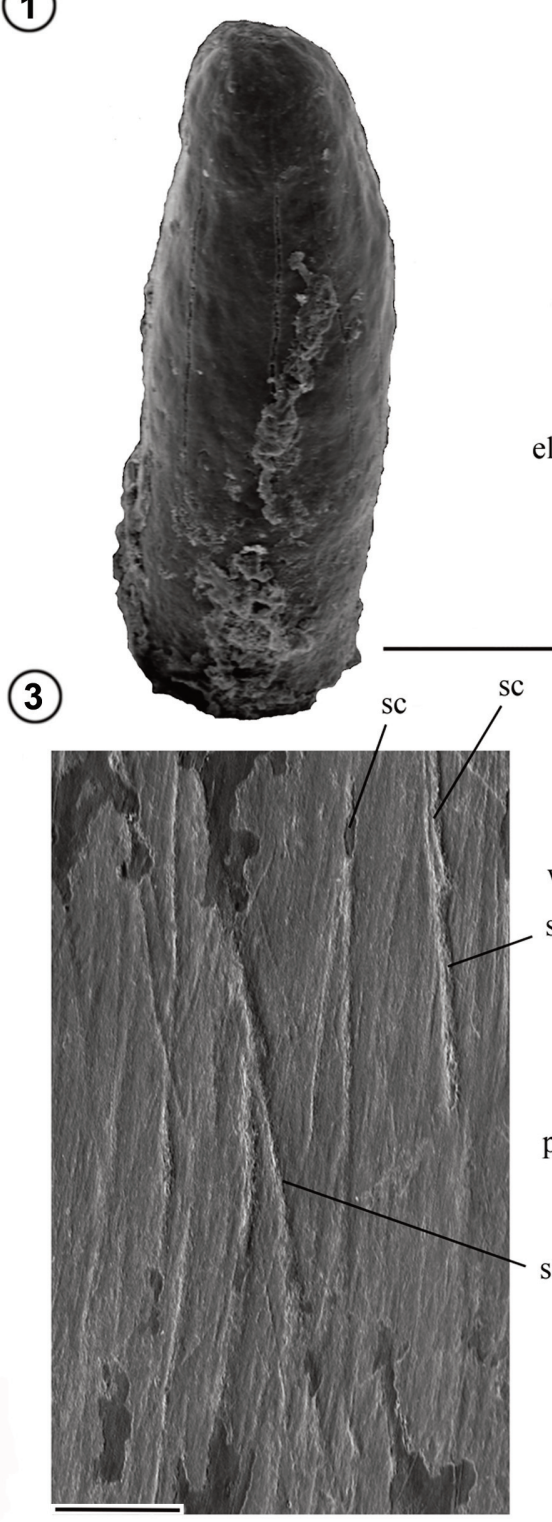

sc

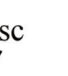

(2)
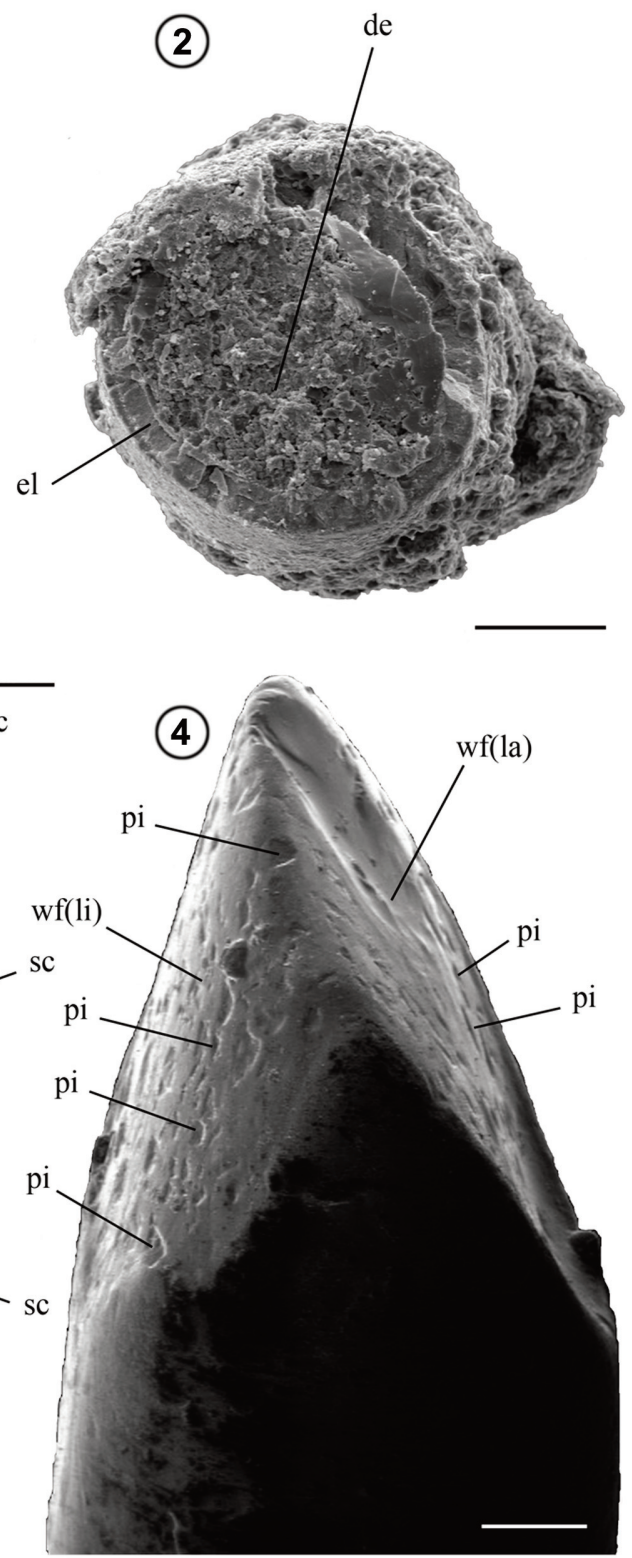

(4)

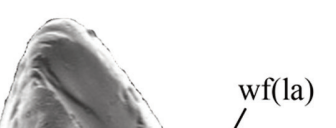

pi

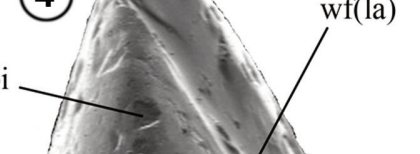

wf(li)

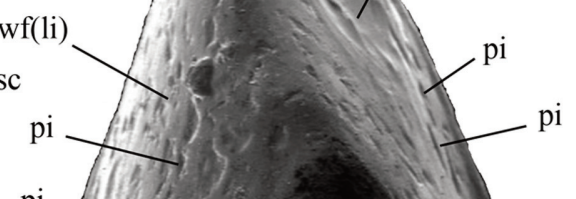

Figure 6. Titanosaurian teeth. 1, embryonic tooth (MCF-PVPH 770), showing the absence of wear facets; 2 , transverse section of an embryonic tooth (MCF-PVPH 769) showing the thickness of the enamel and dentine layers; 3 , wear facet surface of an adult titanosaurian tooth (MPCAPv 18), showing fine scratches, which are parallel to the longitudinal axis of the wear facet; 4, adult titanosaurian tooth (MPCA-Pv 203) in mesial view, showing typical double wear facet. Abbreviations: de, dentine; el, enamel; la, labial; li, lingual; pi, pits; sc, scratches; wf(la), labial wear facet; wf(li), lingual wear facet. Scale bars $1-2=0.1 \mathrm{~mm} ; 3=200 \mu \mathrm{m} ; \mathbf{4}=1 \mathrm{~mm}$.

functional (only in postnatal stages) and replacement teeth (García, 2007a).

\section{TITANOSAUR DENTITION}

Titanosaurs, as other sauropods, have four functional premaxillary teeth (Nowinski, 1971; Coria and Chiappe, 2001), seven to eight in the maxilla (Sciutto and Martínez, 1994; García and Cerda, 2010a), and 11-14 in the dentary
(Nowinski, 1971; García, 2008; García and Cerda, 2010a; Machado et al., 2013). The teeth are basically cylindrical, with their margins nearly parallel, without denticles and tapering distally (Fig. 6.1-4). In cross section, titanosaur teeth vary from circular to elliptical and some are gently 'D'-shaped (Wilson and Sereno, 1998) (Fig. 6.2). Most frequently the labial side is slightly convex and the lingual one is slightly concave, although in numerous specimens the 
latter is more or less straight (Kues et al., 1980; Kellner, 1996; Upchurch et al., 2004). These curvatures, together with the different morphologies and positions of the wear facets, enable the identification of isolated teeth from the upper (premaxillary or maxillary) and lower dentition (dentary) (García and Cerda, 2010b).

Functional teeth of titanosaurs normally bear wear facets (Fig. 6.4). García and Cerda (2010b) proposed a classification for titanosaur tooth-wear based on shape and distribution of those facets. It includes: (1) teeth with a single wear facet, on either lingual or labial faces; (2) teeth with a pair of wear facets, one on the labial and the other on the lingual face (Fig. 6.4); and (3) teeth with multiple, complex wear facets (García and Cerda, 2010b: fig. 5).

Adult titanosaurs presumably had, in addition to the functional tooth, three replacement teeth per alveolus in premaxillae and maxillae (Coria and Chiappe, 2001; Zaher et al., 2011; D'Emic et al., 2013), and two in the dentary (García and Cerda, 2010b; Gallina and Apesteguía, 2011; Machado et al., 2013). As we know, sauropods replaced their teeth throughout their lives (Huene, 1929; Nowinski, 1971; Powell, 1979; Coria and Chiappe, 2001). In nearly all sauropods, this replacement is produced in a linguo-labial direction, from the most immature to the most functional, with the replaced tooth being the most labially positioned in the alveolus. In the dentary, the style of dental replacement was first studied by Nowinski (1971) in Nemegtosaurus mongoliensis, by García and Cerda (2010b) in a fragment of a Titanosauria indet., by Gallina and Apesteguía (2011) in Bonitasaura salgadoi Apesteguía, 2004b, and by Machado et al. (2013) in the Brazilian titanosaur Brasilotitan nemophagus Machado et al., 2013. In some of these cases, the pattern of replacement is in 'waves', similar to that recorded in other non-mammalian tetrapods (Edmund, 1960; Osborn, 1977).

Micro-wear marks are frequently found on the wear facets (Fig. 6.3-4); these have been used by different authors to infer diet preferences (Fiorillo, 1991, 1997, 1998, 2008; Calvo, 1994; Upchurch and Barrett, 2000; Schubert and Ungar, 2005; Sereno et al., 2007; García and Cerda, 2010b; Whitlock, 2011; Díez Días et al., 2012; García, 2013). Some of these authors observed, in numerous teeth of indeterminate titanosaurs, fine striations or scratches, parallel and sub-parallel to the greater axis of the wear facet, as well as pits, both in wear facets (dentine and enamel) and on the rest of the tooth surface (on the enamel) (Fig. 6.3). Although García and Cerda (2010b) agree that wear facets would have originated by tooth-to-plant matter or tooth-to-tooth contact because of constant friction, they concluded that the micro-wear would be related to the amount and attributes of the (involuntarily swallowed) rocky material (sediment grains, sand, etc.), mixed with the food (García, 2013). The above summarized dental features of titanosaurs provide important clues for interpreting dietary and functional aspects of titanosaur paleobiology (see Discussion).

\section{TITANOSAUR HISTOLOGY}

Bone histology provides information about the biology of extinct vertebrates, and has been used extensively for dinosaurs (Chinsamy-Turan, 2005). Bone microstructure provides a direct record of ontogenetic growth and gives clues on various aspects of dinosaur biology, including growth rates, longevity, age at maturity, adult size, ontogenetic stages, and timing of sexual maturity (Chinsamy-Turan, 2005).

There is a significant number of contributions that deal with the long-bone histology of sauropods (Rimblot-Baly et al., 1995; Curry, 1999; Sander, 2000; Sander et al., 2004, 2006, 2011; Klein and Sander, 2008; Klein et al., 2009, 2012; Woodward and Lehman, 2009; Company, 2011; Stein et al., 2010). However, studies on bone histology of titanosaur sauropods have just begun during the past few years. Regarding the non-South American titanosaurs, published histological descriptions include: Phuwiangosaurus sirindhornae Martin et al., 1994 (Klein et al., 2009), Alamosaurus sanjuanensis Gilmore, 1922 (Woodward and Lehman, 2009), Lirainosaurus astibiae Sanz, Powell, Le Loeuff, Martínez and Pereda-Suberbiola, 1999 (Company, 2011), Magyarosaurus dacus Nopcsa, 1915 (Stein et al., 2010) and Ampelosaurus atacis Le Loeuff, 1995 (Klein and Sander, 2008, Klein et al., 2012). In general terms, the primary cortical bone of these taxa is mainly composed of fibro-lamellar tissue and/or parallel-fibered bone tissue. A particular primary bone tissue, namely Modified Laminar Bone (MLB) has been reported in some taxa, including Ampelosaurus, Magyarosaurus Huene, 1932, Phuwiangosaurus Martin, Buffetaut and Suteethorn, 1994, and Lirainosaurus (Klein et al., 2012). In this particular bone tissue the scaffolding of the fibrolamellar 

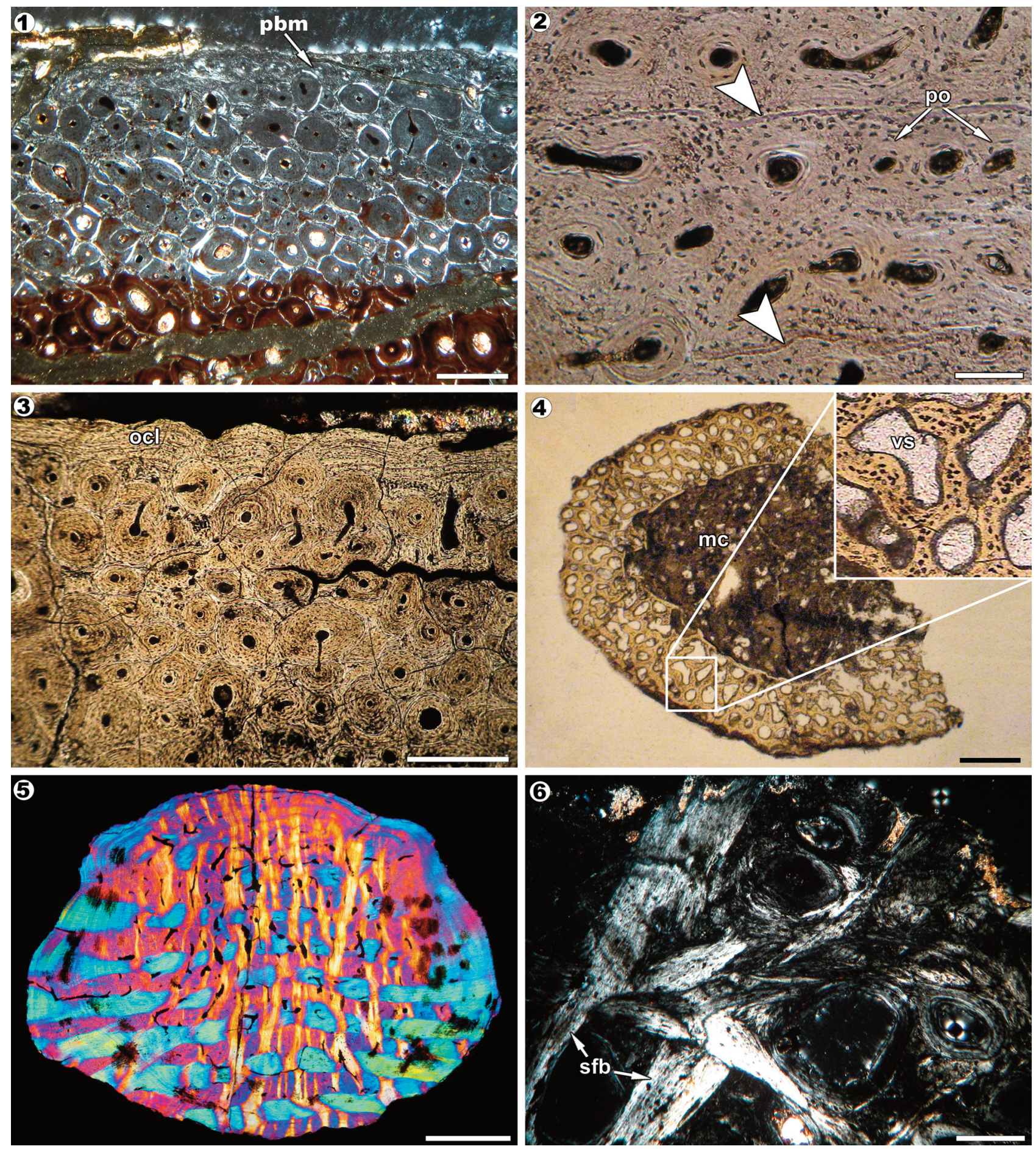

Figure 7. Bone histology of South American titanosaurs. 1, Dense Haversian tissue of the outer cortex of the mid diaphysis of a tibia of a nonfully developed specimen of Neuquensaurus australis (MLP CS 1093). Note that the primary bone tissue has been almost entirely replaced by secondary bone; 2 , detail of the primary bone tissue in the mid shaft of a femur of a non-fully developed specimen of Neuquensaurus australis (MCS-Pv 5/28, femur length: $85 \mathrm{~cm}$ ). Arrowheads indicate the presence of LAGs; 3, external cortex of the mid diaphysis of a humerus of Neuquensaurus robustus (MCS-Pv 8, femur length: $81 \mathrm{~cm}$ ). The bone tissue is composed by dense Haversian bone. A well-developed EFS is observable in the subperiosteal cortex; 4 , transverse section of a long bone of the embryo of an indeterminate titanosaur from Auca Mahuevo locality (MCF-PVPH 808). Upper right corner: detailed view of the embryonic bone tissue; 5, dermal ossicle of Saltasaurus loricatus. Note the vertical and horizontal system of structural fiber bundles; 6 , structural fiber bundles in the osteoderm of an indeterminate titanosaur. 1 and 6, polarized light; 2-4, normal transmitted light; 5, polarized light with lambda compensator. Abbreviations: efs, external fundamental system; mc, marrow cavity; pbm, primary bone matrix; po, primary osteons; sfb, structural fiber bundles; vs, vascular space. Scale bars 1, 3-4, 6= 0.5 mm; $2=0.1 \mathrm{~mm} ; 5=1 \mathrm{~mm}$. 
bone - which usually is laid down as a matrix of woven bone- is laid down as parallel-fibered or lamellar bone matrix instead (Klein et al., 2012). Klein et al. (2012) suggested that MLB is a general feature of small titanosaurs. Regarding growth marks, growth cycles in the form of modulations were observed only in Alamosaurus (Woodward and Lehman, 2009). Other kinds of growth marks (lines of arrested growth or LAGs) have been reported in Lirainosaurus, Magyarosaurus, and Phuwiangosaurus. The high degree of secondary remodelling is noteworthy in several of the published taxa (Klein et al., 2009, 2012; Stein et al., 2010; Company, 2011).

Although the record of titanosaurs in South America is specially abundant and diverse, studies focused on their bone histology are very scarce. To date, the only published contribution in this regard is based on the study of the holotype of Bonitasaura salgadoi (Gallina, 2012). Preliminary histological descriptions of Mendozasaurus neguyelap González Riga, 2003, Saltasaurus loricatus Bonaparte and Powell, 1980, and Neuquensaurus Powell, 1992, have been carried out recently (González Riga and Curry Rogers, 2006; Cerda and Powell, 2009; Cerda and Salgado, 2011). From these contributions, some generalized features can be mentioned. As reported for other titanosaurs (e.g., Lirainosaurus), dense Haversian tissue predominates in most of the examined samples and the amount of primary tissue is much reduced and limited to the outer cortex (Fig. 7.1). Typologically, the primary tissue is mostly fibro-lamellar, with variable amounts of parallel-fibered bone. The primary bone matrix is commonly interrupted by growth marks (LAGs and/or annuli) (Fig. 7.2). The outer layer of avascular or poorly vascularized bone tissue that indicates that maximum body size and skeletal maturity of an individual are attained (External Fundamental System or EFS) could be established only in Saltasaurus and Neuquensaurus (Fig. 7.3; see also Cerda and Powell, 2009; Cerda and Salgado, 2011).

The exceptional bone remodelling observed in South American titanosaurs is in accordance with previous descriptions of small-bodied titanosaurs (Klein et al., 2009, 2012; Stein et al., 2010; Company, 2011). Although the causes of extreme remodelling of the primary bone have not been explored yet in depth, it is hardly a size-related characteristic, because the secondary remodelling in non-titanosaurian taxa (e.g., Dicraeosaurus Janensch, 1914) of a comparable size is less than that recorded in small titanosaurs such as Ampelosaurus (Klein et al., 2012: fig. 1). Other possible explanation could be related with the particular posture and locomotion of titanosaurs (D'Emic and Wilson, 2012). The causes alleged for secondary remodelling in vertebrates (many of which are based on experimental evidence) are diverse (Enlow, 1962; Currey, 2003), and the causal origin of the Haversian tissue is still debated among neontologists; obviously, this precludes our comprehension of the unusual secondary remodelling observed in several titanosaurs.

The abundance of Haversian tissue in the cortex of the appendicular bones of several titanosaur taxa enormously hampers the observation of possible growth marks; however, these are clearly present. The repeated presence of discontinuities such as LAGs and annuli in the mid- and outer cortex of diverse appendicular bones suggests that many titanosaur species had, at least in a certain stage of their ontogeny, a discontinuous growth.

Concerning the microstructure of prenatal ontogenetic stages, García (2008) and García and Cerda (2010a) analyzed thin sections of the embryonic specimens from Auca Mahuevo. Their bone tissue is composed exclusively of woven fibered bone, with numerous and wide vascular spaces that rendering it a finely spongy appearance (Fig. 7.4). The bone microstructure of the Patagonian titanosaur embryos reveals an early stage of development, earlier than that of other dinosaurian embryonic specimens whose paleohistology is known (Horner et al., 2001; Ricqlès et al., 2001; Weishampel et al., 2008; Reisz et al., 2013).

It is clear that study of the osteohistology of South American titanosaurs is just beginning. The relative abundance of titanosaurian materials from South America provides a unique opportunity to assess several aspects of titanosaurian paleobiology (e.g., growth rates and evolution of body size) and a more complete understanding of these aspects awaits a comprehensive taxon sampling of the South American forms.

On the other hand, microstucture of the titanosaur osteoderms is poorly known. In his study of the bony plates from the Upper Cretaceous of northern Patagonia, Salgado $(2000,2003)$ described the histology of an element belonging to an indeterminate titanosaur from the Allen Formation. This bone is characterized by being compact, with an outer fibrous primary tissue and an important 
amount of inner Haversian tissue (Salgado, 2003). Also, the bone histology of the osteoderms (bony plates and dermal ossicles) of Saltasaurus loricatus has been recently described (Cerda and Powell, 2010). Bony plates are composed of secondary spongy bone, with only a thin cortex of primary tissue. Conversely, the small dermal ossicles are compact structures composed entirely by primary bone (Fig. 7.5). The primary bone matrix of both bony plates and ossicles consists of coarse bundles of mineralized collagenous fibers (structural fibers sensu Scheyer and Sander [2004]). In a recent contribution, Curry Rogers et al. (2011) described the gross morphology and internal anatomy of two osteoderms assigned to Rapetosaurus krauseifrom the Upper Cretaceous of Madagascar. Although that contribution was not focused on osteoderm histology, the authors mention the presence of fibro-lamellar bone tissue in one of the elements. Also, they indicate the presence of an important internal cavity (more than half its total volume) in the larger osteoderm. Curry Rogers et al. (2011) interpreted this last feature as evidence for a mineral-storage function in titanosaur osteoderms. Histological observations made on bony plates assignable to Titanosauria from the Anacleto and Allen formations (Cerda et al., in press) also reveal the presence of primary tissue formed by structural fibers (Fig. 7.6). These bundles are similar to the structural fibers described in osteoderms of ankylosaurs (Scheyer and Sander, 2004) and Saltasaurus and they support the metaplastic origin for these structures.

\section{TITANOSAUR PNEUMATICITY}

The causal relationship between some osteological features and an avian-like air sac system has been recognized in sauropod dinosaurs since the mid-nineteenth century. The origin, development, variation and biological implications of postcranial skeletal pneumaticity (PSP) in sauropod dinosaurs (including titanosaurs) has been discussed in depth by several authors (Janensch, 1947; Britt, 1993; Wedel et al., 2000; Wedel, 2003, 2007, 2009; Schwarz et al., 2007a). Titanosaurian PSP has been studied in relatively few taxa, including Alamosaurus sanjuanensis (Woodward and Leehman, 2009), Malawisaurus dixeyi (Wedel, 2009; Wedel and Taylor, 2013) and saltasaurine titanosaurs (Saltasaurus, Neuquensaurus and Rocasaurus Salgado and Azpilicueta, 2000; Cerda et al., 2012). In the latter study, anatomical description of several specimens reveals that saltasaurine titanosaurs show evidence of PSP in both the axial and appendicular skeleton. Cortical foramina connected with internal cavities (namely, the most reliable evidence for PSP in fossil groups) are present along the vertebral column, including posterior caudal vertebrae (Fig. 8.1-8). In the appendicular skeleton, evidence of PSP is observed in the pelvic (ilium) and scapular (scapula and coracoid) girdles (Fig. 8.9-15).

The particular pneumatic features of the saltasaurine titanosaurs reported by Cerda et al. (2012) provided new information about the soft tissue anatomy and the structure of the respiratory system of this lineage, and also clues about the evolution of PSP in archosaurs. First, Saltasaurini show the most extreme case of PSP not only in titanosaur sauropods, but also in sauropodomorph dinosaurs, with evidence of invasion of pneumatic diverticula in the pectoral girdle and the distal portion of the tail. Second, given the strict correlations that exist between specific air sacs and the axial elements that they pneumatize in living birds (O'Connor and Claessens, 2005; O'Connor, 2006), the PSP pattern reported for Saltasaurini has been interpreted as evidence for the presence of cervical, abdominal and interclavicular airs sacs in these titanosaurs (Cerda et al., 2012). Although previous studies of PSP proposed that cervical and abdominal air sacs were actually present in sauropodomph dinosaurs (Wedel et al., 2000; Wedel, 2007, 2009; Perry et al., 2011), anatomical evidence for clavicular air sacs has been reported only in saltasaurine titanosaurs. Third, besides pterosaurs and theropod dinosaurs, extensive pneumaticity was also reached independently in Sauropodomorpha. The extreme PSP in saltasaurine titanosaurs supports the evidence of widespread, repeated evolution of appendicular and posterior axial skeletal pneumaticity in ornithodiran archosaurs, which in turn indicates that a heterogeneously partitioned pulmonary system is primitive for this group (Wedel, 2009; Perry et al., 2011; Benson et al., 2012; Butler et al., 2012; Cerda et al., 2012; Yates et al., 2012).

\section{TITANOSAUR POSTURE AND LOCOMOTION}

The analysis of the locomotion in extinct vertebrates without living representatives is one of the major challenges of paleobiological inquiries (Alexander, 1989). Indeed, direct 

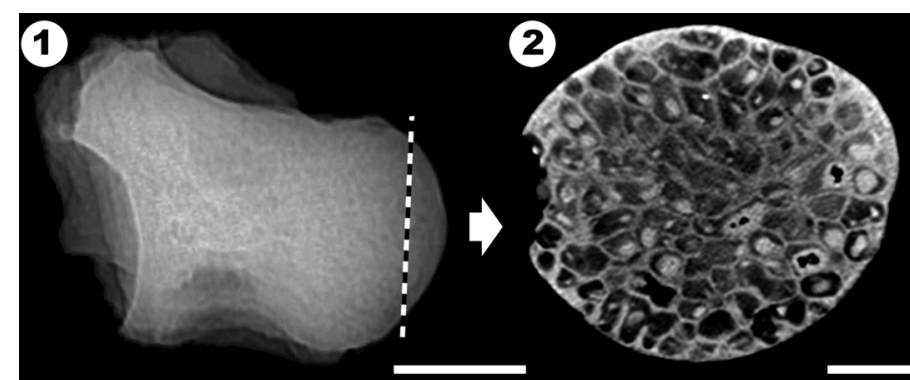

3

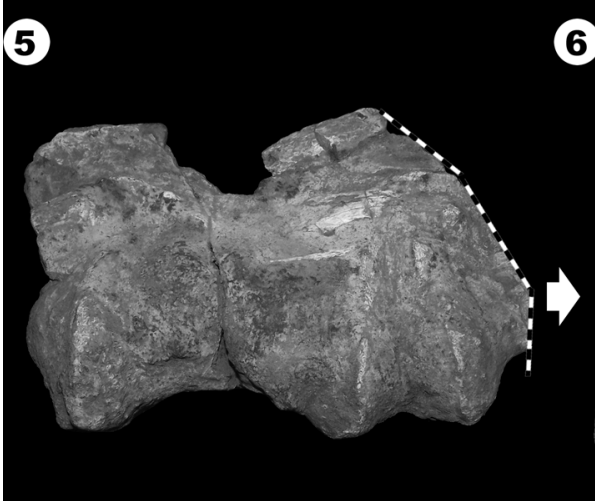

6
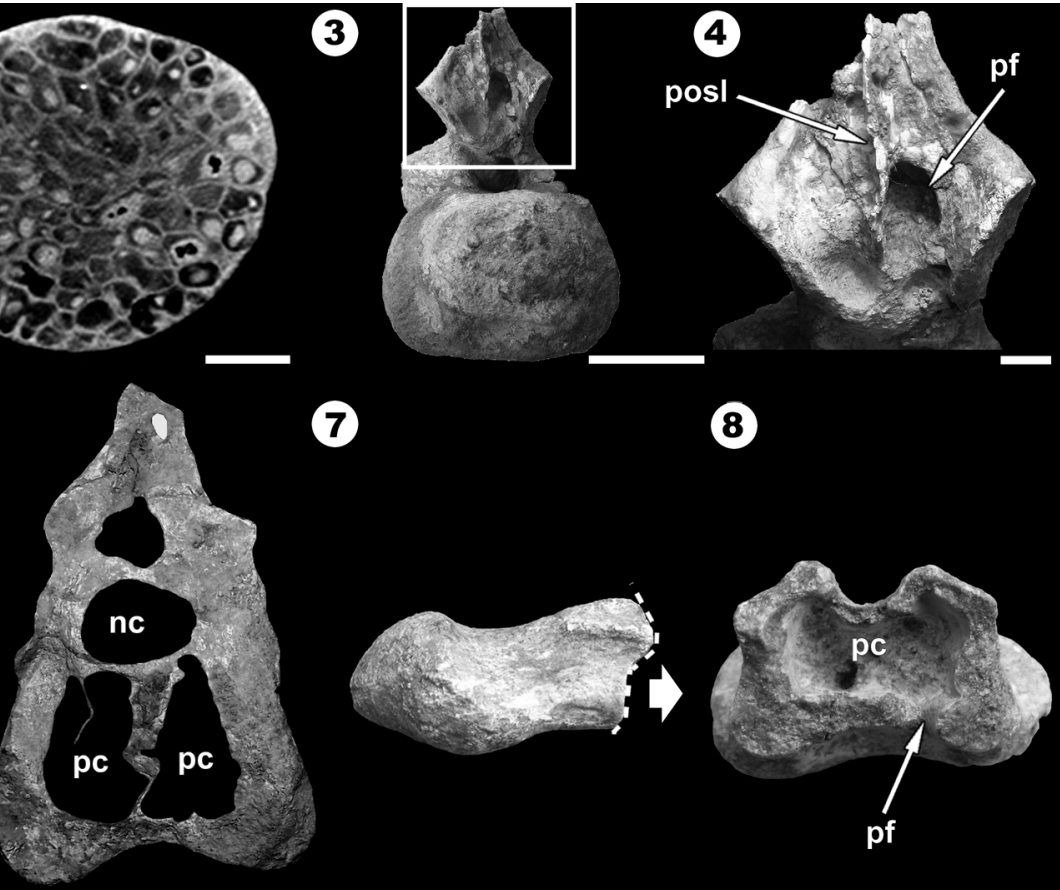

7

8
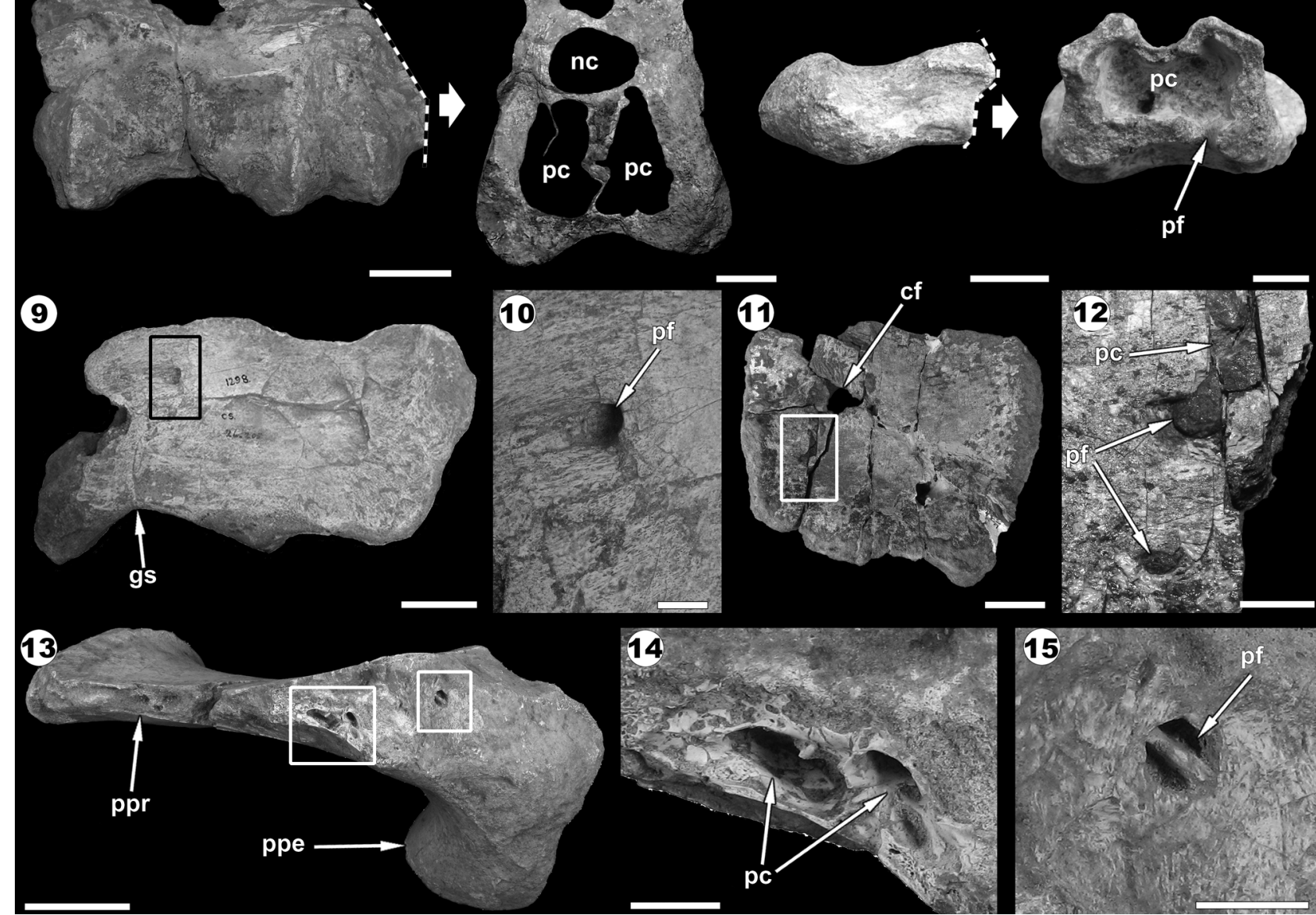

Figure 8. Pneumatic features in the caudal vertebrae and appendicular skeleton of Saltasaurini titanosaurs. 1, X-ray image of a middle caudal vertebra of Rocasaurus muniozi (MPCA-Pv 47). Dashed line indicates the section showed in 2; 2, CT scan of the same specimen showing the internal camellate bone; 3, middle caudal vertebra of Neuquensaurus australis in posterior view (MCS-Pv 5/9); 4, detail of a pneumatic foramen in the neural arch of the same specimen (box inset in 3); 5 , two articulated middle caudal vertebrae of Neuquensaurus australis (MLP Ly 82) in lateral view (inverted). Dashed line indicates the section showed in 6; 6, broken surface showing the internal pneumatic cavities. Given the poor contrast between bone tissue and sedimentary matrix, the last has been digitally erased; 7, distal caudal vertebra of Rocasaurus muniozi (MPCA-Pv 56) in lateral view. Dashed line indicates the section showed in $\mathbf{8 ;} \mathbf{8}$, broken surface showing a prominent pneumatic cavity that occupies almost the entire cross section area of the centrum. Note the presence of a pneumatic foramen in the ventral surface; 9 , fragment of scapulocoracoid of Neuquensaurus australis (MLP-CS 1298) in medial view; 10, detail of the pneumatic foramen in the medial surface (box inset in 9); 11, left coracoid of Saltasaurus loricatus (PVL 4017-101) in medial view; 12, close up of the pneumatic foramina in the same specimen (box inset in 11). Note the presence of internal camellae communicated with the larger foramen; 13, incomplete right ilium Neuquensaurus australis (MLP-CS 1057) in dorsal view; 14, broken surface of the same specimen (large box inset in 13) showing the internal camellate tissue; 15, detailed view of the same specimen (small box inset in 13) showing a well developed pneumatic foramen on the medial surface. Abbreviations: cf, coracoid foramen; gs, glenoid surface; nc, neural canal; pc, pneumatic cavities; pf, pneumatic foramen/foramina; posl, postspinal lamina; ppe, pubic peduncle; ppr, preacetabular process. Scale bars $1,3,5,9,11,13=50 \mathrm{~mm} ; 2,7=20 \mathrm{~mm} ; 4,6,8,10,12,14,15=10 \mathrm{~mm}$. 
1

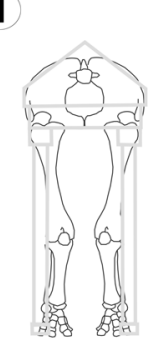

\section{2}

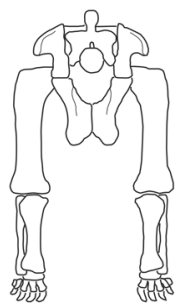

4

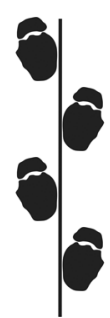

3

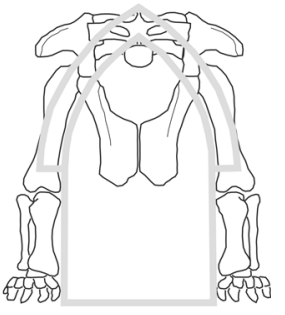

5

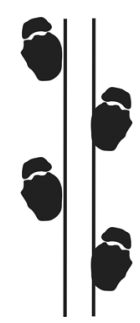

Figure 9. Reconstructed pelvic girdles and hindlimbs of 1, Loxodonta africana (with light grey Greek column model); 2, Camarasaurus; 3, the titanosaur Opisthocoelicaudia (with light grey roman arch model), in anterior view, at the level of the first sacral vertebra ( 2 and $\mathbf{3}$ from Wilson and Carrano, 1999); 4, sauropod, 'narrow-gauge' trackway; 5, sauropod 'wide-gauge' trackway (from Romano et al., 2007). Not to scale.

observation is impossible, and much of the functional and biomechanical interpretation is inferred from analogies with extant groups (Lauder, 1995). Osteology and ichnology are the only available evidences for approaching their limb kinematics (Alexander, 1989; Johnson and Ostrom, 1995; Wilson and Carrano, 1999).

Sauropod dinosaurs include the largest terrestrial animals ever known (Bonaparte and Coria, 1993; Novas et al., 2005), with body-size being a hallmark of their body-plan (Bakker, 1971; Salgado, 2000; Carrano, 2005; Sander et al., 2010). In fact, several morphological features of Sauropoda seem to be size-related, such as their quadrupedal and columnar graviportal posture (McIntosh, 1990; Upchurch, 1995; Salgado et al., 1997; Wilson and Sereno, 1998; Carrano, 2005; Wilson, 2005a).

The appendicular skeleton of titanosaurs moves away from the typical sauropod locomotory plan (Salgado et al., 1997; Wilson and Carrano, 1999; Carrano, 2005). Wilson and Carrano (1999, p. 162) proposed several attributes in the appendicular skeleton of titanosaurs, particularly in Saltasaurini, as "adaptations to mobility", since they would have increased their ability for particular movements com- pared to other sauropods. Some of the features that would increase mobility are: (1) the lateral development of the preacetabular lobes of the ilium, which aligned the lines of action of protractor muscles in an anteroposterior direction; (2) the presence of broad articular surfaces in the distal femur, which increased the range of movement of the femorotibial articulation; (3) expanded humeral distal condyles, and well-developed olecranon, which reduced the columnar posture (Wilson and Carrano, 1999; see also Bonnan, 2003).

The extreme development of these characteristics are present in Saltasaurini (sensu Salgado and Bonaparte, 2007), a distinctive clade of derived titanosaurs which also display the smallest sizes within the clade (Jianu and Weishampel, 1999; Powell, 2003), possibly due to heterochronic processes (Salgado, 1999).

Because of their overall morphological similarity and their graviportal-columnar locomotory plan, sauropods have traditionally been compared with elephants. However, the above-mentioned titanosaur features suggest that their limbs were not as columnar as in non-titanosaur sauropods or proboscideans (Wilson, 2005a) (Fig. 9.1-3). Nonetheless, the discussion on the limb posture in titanosaurs should not be reduced to fully erect (i.e., elephantine posture) vs. sprawling posture (i.e., typical reptilian posture). The debate should turn on the question of whether the limbs always acted in a fully parasagittal way (as is supposed to be in non-titanosaur sauropods) or whether they employed another repertoire of postures, such as the potentially upright posture or tripodal stance for feeding, copulation, and defense (Huene, 1929; Borsuk-Bialynicka, 1977; Bakker, 1978; Alexander, 1985; Wilson and Carrano, 1999; Powell, 2003).

\section{Trackway evidence and girdle architecture}

Trackways have provided good evidence for reconstructing limb posture in extinct animals (Wilson and Carrano, 1999; Paul and Christiansen, 2000). Sauropod trackways vary between a continuum of two major categories: 'narrow-gauged' (produced by non-titanosaurian sauropods), where manus and pes impressions are close to or even on the trackway midline, and 'wide-gauged' (produced by titanosaurian sauropods), in which the impressions are well separated from the trackway midline (Farlow, 
(1)

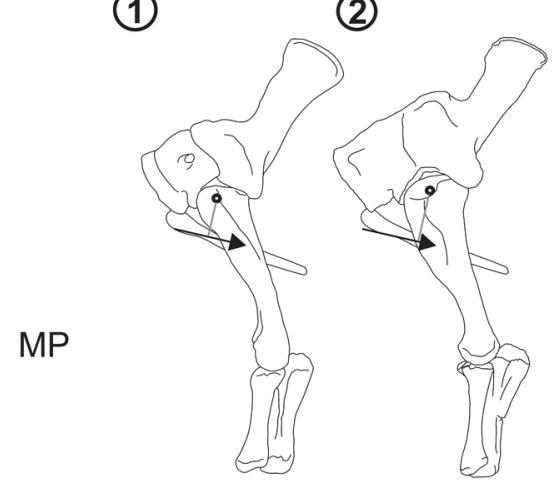

(2)

(3)

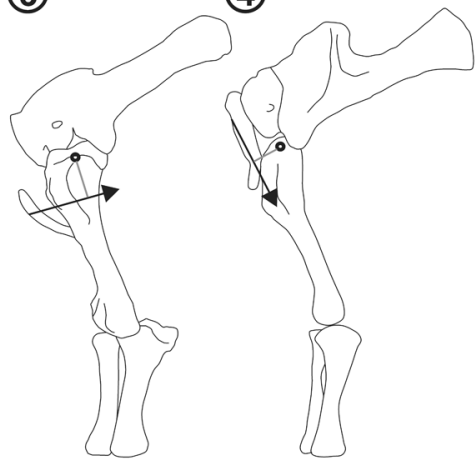

(4)

(5)

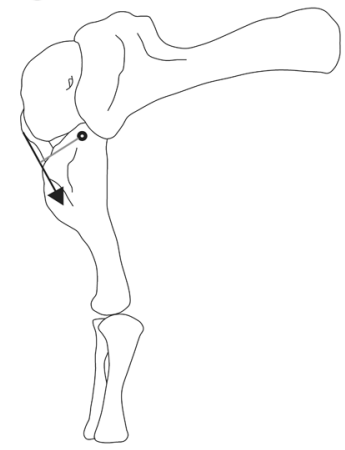

(6)
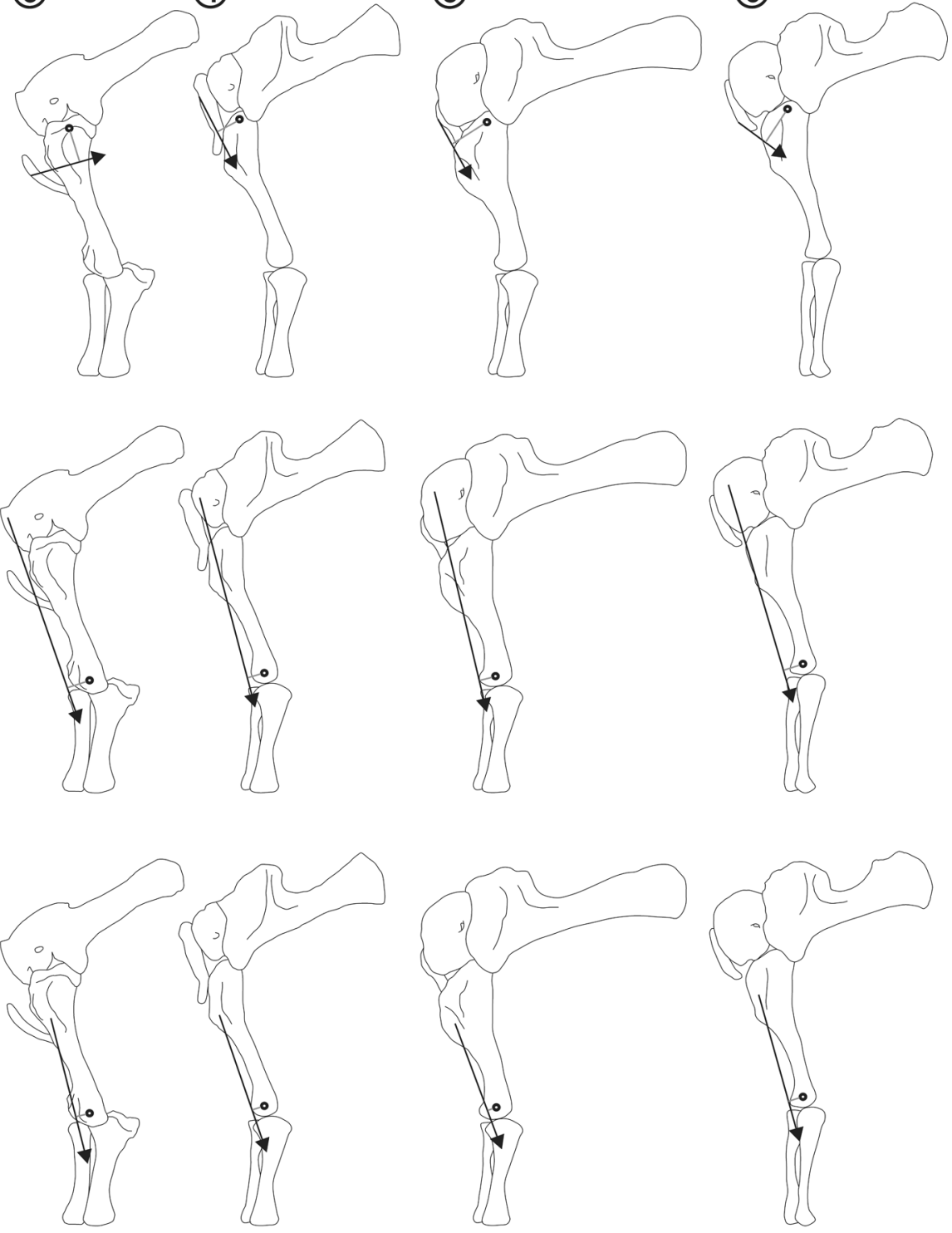

Figure 10. Lines of action and moment arms for the muscles pectoralis (MP), brachialis (MB), and humeroradialis (MH) in 1, Saltasaurus; 2, Neuquensaurus; 3, Opisthocoelicaudia; 4, Diplodocus; 5, Apatosaurus; 6, Camarasaurus. 3, based on Borsuk-Bialynicka (1977); 4-6, based on Wilhite (2003). Not to scale.

1992; Wilson and Carrano, 1999; Romano et al., 2007). Despite the continuous variation of the sauropod trackway gauge, recent works have defined three categories of track gauge, based on the trackway ratio, which can be applied to all dinosaurian tracks: 'wide-, medium-, and narrow-gauge' (Romano et al., 2007). To explain the trackway pattern of these graviportal animals in functional terms we must analyze the architecture of girdles and limbs in a stance position.

Regarding the scapular girdle, Wilson and Carrano
(1999) stated, among others features, the presence of a prominent olecranon and elongated sternal plates as features suggesting a more flexed resting pose than in non-titanosaur sauropods, generating a 'wide-gauged' trackway pattern. But how could these features contribute to such flexed resting pose? The architecture of the scapular girdle and the analysis of muscle lines of action and moment arms shed light on this topic. The methodology of estimating muscle moment arms is specified in the Supplementary Online Information. 
(1)

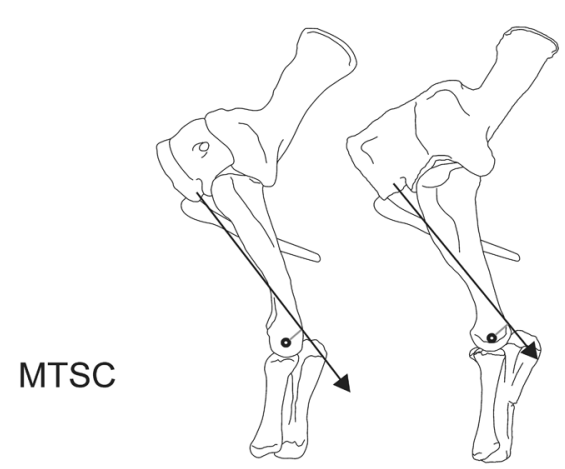

(2)

(3)

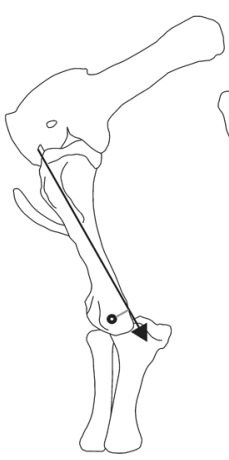

(4)

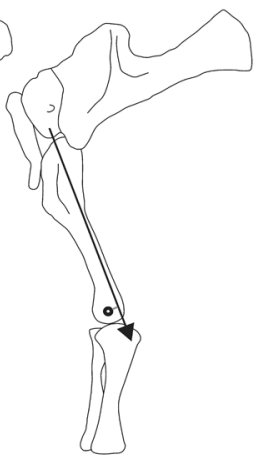

(5)
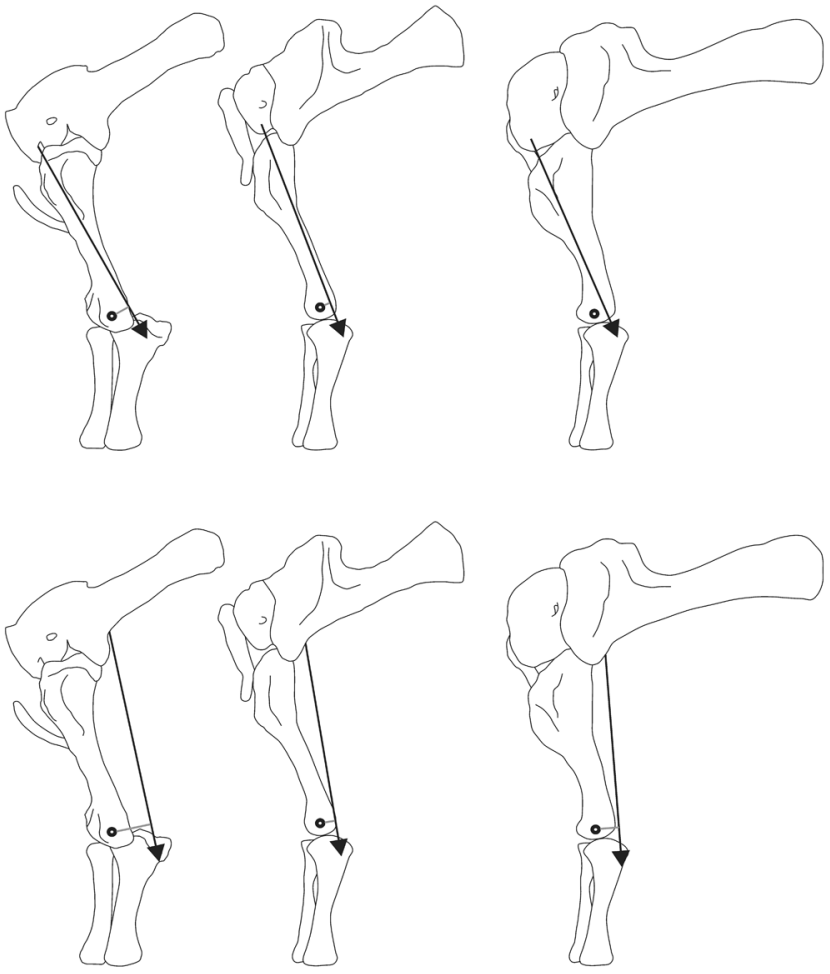

MTS
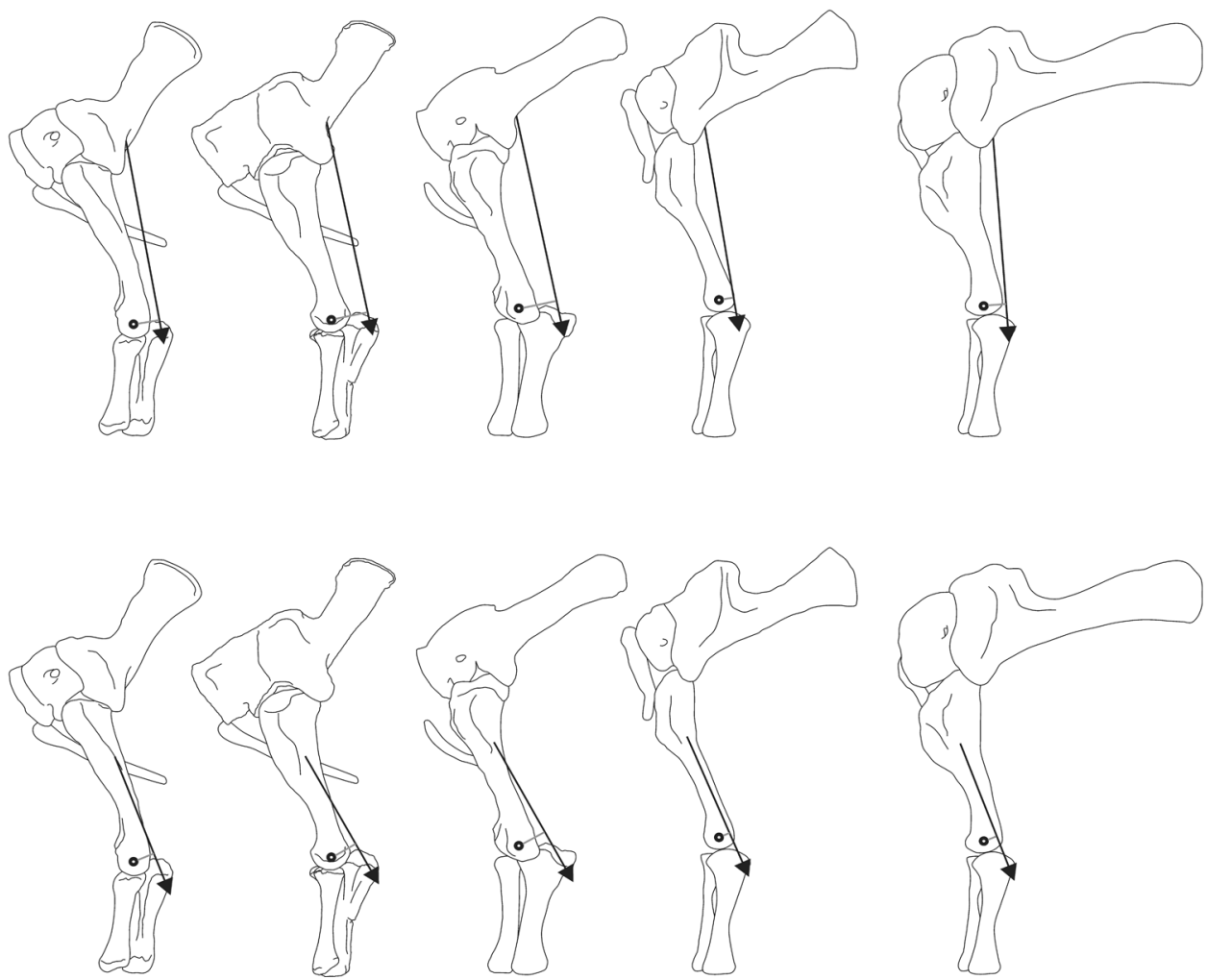

(6)
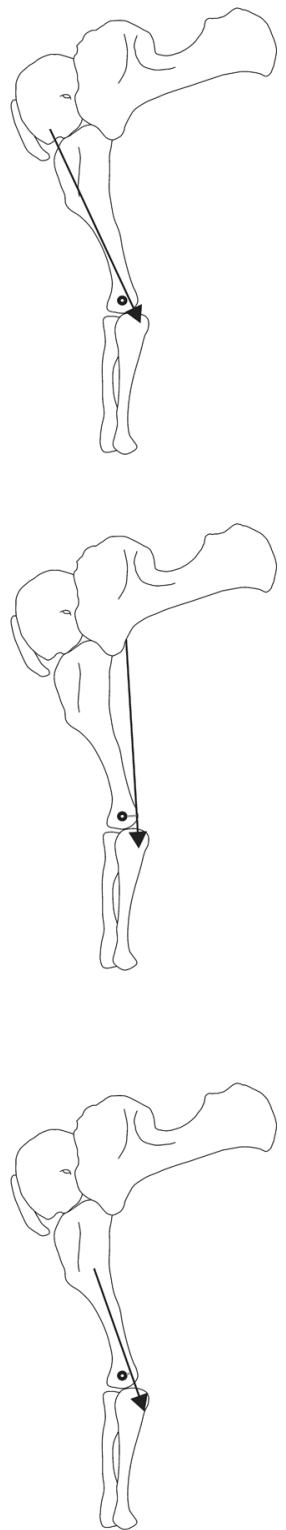

Figure 11. Lines of action and moment arms for the muscles triceps pars scapulocoracoidea (MTSC), triceps pars scapularis (MTS), and triceps pars humeralis (MTH) in 1, Saltasaurus; 2, Neuquensaurus; 3, Opisthocoelicaudia; 4, Diplodocus; 5, Apatosaurus; 6, Camarasaurus. 3, based on BorsukBialynicka (1977); 4-6, based on Wilhite (2003). Not to scale.

The sternal plates of titanosaur sauropods are crescentic and well-developed, with an elongation that is more than $70 \%$ of humerus length (Salgado et al., 1997; Wilson, 2002; D'Emic, 2012). Unlike non-titanosaur sauropods (e.g., Diplodocus, Apatosaurus, Camarasaurus; Wilhite, 2003) titanosaurian sternal plates would not have been oriented subvertically because such orientation would determine an extremely deep thoracic cage and, additionally, would prevent force transmission from the limbs to the trunk (Schwarz et al., 2007b; Hohn, 2011). The more plausible anatomical and biomechanical configuration for titanosaurs is with the sternal plates oriented in an oblique way, assuming the sternal plates were in contact with the medial margin of the coracoids (Schwarz et al., 2007b; Hohn, 2011; Otero, 2011). If we assume this configuration, the pectoralis muscle, which occupies most of the ventral/cra- 
nial surface of the sternal plates, increases the mediolateral component (adduction/abduction) of its line of action, which is reflected in larger moment arms for this component in the titanosaurs analyzed here (Fig. 10; Supplementary Online Information Tab. 1). Conversely, in non-titanosaur sauropods, the craniocaudal component (protraction/retraction) of $m$. pectoralis shows larger moment arms.

The presence of an enlarged olecranon is a feature present in Titanosauria and extremely developed in Saltasaurini. The $m$. triceps is the more important extensor muscle in tetrapods, the origin of which is located (depending on the group) in the scapula, coracoids, and humerus, and its insertion is on the olecranon process. The direct relationship between the development of the olecranon and the $m$. triceps is well known in mammals. A great development of this process involves an increase in the mechanical advantage of $m$. triceps for forearm extension (Vizcaíno and Milne, 2002).

Among the analyzed sauropods, the moment arms for the three portions of $m$. triceps display larger moment arms in saltasaurines than in Apatosaurus, Diplodocus and Camarasaurus, in a relationship of 2:1 (Fig. 11; Supplementary Online Information Tabs. 2-3). The main antagonists of $m$. triceps are the flexor $\mathrm{mm}$. biceps and humeroradialis. From the latter two, $m$. biceps display the larger moment arms for titanosaurs, being Neuquensaurus the taxon in which it has the larger moment arm. Conversely, m. humeroradialis shows similar values in all analyzed sauropods, except for Neuquensaurs which, again, displays the highest values. In sum, for the flexion-extension pair, titanosaur sauropods considered here have a higher mechanical advantage than non-titanosaur sauropods (Fig. 10; Supplementary Online Information Tabs. 4-5).

Summarizing, the titanosaurs analyzed here have a high mechanical advantage in the adductor-abductor and the extension-flexion pairs, and such mechanical advantage is not present in the 'narrow-gauged' sauropods studied here. Hence, this muscle pattern seems to be characteristic of 'wide-gauged' sauropods and could have counteracted the wider pose of the limbs.

Regarding the pelvic girdle and hindlimbs, if we take a look at the way in which the femur articulates to the acetabulum, it can be seen that in elephants the acetabulum faces ventrally, determining a ventral articulation of the femora with the pelvis. Thus, the weight of the elephant body is transmitted mostly vertically to the limbs, producing a compressional load regime as present in Greek columns (Fig. 9.1). In 'narrow-gauged' sauropods (e.g., Camarasaurus) the acetabulum does not face downwards, but laterally; hence, the femur articulates laterally with the pelvis, not ventrally as in elephants (Fig. 9.2, 9.4). Therefore, in sauropods the limbs do not act as strict columns, and show some lateromedial bending as well (Wilson and Carrano, 1999: fig. 2). This is why the traditional 'elephantine-like' posture does not fit entirely with the sauropod hindlimb pattern.

On the other hand, the titanosaur 'wide-gauged' stance exemplified by the ichnotaxa Sauropodichnus Calvo, 1991, and Titanopodus González Riga and Calvo, 2009, is determined by the proximal one-third of the femoral shaft canted inward relative to the rest of the shaft, and by the distal femoral condyles bevelled dorso-medialy (Wilson and Carrano, 1999) (Fig. 9.3). According to this pattern, we here propose an 'arch-like' hindlimb architecture for titanosaur hindlimbs. As in roman arches (e.g., bridges, windows) the loads would be distributed in a compressive way, but also would transmit horizontal loads outwards, laterally separating the limbs from each other (Fig. 9.4). This pattern is evident in the animal when both hindlimbs are supporting the weight (i.e., animal in standing position).

Despite the way in which the femur articulates to the acetabulum, limb elements of elephants and non-titanosaur sauropods are closely aligned relative to the ground reaction force, reducing bending moments, and thus, the risk of bone fractures (Biewener, 1989; Hutchinson and Gatesy, 2006; Preuschoft et al., 2011). But, what about titanosaurs? Are titanosaur hindlimbs prepared to support such bending moments produced by their posture? To answer these questions we have to look at the femoral geometry. Titanosaur femora exhibit an extremely eccentric shaft crosssection and were subject to higher lateromedial bending than in non-titanosaurs (Wilson and Carrano, 1999). As with an I-beam, an eccentric femoral cross section counteracts the lateromedial forces created by the weight of the animal due to the 'arch-like' geometry of the pelvis and hindlimbs, suggesting that titanosaur femora did not act like columns as in non-titanosaur sauropods or elephants.

The broad pelvic girdle of titanosaurs is the result of the 
(1)
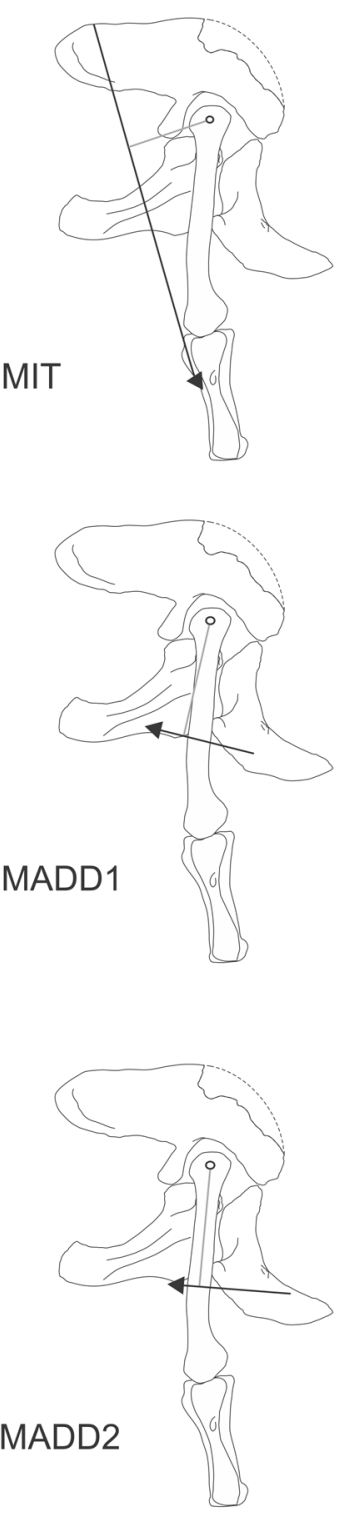

(2)
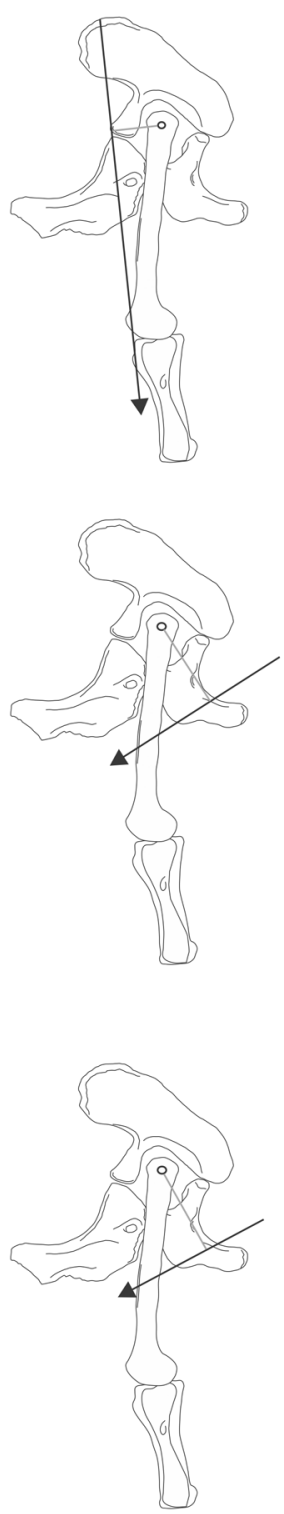

(3)
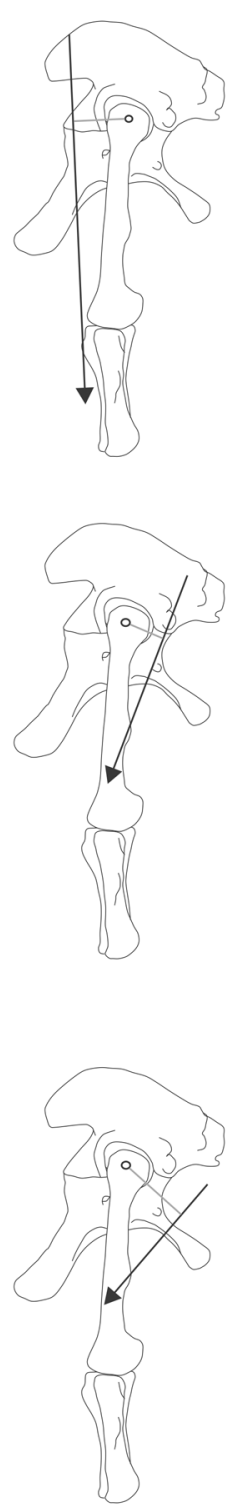

(4)
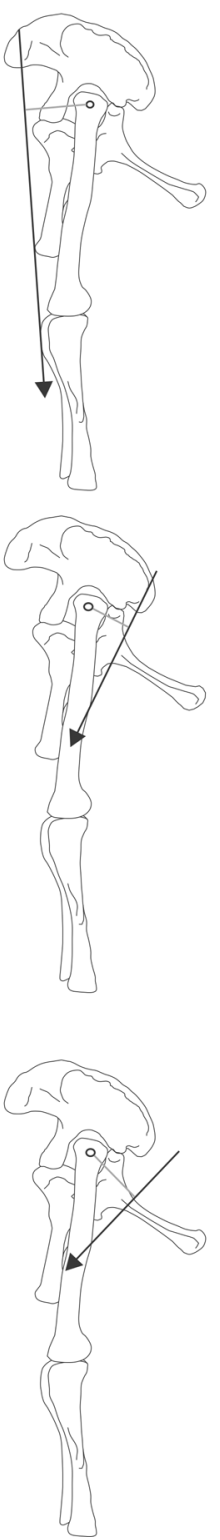

(5)
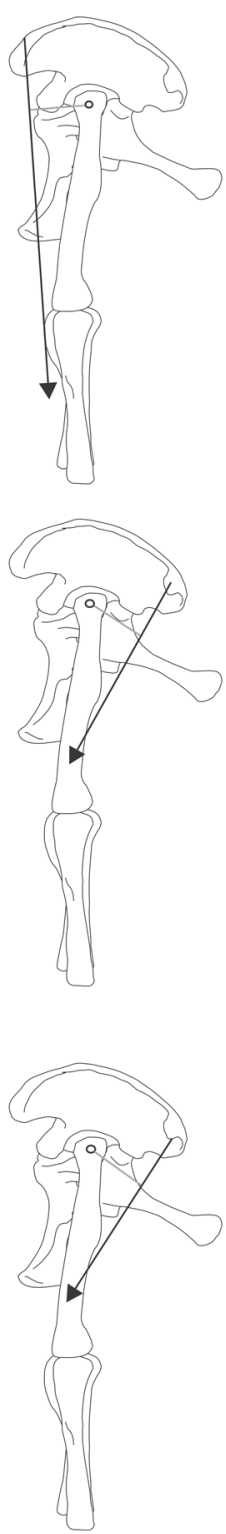

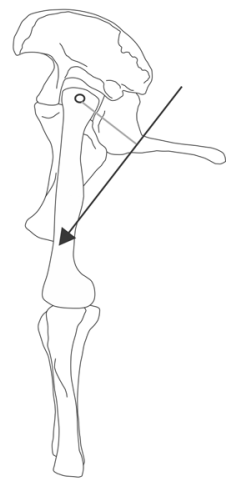

(6)
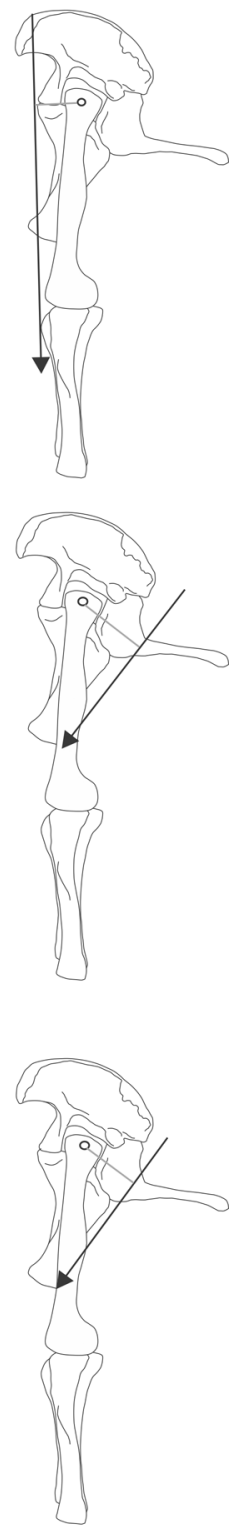

Figure 12. Lines of action and moment arms for the muscles iliotibialis cranialis (MIT), adductor femoris 1 (MADD1), and adductor femoris 2 (MADD2) in 1, Saltasaurus; 2, Rocasaurus; 3, Opisthocoelicaudia; 4, Diplodocus; 5, Apatosaurus; 6, Camarasaurus. 3, based on Borsuk-Bialynicka (1977); 4-6, based on Wilhite (2003). Not to scale.

nearly horizontal and laterally projected preacetabular lobes of the ilia. The anterior portion of the $m$. iliotibialis is involved in that skeletal configuration, shifting far and laterally its origin from the hip joint. This shifting of the cranial portion of $m$. iliotibialis would have produced moment arms larger in Rocasaurus and Saltasaurus than in 'narrow-gauged' sauropods, in which the preacetabular blades of the ilium are not oriented outwardly (Supplementary Online Informa- tion Tab. 6). Additionally, this would also have increased the antero-posterior component of the muscle's line of action, thereby improving the extension action (Wilson and Carrano, 1999; Otero, 2011).

The adductor musculature also displays changes in titanosaur sauropods. In a femur laterally angled outward from the acetabulum, produced by 'bevelled' distal condyles, the lines of action of the adductor musculature act in a 
(1) $\mathrm{F}$
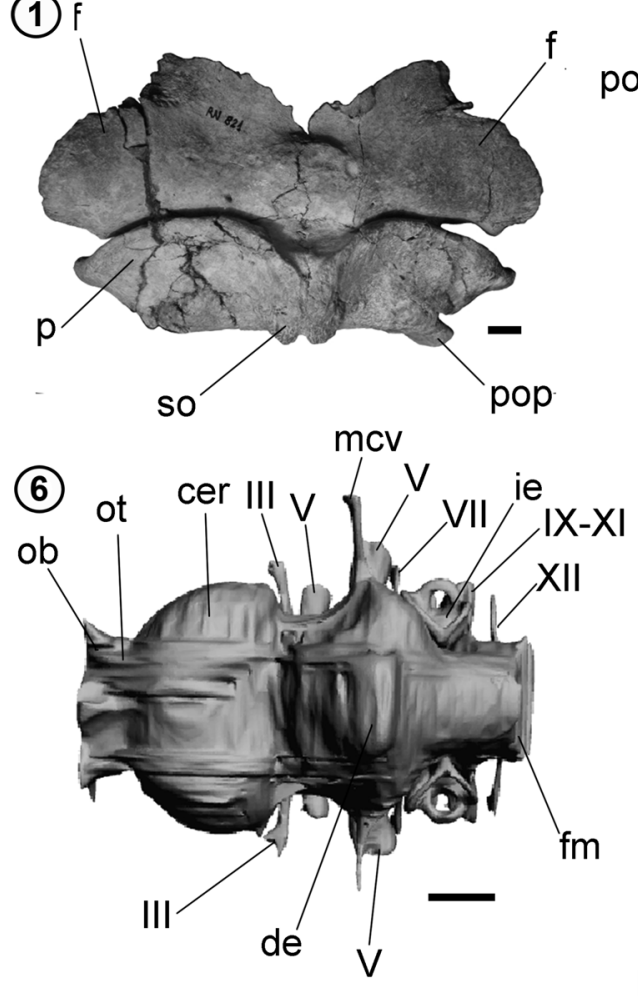

(7)

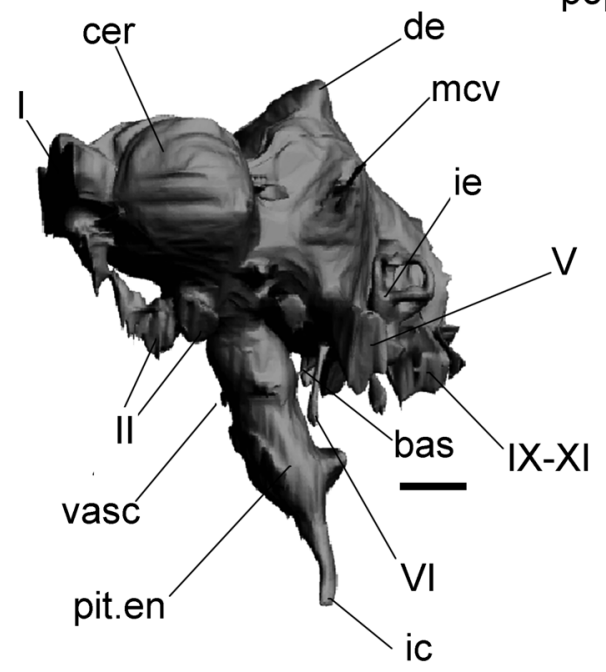

(2)

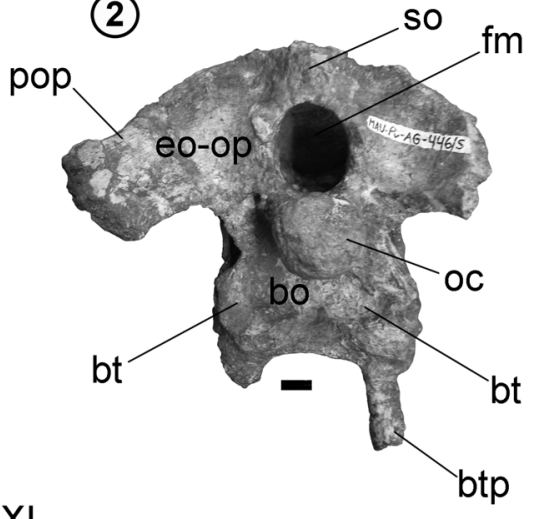

(4)

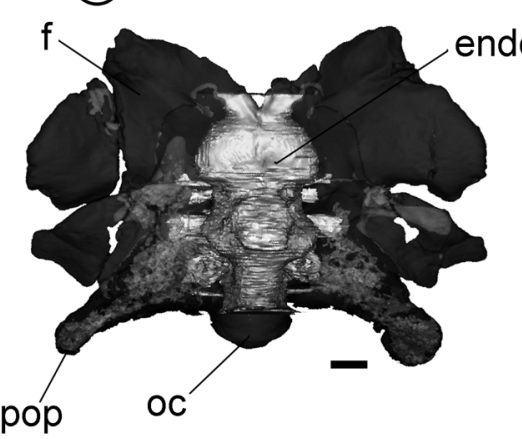

(8)

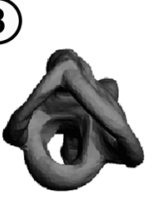

psc (9)
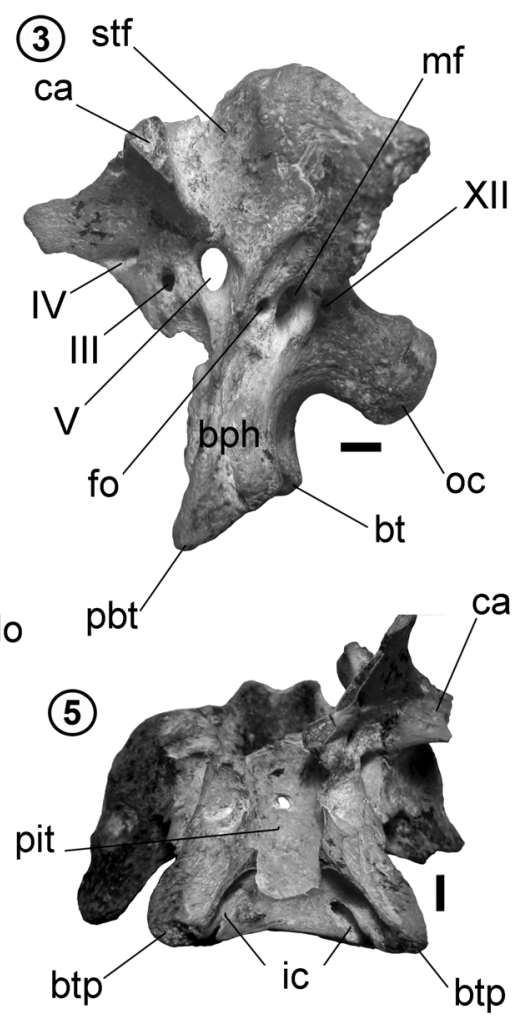

asc

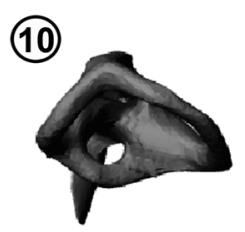

Isc
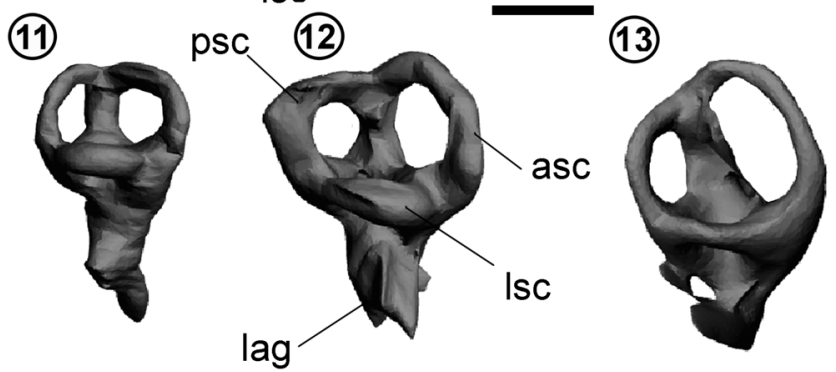

Figure 13. Titanosaurid braincase, brain and inner ear morphology. 1, Bonatitan (MACN-RN 821), skull roof in dorsal view; 2, Muyelensaurus Calvo, González Riga, and Porfiri, 2007 (MAV-PV-AG 446/1), braincase in posterior view; 3, 5, braincase of titanosaur indet. MML-Pv 194; 3, braincase in left lateral view; 5, braincase in anteroventral view (detail of internal carotid artery passage); 4, 6-7, digital reconstruction of braincase and cranial endocast of Bonatitan; 4, braincase in dorsal view, the bone is rendered semitransparent to see the endocranial cavity; 6-7, cranial endocasts in dorsal and left lateral views respectively; 8-13, comparison of titanosaurid and diplodocoid inner ear morphology; 8, 11, right inner ear of Bonatitan in 8, dorsal and 11, lateral, views; 9, 12, right inner ear of Antarctosaurus (MACN-RN 6904) in 9, dorsal and 12, lateral, views; 10, 13, right inner ear of the diplodocoid Amargasaurus Salgado and Bonaparte, 1991 in 10, dorsal and 13, lateral, views. Abbreviations: asc, anterior semicircular canal; bas, basilar artery; bo, basioccipital; bph, basisphenoid; bt, basal tuber; btp, basipterygoid process; ca, crista antotica; cer, cerebral hemisphere; de, dorsal expansion; endo, endocranial cavity; eo-op, exoccipital-opisthotic complex; f, frontal; fm, foramen magnum; fo, fenestra ovalis; ic, internal carotid artery passage; ie, inner ear; lag, lagena; Isc, lateral semicircular canal; mcv, medial cerebral vein; mf, metotic foramen; ob, olfactory bulb; oc, occipital condyle; ot, olfactory tract; p, parietal; pbt, basipterygoid process; pit, pituitary fossa; pit.en, pituitary cast; pop, paroccipital process; psc, posterior semicircular canal; so, supraoccipital; stf, suptratemporal fossa; vasc, vascular element; I-XII, cranial nerves. 12, 10, 13, modified from Paulina Carabajal et al. 2014. Scale bars $=1 \mathrm{~cm}$. 
different way than in 'narrow-gauged' sauropods, in which the femora are straight-shafted. In 'wide-gauged' trackmakers, the legs are not just beneath the body, but extend laterally outward from the hip joint; then, the line of action of the $\mathrm{mm}$. adductores femores have a principal mediolateral component, improving the adduction action, in contrast to that of 'narrow-gauged' sauropods. Besides, the osteological correlates for the origin site of the $\mathrm{mm}$. adductors femores (lateral surface of ischium; Meers, 2003) varies significantly among the analyzed sauropods, placing the origin site in a more distal position in the ischium of Saltasaurus and Rocasaurus, increasing the moment arm for the hip joint, particularly in the $m$. adductor femoris 2 (Fig. 12, Supplementary Online Information Tabs. 7-8). This larger moment arms in saltasaurine sauropods could have counteracted the wide hindlimb stance, in the same way that the $m$. pectoralis did in the scapular girdle and forelimbs stand position.

In summary, at least derived titanosaurs probably displayed a limb posture that moves away from the typical sauropod columnar pattern. The shoulder and pelvic girdle architecture of titanosaurs suggests a broader posture than that of non-titanosaur sauropods. Such postural change is reflected in the shifting of specific muscular attachments that counteract the wide posture of the limbs (as originally noted by Wilson and Carrano, 1999), a hypothesis quantitatively corroborated in this contribution.

\section{NEUROANATOMY AND SENSORIAL PHYSIOLOGY}

Interpretations about the sensorial capabilities of extinct animals were historically based on casts of the internal cranial spaces occupied by not preserved soft tissues (see Jerison, 1969; Hopson, 1979), such as the brain and inner ear. As the braincase, sauropod cranial endocasts are in general short and transversely wide, unlike the elongated and laterally compressed endocasts that characterizes prosauropods and theropods (e.g., Hopson, 1979, 1980; Sereno et al., 2007; Witmer et al., 2008; Knoll and SchwarzWings, 2009; Balanoff et al., 2010; Paulina Carabajal, 2012; Knoll et al., 2013) (Fig. 13).

Many titanosaur braincases -isolated or associated with other bones of the same skeleton- have been found in Argentinean Patagonia over the last years. These were described in some detail in Bonatitan Martinelli and Forasiepi, 2004, Narambuenatitan (Filippi et al., 2011), and several unnamed specimens (Calvo and González Riga, 2004; Calvo and Kellner, 2006; Paulina Carabajal and Salgado, 2007; García et al., 2008; Paulina Carabajal et al., 2008) (Fig. 13). Some of these studies include the cavities once filled by soft tissues, such as the endocranium (occupied in life by the brain and other associated organs and soft tissues) and the inner ear (Paulina Carabajal and Salgado, 2007; Paulina Carabajal et al., 2008; Paulina Carabajal, 2009b, 2012).

In the sauropod braincase, there are three characteristics that distinguish the endocranium from that of other saurischians: absence or extreme reduction of the floccular recess, high dorsum sellae formed by basisphenoid and laterosphenoid, and enlarged pituitary fossa. (1) The floccular recess, located on the anterior aspect of the vestibular eminence, hosts the floccular process of the cerebellum and is generally not present in sauropods. Recently, small floccular recesses have been reported in the endocranial casts of Nigersaurus Sereno et al., 1999 (Sereno et al., 2007), Giraffatitan Paul, 1988 ("Brachiosaurus" in Knoll and Schwarz-Wings, 2009) and a new rebbachisaurid from northern Patagonia (Paulina Carabajal et al., 2013). Galton and Knoll (2006) also reported a floccular recess in the endocranial cavity of a possible sauropod, although this material is very fragmentary and, thus, informatively ambiguous. In the unnamed titanosaurid MCF-PVPH 765 (Paulina Carabajal et al., 2008), there is a circular area crossed by numerous small foramina on the anterior wall of the vestibular eminence, evidencing the close relationship between this part of the cerebellum and the labyrinth of the inner ear, more specifically the anterior semicircular canal. In contrast, in theropods the floccular recess is always present. It is also present (although relatively less developed in terms of size) in prosauropods such as Adeopapposaurus sp. Martínez, 2009, Plateosaurus sp. Meyer, 1837 (Galton, 1984, 1985) and Massospondy/us sp. (Gow, 1990). The flocculus is a region of the cerebellum related to the coordination of head, eye and neck movements. In flying reptiles (e.g., Witmer et al., 2003) and in living birds (e.g., Witmer and Ridgely, 2009), the extremely enlarged floccular recess is associated with the vestibular system and the vestibulo-ocular reflex. In saurischians, the presence and relative development of the floccular recess seems to be related to the degree of bipedalism, since its absence is probably due to a reduced 
need for balance and orientation control in sauropods relative to the condition in theropods (Chatterjee and Zheng, 2002; Witmer et al., 2003). Therefore, the opposite condition (complete absence of floccular process) observed in titanosaurids is probably related to the cursorial adaptation (quadrupedalism) but also suggests a lower capacity of complex movements, including the neck and head. (2) The dorsum sellae is high and formed by the basisphenoid and the laterosphenoids. In sauropods, the floor of the endocranial cavity is basically horizontal, and ends anteriorly in a tall dorsum sellae dorsally projected into the endocranial cavity. This transversely oriented wall is formed mainly by the basisphenoid, and the laterosphenoids participate dorsally sending medial projections that contact its counterpart on the midline (Paulina Carabajal, 2009a). In contrast, in theropods the dorsum sellae is formed by the basisphenoid, and a medial contact between the prootics, which form a transversal bridge fused to the dorsum sellae (Tykoski, 1998), has been only reported for the coelophysoid Syntarsus kayentakatae Tykoski, 1998. A similar situation is observed in adult specimens of Massospondylus (Gow, 1990). Therefore, in sauropods the laterosphenoid contact on the mid-line seems to be a conservative character among dinosaurs. The neurological implications of a dorsally developed dorsum sellae in dinosaurs are not clear. In other extinct reptiles such as dicynodonts, the relative development of the dorsum sellae has been related to an enlargement of the hypophysis or pituitary gland (Surkov and Benton, 2004). This may be valid also for sauropods. Nevertheless, the functional significance of this enlargement is still obscure (see below). (3) The pituitary fossa is large, postero-ventrally elongated and tube-shaped (Fig. 13.5-7). In sauropods, the pituitary fossa is generally a tubular cavity, longer than wide, postero-ventrally excavated within the basisphenoid (e.g., Chatterjee and Zheng, 2002; Janensch, 1935-36; García et al., 2008; Knoll and Schwarz-Wings, 2009; Knoll et al., 2012; Paulina Carabajal, 2012). In theropods, on the other hand, the pituitary fossa is a bulbous cavity projected vertically from the floor of the endocranium and relatively smaller than that observed in sauropods (Paulina Carabajal, 2009a). The volume of the fossa relative to the volume of the endocranial cavity in the studied titanosaurs (e.g., Antarctosaurus, Bonatitan, Saltasaurus, and the titanosaurid MGPIFD-GR 118; Paulina Carabajal, 2012) varies between 5 and 7\%. In the studied titanosaurids (e.g., Antarctosaurus, Bonatitan, Saltasaurus, and the unnamed titanosaurids MPCA-Pv 80 and MGPIFD-GR 118), a constriction in the mid-section of the pituitary fossa subdivides it into two cavities, one anterodorsal (corresponding probably to the adenohypophysis) and the other posteroventral (corresponding probably to the neurohypophysis), the last directly related to the internal carotid veins (Paulina Carabajal, 2012). The striking enlargement of the pituitary fossa in sauropods suggests the enlargement of the pituitary gland. Some authors, however, stated that the pituitary gland has a positive allometric relationship with body size. Thus, the large pituitary fossa in sauropods just resulted from their body size (Edinger, 1942). Based on extensive work on extant mammals, birds, reptiles and amphibians it is clear that in these forms the anterior lobe of the pituitary gland is an essential factor in the control of the size and reproductive cycle (Matthews, 1939). Studies in humans (Tsunoda et al., 1997) and small mammals (Pankakoski and Tahka, 1982) stated that the size of the pituitary gland varies with age and sex, between younger and older subjects and between female and male subjects. The pituitary gland is greater in mature females than mature males, and sexual maturation is usually accompanied by adrenal growth. In humans, the size increases during adolescence due to normal physiological hypertrophy, but the most striking physiological changes are seen during pregnancy when the gland progressively enlarges reaching a maximal height immediately after birth. The enlarged pituitary fossa in sauropods may have been prepared to hold an enlarged gland during the reproductive season, suggesting a fast reproductive period or large production of eggs by each female (Paulina Carabajal, 2012). For example, each of the titanosaurid nests at the Auca Mahuevo site (Chiappe et al., 2004) has 15-34 eggs. However, extant reptiles such as crocodiles and turtles lay large numbers of eggs, but have relatively small pituitary glands compared with sauropods. On the other hand, if the gland maintained its size during life, the large size observed in sauropods could be related mainly to growth function, producing a fast period of growth in hatchlings that lead to reach the adult size in a few years, as proposed by several authors (see Griebeler and Werner, 2011 and references therein).

Other braincase characters in titanosaurs are the loca- 
tion of the foramen for the internal carotid arteries. They enter the basicranium trough foramina located ventromedial to the basipterygoid process (Fig. 13.5), and this is the reason why the foramina are not visible in a lateral view of the braincase (Paulina Carabajal, 2012). They penetrate the pituitary fossa trough separate foramina. Finally, most titanosaurids are characterized by a single foramen for the branches of cranial nerves IX-XI and XII respectively. Endocranially, the floor of the medullar fossa is basically flat and horizontal, and there is no medullar eminence.

\section{Titanosaur endocranium}

The endocranial cavity in titanosaurs is globose, low and transversely wide (Fig. 13.6). The olfactory tract is extremely short and horizontally projected in front of the cerebral hemispheres, unlike the long and antero-dorsally projected olfactory tract and bulbs in basal sauropods such as Shunosaurus Dong, Zhou, and Zhang, 1983 (Chatterjee and Zheng, 2002), Spinophorosaurus Remes et al., 2009 (Knoll et al., 2012), dicraeosaurids (Janensch, 1935-36) and other diplodocoids such as Apatosaurus (Balanoff et al., 2010) and the titanosauriform Giraffatitan (Knoll and Schwarz-Wings, 2009).

The sutures and the vascularization marks are not visible in the endocranial casts of Bonatitan (Paulina Carabajal, 2012) and the Titanosauria indet. specimen MGPIFD-GR 118 (Paulina Carabajal and Salgado, 2007). This indicates that the duramater was thick and therefore the brain did not completely occupy the cavity as has been proposed for other sauropods (Witmer et al., 2008; Knoll and SchwarzWings, 2009). However, there are differences between the morphology of these endocrania and those of other non-titanosaurian sauropods (e.g., Shunosaurus, Camarasaurus, Diplodocus) regarding the angle of the cephalic flexure, inclination of the pituitary fossa, and position and relative size of the cranial nerves II, III, IV, V and VII, which could represent characteristics of Titanosauria (Paulina Carabajal, 2012). Unlike Camarasaurus and Diplodocus, the endocrania of the Patagonian titanosaurs do not show the big vascular sinuses that form prominent furrows, recesses and openings on the endocranial surface (Witmer et al., 2008). In turn, in the studied titanosaurs, the short olfactory tract and bulbs are horizontal and aligned with the forebrain, in a similar way to what is observed in the diplodocoid Nigersaurus (Sereno et al., 2007). Contrarily, in Camarasaurus and Diplodocus the olfactory bulbs are relatively long and strongly inclined with respect to the longest axis of the forebrain. This is a result of the caudal retraction of the nasal cavity and the telescoping of the braincase (Sereno et al., 2007; Witmer et al., 2008). Nevertheless, olfaction seems to have been less important behaviourally in sauropods in general (Sereno et al., 2007). In the studied endocasts (Paulina Carabajal, 2012), the olfactory bulb cavities represent less than $2 \%$ of the endocranial cavity volume, meaning that olfaction was probably not a very well developed sense in titanosaurids.

\section{Inner ear}

The inner ear of sauropods is characterized by a simple and conical lagena, an anterior semicircular canal larger than the posterior semicircular canal, and a lateral semicircular canal smaller than the two other ones (Galton, 1985) (Fig. 13.8-13).

Titanosaurs in particular have short, robust and subequal in size semicircular canals in comparison with other sauropods (Paulina Carabajal, 2012). Because the development of the semicircular canals has been associated with behavioural patterns that require agility (relation between the labyrinth and the vestibulo-ocular reflex), the short and small semicircular canals of sauropods would be reflecting a decrease of the compensatory movements of eyes and head (Witmer et al., 2008). The evolutionary morphology pattern shows a clear reduction of the semicircular canals, principally the anterior semicircular canal, from the larger and slender anterior semicircular present in Jurassic basal forms and diplodocoids (e.g., Spinophorosaurus, Giraffati$\tan )$ to the short and robust semicircular canals in the Cretaceous titanosaur forms (Paulina Carabajal, 2012). This morphology, together with the assumption of short necks for this clade, strongly suggests that titanosaurids had less movement of the neck and head (at least lateral movements) when compared with other sauropods. There is evidence across many species showing that labyrinth dimensions are closely related to the dynamics of the natural movement repertoire unique to each species (Clarke, 2005). Recent studies relate both the simplicity of the inner ear and the loss of pneumaticity of the middle ear with poor discrimination of low-frequency sounds; as well as with move- 
ments of the neck, head, and eyes, which would have been rather slow. This in turn is consistent with the loss of the flocculus of the cerebellum in most sauropods (Witmer et al., 2008).

\section{DISCUSSION AND CONCLUSIONS}

The sample of remains that provide paleobiological information is yet reduced in comparison with the large number of titanosaur taxa formally described, and future discoveries and studies on titanosaurs should test the extent of the inferences presented here against titanosaurs as a whole or to subgroups within this diverse clade of herbivorous dinosaurs. The information presented above allows a rough characterization of some aspects of titanosaur paleobiology, based mainly on recent discoveries and studies from South American specimens. This characterization is summarized as follow:

Titanosaurs laid relatively small eggs $(10-25 \mathrm{~cm}$ diameter) and most records suggest that they laid a great number of eggs (up to 35) in excavated nests. It is not certain whether the eggs had been covered or not, nor if these eggs were hatched or not. Based on the low fracturing of the hatched eggs in the Indian oospecies, Mohabey (2005) suggested that these hatchlings left the nest immediately after hatching, a condition clearly precocial (see Griebeler and Werner, 2011). Chiappe et al. (2005) also inferred little or no parental care of their clutches based on adult size and proximity between clutches, suggesting that titanosaurs would have been precocial. Traditionally, the precocial strategy has been interpreted as primitive among Archosauria (Starck, 1993, 1994). The developmental stage of the embryos or neonates can be inferred from development of the epiphysis of the long bones, which has been used to infer the altricial vs. precocial condition of some dinosaurs (Horner and Weishampel, 1988; Chure et al., 1994; Horner and Currie, 1994). The osteohistological study of the Argentinean titanosaur embryos from Auca Mahuevo (ossification sequence, the relative development of the osseous tissue of the limb bones) and the presence of certain anatomical characters (e.g., 'egg-tooth'-structure) carried out by García (2008) provided data supporting the altriciality of these titanosaur embryos. Another case of alleged altriciality was recently inferred for an Early Jurassic sauropodomorph from China, probably belonging to Lufen- gosaurus Young, 1941 (see Reisz et al., 2013). In summary, although the evidence is ambiguous for titanosaurs, some evidence from the Auca Mahuevo embryos suggests a condition closest to altriciality or at least semialtriciality.

Evidence from accumulations of eggs from disparate localities around the globe indicates that adult titanosaur individuals likely shared large and probably monospecific nesting grounds (Sander et al., 2008; Grellet-Tinner and Fiorelli, 2010; Vilá et al., 2010b), although other records suggest that contiguous accumulations of eggs of different sauropod species may have partially overlapped (Salgado et al., 2009). In some cases, there is evidence that these reproductive areas were successively used throughout many nesting seasons. Although we do not know whether the titanosaur eggs were buried or not, their eggshell probably changed (water vapor conductance) during incubation, a topic that should be more thoroughly studied in the future.

While titanosaur skulls are rare, the limited available evidence suggests their skull morphology varied significantly during early ontogenetic stages (for instance, the snout lengthened markedly), which was surely accompanied by changes in the food procesing mechanics. These inferences are based on the exceptional findings of titanosaur embryos at Auca Mahuevo, in which the maxillary teeth reached a more posterior position than in the skulls of all taxa from which adult cranial remains are known (e.g., Nemegtosaurus, Tapuiasaurus, Rapetosaurus); in this regard, it is probable that the hatchlings used all the maxillary teeth for food cutting or processing. However, the type of teeth is basically similar in embryos/hatchlings from Auca Mahuevo and in those of the few known adult titanosaur skulls, which may be indicative of the same basic diet, a developmental constraint or both. In this regard, although it is possible that the hatchlings may have eaten softer vegetation, it is suggestive that their teeth were apparently relatively stronger, with a proportionally thicker enamel layer and smaller pulp cavities (García and Cerda, 2010a).

The hypothesis that the food procesing mechanics of the titanosaur embryos/hatchlings was somewhat different from that in adults is also inferable from the relatively short skull of the Auca Mahuevo embryos, their non-shortened infraorbital region, and (probably) the non-confinement of the teeth to the anterior snout. These features again contrast with the morphology of all known adult skulls of ti- 
tanosaurs. Similarly, juvenile Diplodocus has been thought to have had a different feeding behavior from that of adults, although in this case such an inference was based mostly on the fact that the juveniles of Diplodocus are roundsnouted instead square, as in the adults (Withlock et al., 2010).

As previously mentioned, several (but not all) titanosaur taxa have an extensive development of Haversian remodeling, even in not fully-grown individuals. The relative abundance of Haversian bone in such taxa could respond to several, non-mutually exclusive factors. For example, intensive bone remodeling could be linked to the extreme 'porosity' of the axial and appendicular skeleton. In titanosaurs, the precaudal vertebrae are somphospondylous (=camellate sensu Wedel et al., 2000); moreover, some taxa reveal internal cavities (probably pneumatic in origin) in the caudal vertebrae and/or in the ilia (Sanz et al., 1999; Powell, 2003; Salgado et al., 2005; Xu et al., 2006; Hocknull et al., 2009; Woodward and Lehman, 2009; Cerda et al., 2012). The presence of pneumatic cavities in the axial skeleton (and part of the appendicular skeleton) implies the resorption of a very important volume of bone tissue, and a substantial reduction on the capabilities of calcium storage. For this reason, the long bones were probably the main source for calcium and phosphate of the organism during life, probably reflected in the extreme cortical remodeling in the long bones.

Another possible explanation, recently proposed by Stein et al. (2013) for ankylosaurs, suggests that the high secondary reconstruction in long bones could be linked to the osteoderm formation in titanosaurs. In armoured titanosaurs, long bones could be employed as a mineral source for osteoderm formation, enhancing the degree of Haversian tissue in the cortical bone. The heavy secondary remodeling may have been originated during the early stages of the dermal armor development, first leading to early resorption activity in the long bones, then to osteoderm formation, and then to increased remodeling of the limb bones (Stein et al., 2013). The possible relationship between PSP, osteoderms and secondary bone in titanosaurs appears as a critical issue to thoroughly test in future studies.

At least derived titanosaurs probably displayed limb postures differing from the typical columnar or 'elephant- like' pattern inferred for other sauropods. Specifically, shoulder and pelvic girdle architecture of titanosaurs suggests a broader posture than that of non-titanosaur sauropods, which is related to a shift in the specific muscular attachments that would counteract the wide posture of the limbs.

Studies on the neuroanatomy of titanosaurs are also relevant for some paleobiological inferences. The presence of a floccular recess in the brain of some titanosaurs such as Nemegtosaurus could support the hypothesis that certain titanosaurs could occasionally adopt a bipedal posture, as proposed by Wilson and Carrano (1999). Titanosaur brain morphology shows a tendency to the reduction of the midbrain, and reduction of the olfactory tract and bulbs, meaning that olfaction was probably not a very well developed sense in titanosaurs. The inner ear is characterized by the reduction of the anterior semicircular canal and the robustness of the labyrinth in comparison with non-titanosaurian sauropods. This marked trend is evident in the evolution of titanosaurs when the plesiomorphic condition present in the Jurassic forms (basal sauropods and diplodocoids) is compared to the Cretaceous titanosaurs. Some of the latter would have been capable of capturing sounds in a relatively wide range of high frequencies, although not to the extent of living birds. Finally, in titanosaurs the rotation of the braincase based on the position of the lateral semicircular canal, the reduction of the anterior semicircular canal of the inner ear, the absence of floccular process, and the elevated position of the external nares would have restricted lateral rotation of the head with a minimal movement of the neck. Although titanosaurs have a braincase that is less rotated than that of diplodocoids, the situation would be the same. Detailed studies on neck morphology and mobility in titanosaurs, however, still need to be carried out to test this hypothesis.

We have presented here an updated review of recent advances and current knowledge of the paleobiology of titanosaurs, principally derived from the study of South American forms. Among the mentioned topics, titanosaurs evolved a series of paleobiologically interesting features, including a particular dental morphology and position of the toothrow, changes in neck length and locomotor posture, differences in their osteohistology, as well as changes in their neuroanatomy. The topics summarized and reviewed 
here represent advances on the paleobiology of titanosaurs. Yet, many other topics are required to fully understand titanosaurs as living biological entities, such as their relationship with different paleoenvironments. For this, paleobotanical and taphonomical data need to be integrated too. Other topics that look promising and potentially useful for understanding titanosaur paleobiology are the peculiar histology of this group and its relationship with the dynamics of calcium reservoirs, metabolism, and reproduction. Paleopathological studies are still underdeveloped for this group, but future studies on this topic will allow evaluating titanosaur biology in a context never before dealt with. Finally, another line of promising research is centered on some aspects of the dentition of this group, such as dental histology, dental replacement pattern, and studies on the chewing mechanism and feeding habits, all of which will provide data for answering open questions on titanosaur biology.

\section{ACKNOWLDEGMENTS}

We thank W. Evans (Natural History Museum of Los Angeles County) for linguistic editing. This work was financed by the PICT 0357 (FONCYT) and PIP 6455 (CONICET) (to L.S.). The Jurassic Foundation and PIP 091 (CONICET) (to R.G.) PICT 1181 FONCYT to (IAC), and the Secretaría de Cultura de La Rioja and the Consejo Federal de Ciencia y Tecnología PICT 2482 FONCyT (to AO) (COFECYT) (SCTIP N ${ }^{\circ} 1198 / 06$ - Proyecto LR02/06) (to L.F.). We thank the reviewers J. A. Wilson and $M$. Sander whose observations and comments greatly improved our paper.

\section{REFERENCES}

Alexander, R.McN. 1985. Mechanics of posture and gait of some large dinosaurs. Zoological Journal of the Linnean Society 83: 1-25.

Alexander, R.McN. 1989. Dynamics of dinosaurs and other extinct gigants. Columbia University Press, New York, 167 p.

Apesteguía, S. 2004a. Sauropod anatomy and nest-excavation behavior. Ameghiniana, Suplemento Resúmenes 41: 33R.

Apesteguía, S. 2004b. Bonitasaura salgadoigen. et sp. nov.: a beaked sauropod from the Late Cretaceous of Patagonia. Naturwissenschaften 91: 493-497.

Attridge, J., Crompton, A.W., and Jenkins Jr, F.A. 1985. The Southern African Liassic prosauropod Massospondylus discovered in North America. Journal of Vertebrate Paleontology 5: 128-132.

Bakker, R.T. 1971. Ecology of the Brontosaurus. Nature 229: 172174.

Bakker, R.T. 1978. Dinosaur feeding behavior and the origin of the flowering plants. Nature 274: 661-663.

Balanoff, A.M., Bever, G.S., and Ikejiri, T. 2010. The braincase of Apatosaurus (Dinosauria: Sauropoda) based on computed tomography of a new specimen with comments on variation and evolution in sauropod neuroanatomy. American Museum Novatites 3677: 1-24.

Benson, R.B., Butler, R.J., Carrano, M.T., and O'Connor, P.M. 2012. Air-filled postcranial bones in theropod dinosaurs: physiologi- cal implications and the 'reptile'-bird transition. Biological Reviews 87: 168-193.

Berman, D.S., and McIntosh, J.S. 1978. Skull and relationships of the Upper Jurassic sauropod Apatosaurus (Reptilia, Saurischia). Bulletin of the Carnegie Museum of Natural History 8: 1-35.

Biewener, A.A. 1989. Scaling body support in mammals: limb posture and muscle mechanics. Science 245: 45-48.

Bonaparte, J.F., and Coria, R.A. 1993. Un nuevo y gigantesco saurópodo titanosaurio de la Formación Río Limay (Albiano-Cenomaniano) de la Provincia del Neuquén, Argentina. Ameghiniana 30: 271-282.

Bonaparte, J.F., and Powell, J.E. 1980. A continental assemblage of tetrapods from the Upper Cretaceous of Northwestern Argentina (Sauropoda-Coelurosauria-Carnosauria-Aves). Mémories de la Société Géologique de France 139: 19-28.

Bonaparte, J.F., and Vince, M. 1979. El hallazgo del primer nido de Dinosaurios Triásicos (Saurischia, Prosauropoda), Triásico Superior de Patagonia, Argentina. Ameghiniana 16: 173-182.

Bonnan, M.F. 2003. The evolution of manus shape in sauropod dinosaurs: implications for functional morphology, forelimb orientation and phylogeny. Journal of Vertebrate Paleontology 23: 595-613.

Borsuk-Bialynicka, M. 1977. A new camarasaurid sauropod Opisthocoelicaudia skarzynskii, gen. n., sp. n. from the Upper Cretaceous of Mongolia. Palaeontologia Polonica 37: 1-64.

Britt, B.B. 1993. [Pneumatic postcranial bones in dinosaurs and other archosaurs. PhD Dissertation, University of Calgary, Alberta, 400 p. Unpublished.].

Brown, B. 1913. A new trachodont dinosaur, Hypacrosaurus, from the Edmonton Cretaceous of Alberta. Bulletin of the American Museum of Natural History 32: 395-406.

Butler, R.J., Barrett, P.M., and Gower, D.J. 2012. Reassessment of the evidence for postcranial skeletal pneumaticity in Triassic archosaurs, and the early evolution of the avian respiratory system. Plos ONE 7: e34094. doi:10.1371/journal.pone.0034094

Calvo, J.O. 1991. Huellas de dinosaurios en La Formación Río Limay (Albiano-Cenomaniano) Picún Leufú, Provincia de Neuquén, Argentina. (Ornithischia-Saurischia: Sauropoda-Teropoda). Ameghiniana 28: 241-258.

Calvo, J.O. 1994. Jaw mechanics in sauropod dinosaurs. Gaia 10: 183-193.

Calvo, J.O., and Bonaparte, J.F. 1991. Andesaurus delgadoin. g. n. sp. (Saurischia, Sauropoda) a titanosaurid dinosaur from the Río Limay Formation (Albian-Cenomanian), Neuquén, Argentina. Ameghiniana 28: 303-310.

Calvo, J.O., and González Riga, B.J. 2004. A new titanosaur braincase from Neuquén Province, northern Patagonia, Argentina. Ameghiniana, Suplemento Resúmenes 41: 38R.

Calvo, J.O., and Kellner, A.W. 2006. Description of a sauropod dinosaur braincase (Titanosauridae) from the Late Cretaceous Rio Colorado Subgroup, Patagonia. Anais da Academia Brasileira de Ciências 78: 175-182.

Calvo, J.O., Engelland, S., Heredia, S.E., and Salgado, L. 1997. First record of dinosaur eggshells (?Sauropoda-Megaloolithidae) from Neuquén, Patagonia, Argentina. Gaia 14: 23-32.

Calvo, J.O., González Riga, B.J., and Porfiri, J.D. 2007. A new titanosaur sauropod from the Late Cretaceous of Neuquén, Patagonia, Argentina. Arquivos do Museu Nacional 65: 485-504.

Campos, D.A., and Kellner, A.W.A. 1999. On some sauropod (Titanosauridae) pelves from the continental Cretaceous of Brazil. In: Y. Tomida, T.H. Rich, and P. Vickes-Rich (Eds.), Procceding of the Gandwanan Dinosaur Symposium. National Sciences Museum Monographs, Tokyo, p. 143-166. 
Campos, D.A., Kellner, A.W.A., Bertini, R.J., and Santucci, R.M. 2005. On a Titanosauridae (Dinosauria, Sauropoda) vertebral column from the Bauru Group, Late Cretaceous of Brazil. Arquivos do Museu Nacional 63: 565-593.

Carpenter, K. 1999. Eggs, Nest and Baby Dinosaurs. Indiana University Press, Bloomington and Indianapolis, $336 \mathrm{p}$.

Carrano, M.T. 2005. The evolution of sauropod locomotion: morphological diversity of a secondarily quadrupedal radiation. In: K.A. Curry Rogers, and J.A. Wilson (Eds.), The Sauropods: Evolution and Paleobiology. University of California Press, Berkeley, p. 229-249.

Casadío, S., Manera, T., Parras, A., and Montalvo, C.I. 2002. Huevos de dinosaurios (Faveoloolithidae) del Cretácico Superior de la cuenca del Colorado, provincia de La Pampa, Argentina. Ameghiniana 39: 285-293.

Cerda, I.A., and Powell, J.E. 2009. Patrón de crecimiento de Saltasaurus loricatus Bonaparte y Powell 1981 (Sauropoda: Titanosauria) inferido a partir de su histología ósea. Ameghiniana, Suplemento Resúmenes 46: 68R.

Cerda, I.A., and Powell, J.E. 2010. Dermal armor histology of Saltasaurus loricatus, an Upper Cretaceous sauropod dinosaur from Northwest Argentina. Acta Palaeontologica Polonica 55: 389-398.

Cerda, I.A., and Salgado, L. 2011. Bone microstructure of the Upper Cretaceous titanosaur sauropod Neuquensaurus australis Lydekker, 1893. Ameghiniana, Suplemento Resúmenes 48: 98R-99R.

Cerda, I.A., Salgado, L., and Powell, J.E. 2012. Extreme postcranial pneumaticity in sauropod dinosaurs from South America. Paläontologische Zeitschrift 86: 441-449.

Cerda, I.A., García, R.A., Powell, J.E., and López, O. In press. Morphology, microanatomy and histology of titanosaur (Dinosauria, Sauropoda) osteoderms from the Upper Cretaceous of Patagonia. Journal of Vertebrate Paleontology.

Cerda, I., Paulina Carabajal, A., Salgado, L., Coria, R.A., Reguero, M.A, Tambussi, C.P., and Moly, J.J. 2011. The first record of a sauropod dinosaur from Antarctica. Naturwissenschaften 99: 83-87.

Chatterjee, S., and Zheng, Z. 2002. Cranial anatomy of Shunosaurus, a basal sauropod dinosaur the Jurassic of China. Zoological Journal of the Linnean Society 136: 145-169.

Chiappe, L.M., Salgado, L., and Coria, R.A. 2001. Embryonic skulls of titanosaur sauropod dinosaur. Science 293: 2444-2446.

Chiappe, L.M., Jackson, F., Coria, R.A., and Dingus, L. 2005. Nesting titanosaurs from Auca Mahuevo and adjacent sites. In: K.A. Curry Rogers, and J.A. Wilson (Eds.), The Sauropods: Evolution and Paleobiology. University California Press, Berkeley, p. 285302.

Chiappe, L.M., Coria, R.A., Dingus, L., Jackson, F., Chinsamy, A., and Fox, M. 1998. Sauropod dinosaur embryos from the Late Cretaceous of Patagonia. Nature 396: 258-261.

Chiappe, L.M., Schmitt, J.G., Jackson, F.D., Garrido, A.C., Dingus, L., and Grellet-Tinner, G. 2004. Nest structure for sauropods: sedimentary criteria for recognition of dinosaur nesting trace. Palaios 19: 89-95.

Chinsamy-Turan, A. 2005. The Microstructure of dinosaur bone: Deciphering biology with fine-scale techniques. Johns Hopkins University Press, Baltimore, $195 \mathrm{p}$.

Chure, D., Turner, C., and Peterson, F. 1994. An embryo of Camptosaurus from the Morrison Formation (Jurassic, middle Tithonian) in Dinosaur National Monument, Utah. In: K. Carpenter, K.F. Hirsch, and J.R. Horner (Eds.), Dinosaur Eggs and Babies. Cambridge University Press, New York, p. 298-311.

Clarke, A.H. 2005. On the vestibular labyrinth of Brachiosaurus brancai. Journal of Vestibular Research 15: 65-71.
Company, J. 2011. Bone histology of the titanosaur Lirainosaurus astibiae (Dinosauria: Sauropoda) from the Latest Cretaceous of Spain. Naturwissenschaften 98: 67-78.

Coombs, W.P. 1989. Modern analogs for dinosaur nesting and parental behavior. Geological Society of America, Special Paper 238: 51-53.

Cope, E.D. 1877. On a gigantic saurian from the Dakota Epoch of Colorado. Paleontological Bulletin 25: 5-10.

Coria, R.A., and Chiappe, L.M. 2001. Tooth remplacement in a sauropod premaxilla from the Upper Cretaceous of Patagonia Argentina. Ameghiniana 38: 463-466.

Coria, R.A., and Salgado, L. 1999. Nuevos aportes a la anatomía craneana de los saurópodos titanosaurios. Ameghiniana, Suplemento Resúmenes 36: 98R.

Currey, J.D. 2003. The many adaptations of the bones. Journal of Biomechanics 36: 1487-1495.

Curry, K.A. 1999. Ontogenetic histology of Apatosaurus (Dinosauria: Sauropoda): new insights on growth rates and longevity. Journal of Vertebrate Paleontology 19: 654-665.

Curry Rogers, K.A. 2005. Titanosauria. In: K.A. Curry Rogers, and J.A. Wilson (Eds.), The Sauropods: Evolution and Paleobiology. University of California Press, Berkeley, p. 50-103.

Curry Rogers, K.A., and Forster, C.A. 2001. The last of the dinosaur titans: a new sauropod from Madagascar. Nature 412: 530-543.

Curry Rogers, K.A., and Forster, C.A. 2004. The skull of Rapetosaurus krausei (Sauropoda: Titanosauria) from the Late Cretaceous of Madagascar. Journal of Vertebrate Paleontology 24: 121-144.

Curry Rogers, K., D'Emic, M.D., Vickaryous, M., and Cagan, A. 2011. Sauropod dinosaur osteoderms from the Late Cretaceous of Madagascar. Nature Communications 2: 564. doi: 10.1038/ ncomms1578.

de Valais, S., Apesteguía, S., and Udrizar Sauthier, D. 2003. Nuevas evidencias de dinosaurios de la Formación Puesto Yeruá (Cretácico), Provincia de Entre Ríos, Argentina. Ameghiniana 40: 631-635.

Deeming, D.C. 2002. Importance and evolution of incubation in avian reproduction. In: D.C. Deeming (Ed.), Avian incubation: behaviour, environment and evolution. Oxford University Press, Oxford, p. 1-7.

Deeming, D.C. 2006. Ultrastructural and functional morphology of eggshells supports the idea that dinosaur eggs were incubated buried in a substrate. Palaeontology 49: 171-185.

D'Emic, M.D. 2012. The early evolution of titanosauriform sauropod dinosaurs. Zoological Journal of the Linnean Society 166: 624-671.

D'Emic, M.D., and Wilson, J.A. 2012. Bone histology of a dwarf sauropod dinosaur from the latest Cretaceous of Jordan and a possible biomechanical explanation for "titanosaur-type" bone histology. Journal of Vertebrate Paleontology 32: 83.

D'Emic, M.D., Whitlock, J.A., Smith, K.M., Fisher, D.C., and Wilson, J.A. 2013. Evolution of high tooth replacement rate in sauropod dinosaur. PIOS ONE 8: e69235. DOI: 10.1371/journal.pone. 0069235

Díez Días, V., Pereda-Suberbiola, X., and Sanz, J.L. 2012. Juvenil and adult teeth titanosaurian dinosaur Liranosaurus (Sauropoda) from the Late Cretaceous of Iberia. Geobios 45: 265-274.

Dong, Z., Zhou, S., and Zhang, Y. 1983. The dinosaurian remains from Sicuani basin, China. Palaeontologia Sinica 23: 1-145.

Edinger, T. 1942. The Pituitary Body in Giant Animals Fossil and Living: A Survey and a Suggestion. The Quarterly Review of Biology 17: 31-45.

Edmund, A.G. 1960. Tooth replacement phenomena in the lower vertebrates. Contributions Life Science Division. Royal Ontario 
Museum 52: 1-190.

Enlow, D.H. 1962. Function of the Haversian system. American Journal of Anatomy 110: 269-305.

Faccio, G. 1994. Dinosaurian eggs from the Upper Cretaceous of Uruguay. In: K. Carpenter, J. Horner, and K.F. Hirsch (Eds.), Dinosaur Eggs and Babies. Cambridge University Press, New York, p. 7-55.

Farlow, J.O. 1992. Sauropod tracks and trackmakers: integrating the ichnological and skeletal records. Zubia 10: 89-138.

Ferguson, M.W.J. 1985. Reproductive biology and embryology of the crocodilians. In: C. Gans, F. Billett, and P.F.A. Maderson (Eds.), Biology of the Reptilia, Vol. 14 Development A. John Wiley and Sons, New York, p. 329-491.

Fernández, M.S. 2013. Análisis de cáscaras de huevos de dinosaurios de la Formación Allen, Cretácico Superior de Río Negro (Campaniano-Maastrichtiano): utilidad de los macro caracteres de interés parataxonómico. Ameghiniana 50: 79-97.

Fernández, M.S., and Khosla, A. 2015. Parataxonomic review of the Upper Cretaceous dinosaur eggshells belonging to the oofamily Megaloolithidae from India and Argentina. Historical Biology 27: 158-180.

Fernández, M.S., Simoncini, M.S., and Dyke, G. 2013. Irregularly calcified eggs and eggshells of Caiman latirostris (Alligatoridae: Crocodylia). Naturwissenschaften 100: 451-457.

Filippi, L.S., García, R.A., and Garrido, A. 2011. A new titanosaur sauropod dinosaur from Upper Cretaceous of North Patagonia, Argentina. Acta Palaeontologica Polonica 56: 505-520.

Fiorelli, L.E., Grellet-Tinner, G., Alasino, P.H., and Argañaraz, E. 2012. The geology and paleoecology of the newly discovered Cretaceous neosauropod hydrothermal nesting site in Sanagasta (Los Llanos Formation), La Rioja, northwest Argentina. Cretaceous Research 35: 94-117.

Fiorelli, L.E., Grellet-Tinner, G., Argañaraz, E., and Salgado, L. 2013. Tafonomía del sitio de nidificación de neosaurópodos de Sanagasta (La Rioja, Argentina): ejemplo de preservación excepcional en un paleoambiente hidrotermal del Cretácico. Ameghiniana 50: 389-406.

Fiorillo, A.R. 1991. Dental microwear on the teeth of Camarasaurus and Diplodocus: implications for sauropod paleoecology. In: Z. Kielan-Jaworowska, N. Heintz, and H.A. Nakrem (Eds.), Extended Abstracts of the Fifth Symposium on Mesozoic Terrestrial Ecosystems and Biota. Contributions from the Palaeontological Museum, University of Oslo, Norway, 364, p. 23-24.

Fiorillo, A.R. 1997. Tooth Wear. In: P.J. Currie, and K. Padian (Eds.), Encyclopedia of Dinosaurs. Academic Press, San Diego, California/London, p. 743-745.

Fiorillo, A.R. 1998. Dental microwear patterns of the sauropod dinosaurs Camarasaurus and Diplodocus: evidence for resource partitioning in the Late Jurassic of North America. Historical Biology 13: 1-16.

Fiorillo, A.R. 2008. Lack of variability in feeding patterns of the sauropod dinosaur Diplodocus and Camarasaurus (Late Cretaceous, Western USA) with respect to climate as indicated by tooth wear features. In: J.T. Sankey, and S. Baszio (Eds.), Vertebrate Microfossil Assemblages, their role in Paleoecology and Paleobiogeography. Indiana University Press, Bloomington, p. 104-116.

Fowler, D.W., and Hall, L.E. 2011. Scratch-digging sauropods, revisited. Historical Biology 23: 27-40.

Gallina, P.A. 2012. Histología ósea del titanosaurio Bonitasaura salgadoi (Dinosauria: Sauropoda) del Cretácico Superior de Patagonia. Ameghiniana 49: 289-302.

Gallina, P.A., and Apesteguía, S. 2011. Cranial anatomy and phylo- genetic position of the titanosaurian sauropod Bonitasaura salgadoi. Acta Palaeontologica Polonica 56: 45-60.

Galton, P.M. 1984. Cranial anatomy of the prosauropod dinosaur Plateosaurus from the Knollenmergel (Middle Keuper, Upper Triassic) of Germany. I. Two complete skull from Trossingen/ Württemberg with comments on the diet. Geologica et Palaeontologica 18: 139-171.

Galton, P.M. 1985. Cranial anatomy of the prosauropod dinosaur Plateosaurus from the Knollenmergel (Middle Keuper, Upper Triassic) of Germany. II. All the cranial material and details of soft-part anatomy. Geologica et Palaeontologica 19: 119-159.

Galton, P.M., and Knoll, F. 2006. A saurischian dinosaur braincase from the Middle Jurassic (Bathonian) near Oxford, England: from the theropod Megalosaurus or the sauropod Cetiosaurus?. Geological Magazine 143: 905-921.

García, R.A. 2007a. An 'egg-tooth'-like structure in titanosaurian sauropod embryos. Journal of Vertebrate Paleontology 27: 247252.

García, R.A. 2007b. Consideraciones sobre la fenestra preantorbital en embriones de dinosaurios saurópodos del Cretácico de Patagonia. Ameghiniana 44: 467-471.

García, R.A. 2008. [Estudio sobre Embriones de Dinosaurios Titanosaurios de Patagonia: Aspectos Filogenéticos y Evolutivos Implicados. Tesis Doctoral, Universidad Nacional del Comahue, Bariloche, 329 p. Unpublished.].

García, R.A. 2013. A giant tooth from the Late Cretaceous of Patagonia, Argentina: an enormous titanosaur or a large toothed titanosaur? Cretaceous Research 41: 82-85.

García, R.A., and Cerda, I.A. 2010a. Dentition and histology in titanosaurian dinosaur embryos. Palaeontology 53: 335-346.

García, R.A., and Cerda, I.A. 2010b. Dentición de los titanosaurios del Cretácico Superior de la provincia de Río Negro, Argentina: aspectos morfológicos, reemplazo e inserción. Ameghiniana 47: 45-60.

García, R.A., and Salgado, L. 2013. Titanosaur diversity at Salitral Moreno locality (Río Negro, Argentina) (Allen Formation, late Campanian-early Maastrichtian). Acta Palaeontologica Polonica 58: 269-284.

García, R.A., Paulina Carabajal, A., and Salgado, L. 2008. Un nuevo basicráneo de titanosaurio de la Formación Allen (CampanianoMaastrichtiano), Provincia de Río Negro, Patagonia, Argentina. Geobios 41: 625-633.

García, R.A., Salgado, L., Coria, R.A., and Chiappe, L.M. 2010. Osteología embrionaria de saurópodos titanosaurios de Neuquén (Argentina): aspectos ontogenéticos y evolutivos. Ameghiniana 47: 409-430.

Garrido, A.C. 2010. Paleoenvironment of the Auca Mahuevo and Los Barreales sauropod nesting-site (Late Cretaceous, Neuquén Province, Argentina). Ameghiniana 47: 99-106.

Gilmore, C.W. 1922. A new sauropod dinosaur from the Ojo Alamo Formation of New Mexico. Smithsonian Miscellaneous Collections 72: 1-9.

González Riga, B.J. 2003. A new titanosaur (Dinosauria Sauropoda) from the Upper Cretaceous of Mendoza, Argentina. Ameghiniana 40: 155-172.

González Riga, B.J., and Calvo, J.0. 2009. A new wide gauge Sauropod track site from the Late Cretaceous of Mendoza, Neuquén Basin, Argentina. Palaeontology 52: 631-640.

González Riga, B.J., and Curry Rogers, K.A. 2006. Osteohistology of the titanosaur Mendozasaurus (Dinosauria, Sauropoda): preliminary interpretations. $9^{\circ}$ Congreso Argentino de Paleontología y Bioestratigrafía (Córdoba), Resúmenes: 84.

Gow, C.E. 1990. Morphology and growth of the Massospondylus 
braincase (Dinosauria, Prosauropoda). Palaeontologia Africana 27: 59-75.

Grellet-Tinner, G., and Fiorelli, L.E. 2010. A new Argentinean nesting site showing neosauropod dinosaur reproduction in a Cretaceous hydrothermal environment. Nature Communications 1: 32. doi: 10.1038/ ncomms1031.

Grellet-Tinner, G., Fiorelli, L.E., and Salvador, R.B. 2012. Water vapor conductance of the Lower Cretaceous dinosaurian eggs from Sanagasta, La Rioja, Argentina - paleobiological and paleoecological implications for South American faveoloolithid and megaloolithid eggs. Palaios 27: 35-47.

Grellet-Tinner, G., Chiappe, L.M., Norell, M., and Bottjer, D. 2006. Dinosaur eggs and nesting behaviors: A paleobiological investigation. Palaeogeography, Palaeoclimatology, Palaeoecology 232: 294-321.

Griebeler, E.M., and Werner, J. 2011. The life cycle of sauropod dinosaurs. In: N. Klein, K. Remes, C.T. Gee, and P.M. Sander (Eds.), Biology of the sauropod dinosaurs. Indiana University Press, Bloomington, p. 261-273.

Grigorescu, D. 2010. The 'Tustea Puzzle': hadrosaurid (Dinosauria, Ornithopoda) hatchlings associated with Megaloolithidae eggs in the Maastrichtian of the Hateg Basin (Romania). Ameghiniana 47: 89-97.

Grigorescu, D., Weishampel, D., Norman, D., Seclaman, M., Rusu, M., Baltres, A., and Teodorescu, V. 1994. Late Maastrichtian dinosaur eggs from the Hateg Basin (Romania). In: K. Carpenter, K.F. Hirsch, and J.R. Horner (Eds.), Dinosaur Eggs and Babies. Cambridge University Press, New York, p. 75-87.

Hamburger, V., and Hamilton, H.L. 1951. A series of normal stages in the development of the chick embryo. Journal Morphology 88 : 49-98.

Hatcher, J.B. 1901. Diplodocus Marsh, its osteology, taxonomy and probable habits, with a restoration of the skeleton. Memoirs of the Carnegie Museum 1: 1-64.

Haughton, S.H. 1928. On some remains from the Dinosaur Beds of Nyasaland. Transactions of the Royal Society of South Africa 16: 67-75.

Hocknull, S.A., White, M.A., Tischler, T.R., Cook, A.G., Calleja, N.D., Sloan, T., and Elliott, E.A. 2009. New Mid-Cretaceous (Late Albian) dinosaurs from Winton, Queensland, Australia. PLOS ONE, 4: e6190. doi: 10.1371/journal.pone.0006190.

Hohn, B. 2011. Walking with the shoulder of giants: biomechanical conditions in the tetrapod shoulder girdle as a basis for sauropod shoulder reconstruction. In: N. Klein, K. Remes, C.T. Gee, and P.M. Sander (Eds.), Biology of the sauropod dinosaurs: understanding the life of giants. Indiana University Press, Bloomington and Indianapolis, p. 180-194.

Hopson, J.A. 1979. Paleoneurology. In: C. Gans, R.G. Northcutt, and P. Ulinski (Eds.), Biology of the Reptilia, Vol. 9. Academic Press, London, New York, San Francisco, p. 39-146.

Hopson, J.A. 1980. Relative brain size in dinosaurs - implications for dinosaurian endothermy. American Association for the Advancement of Science Symposium 28: 287-310.

Horner, J.R., and Currie, F.J. 1994. Embryonic and neonatal morphology and ontogeny of a new species of Hypacrosaurus (Ornitischia, Lambeosauridae) from Montana and Alberta. In: K. Carpenter, K.F. Hirsch, and J.R. Horner (Eds.), Dinosaur Eggs and Babies. Cambridge University Press, New York, p. 312-336.

Horner, J.R., and Weishampel, D.B. 1988. A comparative embryological study of two ornithischian dinosaurs. Nature 332: 256-257.

Horner, J.R., Padian, K., and de Ricqlès, A. 2001. Comparative ostehistology of some embryonic and perinatal archosaurs: de- velopmental and behavioral implications for dinosaurs. Paleobiology 27: 39-58.

Huene, F. von. 1929. Los saurisquios y ornitisquios del Cretáceo Argentino. Anales del Museo de La Plata 3: 1-196.

Huene, F. von. 1932. Die fossile Reptil-Ordnung Saurischia, ihre Entwicklung und Geschichte. Monographien Geologie Palaeontologie 4: 1-361.

Hutchinson, J.R., and Gatesy, S.M. 2006. Beyond the bones. Nature 440: 292-294.

Jackson, F.D., Varricchio, D., Jackson, R.A., Vilá, B., and Chiappe, L.M. 2008. Comparison of water vapor conductance in a titanosaur egg from the Upper Cretaceous of Argentina and a Megaloolithus siruguei egg from Spain. Palaeobiology 34: 226-246.

Jacobs, L.L., Winkler, D.A., Downs, W.R., and Gomani, E.M. 1993. New material of an Early Cretaceous titanosaurid sauropod dinosaur from Malawi. Palaeontology 36: 523-534.

Jain, S.L., and Bandyopadhyay, S. 1997. New titanosaurid (Dinosauria, Sauropoda) from the Late Cretaceous of Central India. Journal of Vertebrate Paleontology 17: 114-136.

Janensch, W. 1914. Übersicht über die Wirbeltierfauna der Tendaguru-Schichten, nebst einer kurzen Charakterisierung der neu aufgeführten Arten von Sauropoden. Archiv für Biontologie 3: 81-110.

Janensch, W. 1935-36. Die schädel der sauropoden Brachiosaurus, Barosaurus und Dicraeosaurus aus den Tendaguru-Schichten Deutsch-Ostrafrikas. Palaeontographica 1: 147-298.

Janensch, W. 1947. Pneumatizitat bei Wirbeln von Sauropoden und anderen Saurischien. Palaeontographica 3: 1-25.

Jerison, H.J. 1969. Brain evolution and dinosaur brains. The American Naturalist 103: 575-588.

Jianu, C.M., and Weishampel, D.B. 1999. The smallest of the largest, a new look at possible dwarfing in sauropod dinosaurs. Geologie en Mijnbouw 78: 335-343.

Johnson, R.E., and Ostrom, J.H. 1995. The forelimb of Torosaurus and an analysis of the posture and gait of ceratopsians. In: J. Thomasson (Ed.), Functional Morphology in Vertebrate Paleontology. Cambridge University Press, New York, p. 205-218.

Kellner, A.W. 1996. Remarks on Brazilian dinosaurs. In: F.E. Novas, and R.E. Molnar (Eds.), Proceedings of the Gondwanan Dinosaur Symposium. Memoirs of the Queensland Museum 29, p. 489532.

Kellner, A.W.A., and Azevedo, S.A.K. 1999. A new sauropod dinosaur (Titanosauria) from the Late Cretaceous of Brazil. In: Y. Tomida, T.H. Rich, and P. Vickes-Rich (Eds.), Procceding of the Gondwanan Dinosaur Symposium. National Sciences Museum Monographs, Tokyo, p. 111-142.

Kellner, A.W.A., Rubilar-Rogers, D., Vargas, A., and Suarez, M. 2011. A new titanosaur sauropod from the Atacama Desert, Chile. Anais da Academia Brasileira de Ciências 81: 211-219.

Kérourio, P. 1981. Nouvelles observations sur le mode de nidification et de ponte chez les dinosauriens du Crétacé terminal du Midi de la Frande. Compte Rendu Sommaire des Séances de la Societé Géologique de France 1: 380-414.

Klein, N., and Sander, P.M. 2008. Ontogenetic stages in the long bone histology of sauropod dinosaurs. Paleobiology 34: 247-263.

Klein, N., Sander, P.M., and Suteethorn, V. 2009. Bone histology and its implications for the life history and growth of the Early Cretaceous titanosaur Phuwiangosaurus sirindhornae. Geological Society, London, Special Publications 315: 217-228.

Klein, N., Sander, P.M., Stein, K., Le Loeuff, J., Carballido, J.L., and Buffetaut, E. 2012. Modified laminar bone in Ampelosaurus atacis and other titanosaurs (Sauropoda): Implications for life history and physiology. PLoS ONE: e36907. doi: 10.1371/jour- 
nal.pone.0036907.

Knoll, F., and Schwarz-Wings, D. 2009. Paleoneuroanatomy of Brachiosaurus. Annales of Paleontologie 95: 165-175.

Knoll, F., Ridgely, R.C., Ortega, F., Sanz, J.L., and Witmer, L.M. 2013. Neurocranial osteology and neuroanatomy of a Late Cretaceous titanosaurian sauropod from Spain (Ampelosaurus sp.). PLOS ONE 8: e54991. doi: 10.1371/journal.pone.0054991.

Knoll, F., Witmer, L.M., Ortega, F., Ridgely, R.C., and Schwarz-Wings, D. 2012. The braincase of the basal sauropod dinosaur Spinophorosaurus and 3D reconstructions of the cranial endocast and inner ear. PLOS ONE 7: e30060. doi: 10.1371/journal.pone.0030060.

Kohring, R. 1989. Fossile Eierschalen aus dem Garumnium (Maastrichtium) von Bastus (Provinz Lerida, NE-Spanien). Berliner Geowiss Abhandlungen (A) 1006: 267-275.

Kolbe, J.J., and Janzen, F.J. 2002. Impact of nest-site selection on nest success and nest temperature in natural and disturbed habitats. Ecology 83: 269-281.

Kues, B.S., Lehman, T., and Rigby, K.Jr. 1980. The teeth of Alamosaurus sanjuanensis a Late Cretaceous sauropod. Journal of Paleontology 54: 864-869.

Lapparent, A.F. 1958. Découverte d`un gisement d’oeufs de dinosauriens dans le Crétacé Supérieur du bassin de Tremp (Province de Lérida, Espagne). Comptes Rendus de l'Académie des Sciences de Paris 247: 1879-1880.

Lauder, G.V. 1995. On the inference of function from structure. In: J.J. Thomason (Ed.), Functional Morphology in Vertebrate Paleontology. Cambridge University Press, New York, p. 1-18.

Le Loeuff, J. 1995. Ampelosaurus atacis (nov. gen., nov. sp.) un nouveau Titanosauridae (Dinosauria, Sauropoda) du Crétacé supérieur de la haute Vallée de I'Aude (France). Comptes Rendus de I'Académie des Sciences de Paris 321: 693-696.

Lydekker, R. 1893. Contributions to the study of the fossil vertebrates of Argentina. I. The dinosaurs of Patagonia. Anales del Museo de La Plata (Sección Paleontología) 2: 1-14.

Machado, E.B., Avila, L.S., Nava, W.R., Campos, D.S., and Kellner, A.W.A. 2013. A new titanosaur sauropod from the Late Cretaceous of Brazil. Zootaxa 3701: 301-321.

Madsen, J.R., McIntosh, J.S., and Berman, S.D. 1995. Skull and atlasaxis complex of the Upper Jurassic sauropod Camarasaurus Cope (Reptilia: Saurischia). Bulletin of the Carnegie Museum of Natural History 30: 1-115.

Manera de Bianco, T. 1996. Nueva localidad con nidos y huevos de dinosaurios (Titanosauridae) del Cretácico Superior, Cerro Blanco, Yaminué, Río Negro, Argentina. Publicación Especial de la Asociación Paleontológica Argentina 4: 59-67.

Marsh, O.C. 1877a. Notice of some new dinosaurian reptiles from the Jurassic Formation. American Journal of Science (Serie 3) 14 : 514-516.

Marsh, O.C. 1877b. Characters of the Odontornithes, with notice of a new allied genus. American Journal of Science (Serie 3) 14 : 85-87.

Marsh, O.C. 1878. Principal characters of American Jurassic dinosaurs. Part I. American Journal of Science (Serie 3) 16: 411-416.

Marsh, O.C. 1889. Notice of new American dinosaur. American Journal of Science (Serie 3) 37: 331-336.

Martin, V., Buffetaut, E., and Suteethorn, V. 1994. A new sauropod from the Sao Khua Formation (Late Jurassic or Early Cretaceous) of northeastern Thailand. Comptes Rendus de I'Académie des Sciences de Paris 319: 1085-1092.

Martinelli, A.G., and Forasiepi, A.M. 2004. Late Cretaceous vertebrates from Bajo de Santa Rosa (Allen Formation), Río Negro Province, Argentina, with the description of a new sauropod dinosaur (Titanosauridae). Revista del Museo Argentino de Ciencias Naturales "Bernardino Rivadavia" 6: 257-305.

Martínez, R.N. 2009. Adeopaposaurus mognai gen. et sp. nov. (Dinosauria: Sauropodomorpha) with comments on adaptations of basal Sauropodomorpha. Journal of Vertebrate Paleontology 29: $142-164$.

Matthews, S.A. 1939. The relationship between the pituitary gland and the gonads in fundulus. The Biological Bulletin 76: 241-250.

McIntosh, J.S. 1990. Sauropoda. In: D.B.Weishampel, P. Dodson, and H. Osmólska (Eds.), The Dinosauria. University of California Press, Berkeley, p. 345-401.

Meers, M.B. 2003. Crocodylian forelimb musculature and its relevance to Archosauria. The Anatomical Record 274: 892-916.

Meyer, H. von. 1837. Mitteilung an Prof. Bronn (Plateosaurus engelhardti). Neües Jahrbuch Mineralogie Geologie und Paläontologie: 314-316.

Mikhailov, K.E. 1991. Classification of fossil eggshells of amniotic vertebrates. Acta Palaeontologica Polonica 36: 193-238.

Mikhailov, K.E., Bray, E.S., and Hirsch, K.F. 1996. Parataxonomy of fossil egg remains (Veterovata): principles and applications. Journal of Vertebrate Paleontology 16: 763-769.

Mohabey, D.M. 1984. Pathologic dinosaurian egg shells from Kheda district, Gujarat. Current Science 53: 701-703.

Mohabey, D.M. 2005. Late Cretaceous (Maastrichtian) nests, eggs, and dung mass (coprolites) of sauropods (titanosaurs) from India. In: K. Carpenter, and V. Tidwell (Eds.), Thunder-Lizards: The Sauropodomorph Dinosaurs. Indiana University Press, Bloomington, p. 466-490.

Mones, A. 1980. Nuevos elementos de la paleoherpetofauna del Uruguay (Crocodilia y Dinosauria). $2^{\circ}$ Congreso Argentino de Paleontología y Bioestratigrafía y $1^{\circ}$ Congreso Latinoamericano de Paleontología (Buenos Aires), Actas 1: 265-277.

Moratalla, J.J., and Powell, J.E. 1994. Dinosaur nesting patterns. In: K. Carpenter, K.F. Hirsch, and J.R. Horner (Eds.), Dinosaur Eggs and Babies. Cambridge University Press, New York, p. 37-46.

Mueller-Töwe, I.J., Sander, P.M., Schüller, H., and Thies, D. 2002. Hatching and infilling of dinosaur eggs as revealed by computed tomography. Palaeontographica 267: 119-168.

Nopcsa, F. 1915. Die Dinosaurier der siebenbürgischen Landesteile Ungarns. Mitteilungen aus dem Jahrbuche der Königlich ungarsichen geologischen Reichsanstalt 23: 1-26.

Novas, F.E., Salgado, L., Calvo, J.O., and Agnolín, F. 2005. Giant titanosaur (Dinosauria, Sauropoda) from the Late Cretaceous of Patagonia. Revista Museo Argentino Ciencias Naturales "Bernardino Rivadavia" 7: 37-41.

Nowinski, A. 1971. Nemegtosaurus mongoliensis n. gen., n. sp. (Sauropoda) from the Uppermost Cretaceous of Mongolia. Paleontologica Polonica 25: 57-81.

O'Connor, P.M. 2006. Postcranial pneumaticity: an evaluation of soft-tissue influences on the postcranial skeleton and the reconstruction of pulmonary anatomy in archosaurs. Journal of Morphology 267: 1199-1226.

O'Connor, P.M., and Claessens, L.P.A. 2005. Basic avian pulmonary design and flow-through ventilation in nonavian theropod dinosaurs. Nature 436: 253-256.

Osborn, J.W. 1977. The interpretation of patterns in dentitions. Biological Journal of the Linnean Society 9: 217-229.

Otero, A. 2011. [Saurópodos Saltasaurinae del territorio argentino: reconstrucción de la musculatura y función del esqueleto apendicular. Tesis Doctoral, Facultad de Ciencias Naturales y Museo, Universidad Nacional de La Plata, La Plata, 388 p. Unpublished.].

Otero, A., and Vizcaíno, S.F. 2008. Hindlimb musculature and function of Neuquensaurus australis Lydekker (Sauropoda: Ti- 
tanosauria). Ameghiniana 45: 333-348.

Owen, R. 1854. Descriptive Catalogue of the fossil organic remains of reptilian and pisces contained in the Museum of the Royal College of Surgeons of England. Taylor and Francis, London, 184 p.

Pankakoski, E., and Tahka, K.M. 1982. Relation of adrenal weight to sex, maturity and season in five species of small mammals. Annales Zoologici Fennici 19: 225-232.

Paul, G.S. 1988. The brachiosaur giants of the Morrison and Tendaguru with a description of a new subgenus, Giraffatitan, and a comparison of the world's largest dinosaurs. Hunteria 2: $1-14$.

Paul, G.S., and Christiansen, P. 2000. Forelimb posture in neoceratopsian dinosaurs: implications for gait and locomotion. Paleobiology 26: 450-465.

Paulina Carabajal, A. 2009a. [El neurocráneo de los dinosaurios Theropoda de la Argentina. Osteología y sus implicancias filogenéticas. Tesis Doctoral, Facultad de Ciencias Naturales y Museo, Universidad Nacional de La Plata, La Plata, 540 p. Unpublished.].

Paulina Carabajal, A. 2009b. Anatomía endocraneana del saurópodo Bonatitan reigi Martinelli y Forasiepi (Titanosauridae) del Cretácico Superior de Norpatagonia. Ameghiniana, Suplemento Resúmenes 46: 89R.

Paulina Carabajal, A. 2012. Neuroanatomy of titanosaurid dinosaurs from the Upper Cretaceous of Patagonia, with comments on endocranial variability within Sauropoda. The Anatomical Record 295: 2141-2156.

Paulina Carabajal, A., and Salgado, L. 2007. El basicráneo de un titanosaurio (Dinosauria, Sauropoda) del Cretácico Superior del norte de Patagonia: descripción y aportes al conocimiento del oído interno de los dinosaurios. Ameghiniana 44: 109-120.

Paulina Carabajal, A., Carballido, J., and Currie, P. 2014. Braincase, neuroanatomy and neck posture of Amargasaurus cazaui (Sauropoda: Dicraeosauridae) and its implications for understanding head posture in sauropods. Journal of Vertebrate $\mathrm{Pa}$ leontology 34 (4): 870-882.

Paulina Carabajal, A., Coria, R.A., and Chiappe, L.M. 2008. An incomplete Late Cretaceous braincase (Sauropoda: Titanosauria): New insights about the dinosaurian inner ear and endocranium. Cretaceous Research 29: 643-648.

Paulina Carabajal, A., Haluza, A., and Canale, J.I. 2013. New rebbachisaurid (Sauropoda, Diplodocoidea) skull remains from Candeleros Formation (Cenomanian), Neuquén Province, Argentina. Ameghiniana, Suplemento Resúmenes 50: 27R.

Perry, S.F., Breuer, T., and Pajor, N. 2011. Structure and function of the sauropod respiratory system. In: N. Klein, K. Remes, C.T. Gee, and P.M. Sander (Eds.), Biology of the Sauropod Dinosaurs: Understanding the Life of Giants. Indiana University Press, Bloomington and Indianapolis, p. 83-93.

Pol, D., and Powell, J.E. 2007. Skull anatomy of Mussaurus patagonicus (Dinosauria: Sauropodomorpha) from the Late Triassic of Patagonia. Historical Biology 19: 125-144.

Powell, J.E. 1979. Sobre una asociación de dinosaurios y otras evidencias de vertebrados del Cretácico Superior de la región de La Candelaria, Provincia de Salta, Argentina. Ameghiniana 16: 191-204.

Powell, J.E. 1985. Hallazgo de nidadas de huevos de dinosaurios (Sauropoda Titanosauridae) del Cretácico Superior del Salitral Ojo de Agua, Provincia de Río Negro. $2^{a s}$ Jornadas Argentina de Paleontología de Vertebrados (San Miguel de Tucumán), Resúmenes: 15.

Powell, J.E. 1986. [Revisión de los Titanosáuridos de América del Sur. Tesis Doctoral, Universidad Nacional de Tucumán, San Miguel de Tucumán, 493 p. Unpublished.].
Powell, J.E. 1987a. Morfología del esqueleto axial de los dinosaurios titanosáuridos (Saurischia, Sauropoda) del Estado de Minas Gerais. Anais do $10^{\circ}$ Congresso Brasileiro de Paleontogía (Rio de Janeiro), Anais: 155-171.

Powell, J.E. 1987b. The late Cretaceous fauna of Los Alamitos, Patagonia, Argentina, Parte VI-The titanosaurids. Revista del Museo Argentino de Ciencias Naturales "Bernardino Rivadavia" 3 : 147-153.

Powell, J.E. 1992. Hallazgo de huevos asignables a dinosaurios Titanosauridae (Saurischia, Sauropoda) de la Provincia de Río Negro, Argentina. Acta Zoologica Lilloana 41: 381-394.

Powell, J.E. 2003. Revision of South American titanosaurid dinosaurs: palaeobiological, palaeobiogeographical and phylogenetic aspects. Records of the Queen Victoria Museum 111: $1-173$.

Preuschoft, H., Hohn, B., Stoinski, S., and Witzel, U. 2011. Why so huge? Biomechanical reasons for the acquisition of large size in sauropod and theropod dinosaurs. In: N. Klein, K. Remes, C.T. Gee, and P.M. Sander (Eds.), Biology of the Sauropod Dinosaurs: understanding the life of giants. Indiana University Press, Bloomington and Indianapolis, p. 195-216.

Rauhut, O.W., and Fechner, R. 2005. Early development of the facial region in a non-avian theropod dinosaur. Procceding of the Royal Society B 272: 1179-1183.

Reisz, R.R., Evans, D.C., Sues, H., and Scott, D. 2010. Embryonic skeletal anatomy of the sauropodomorph dinosaur Massospondylus from the Lower Jurassic of South Africa. Journal of Vertebrate Paleontology 30: 1653-1665.

Reisz, R.R., Scott, D., Sues, H., Evans, D.C., and Raath, M.A. 2005. Embryos of an Early Jurassic prosauropod dinosaur and their evolutionary significance. Science 309: 761-764.

Reisz, R.R., Huang, T.D., Roberts, E.M., Peng, S.R., Sullivan, C., Stein, K, Le Blanc, A.R.H., Shieh, D.Bi., Chang, R.S., Chiang, C.C., Yang, C., and Zhong, S. 2013. Embryology of Early Jurassic dinosaur from China with evidence of preserved organic remains. Nature 496: 210-214.

Remes, K., Ortega, F., Fierro, I., Joger, U., Kosma, R., and Ferrer, J.M.M. 2009. A new basal sauropod dinosaur from the Middle Jurassic of Niger and the early evolution of sauropoda. PLOS ONE 4: e6924. doi: 10.1371/journal.pone.0006924.

Ricqlès, A. de, Mateus, O., Antunes, M.T., and Taquet, T. 2001. Histomorphogenesis of embryos of Upper Jurassic from Lourinha (Portugal). Comptes Rendus de l'Académie des Sciences de Paris, Sciences de la Terre et des Planètes 332: 647-656.

Rigg, E.S. 1903. Brachiosaurus altithorax, the largest known dinosaur. American Journal of Science 15: 299-306.

Rimblot-Baly, F., de Ricqlès, A., and Zylberberg, L. 1995. Analyse paléohistologique d'une série de croissance partielle chez Lapparentosaurus madagascariensis (Jurassique moyen): essay sur la dynanique de croissance d'un dinosaure sauropode. Annales de Paléontologie 81: 49-86.

Romano, M., Whyte, M.A., and Jackson, S.J. 2007. Trackway Ratio: A new look at trackway gauge in the analysis of quadrupedal dinosaur trackway and its implications for ichnotaxonomy. Ichnos 14: 257-270.

Sabath, K. 1991. Upper Cretaceous amniote eggs from the Goby Desert. Acta Palaeontologica Polonica 36: 151-192.

Salgado, L. 1999. The Macroevolution of Diplodocimorpha: a developmental model. Ameghiniana 36: 203-216.

Salgado, L. 2000. [Evolución y Paleobiología de los Saurópodos Titanosauridae. Tesis Doctoral, Facultad de Ciencias Naturales y Museo, Universidad Nacional de La Plata, La Plata, 300 p. Unpublished.]. 
Salgado, L. 2003. Considerations on the bony plates assigned to titanosaurs (Dinosauria, Sauropoda). Ameghiniana 40: 441-456.

Salgado, L., and Azpilicueta, C. 2000. Un nuevo saltasaurino (Sauropoda, Titanosauridae) de la provincia de Río Negro (Formación Allen, Cretácico Superior), Patagonia, Argentina. Ameghiniana 37: 259-264.

Salgado, L., and Bonaparte, J.F. 1991. Un nuevo saurópodo Dicraeosauridae Amargasaurus cazaui gen. et sp. nov. de la Formación La Amarga, Neocomiano de la provincia del Neuquén, Argentina. Ameghiniana 28: 333-346.

Salgado, L., and Bonaparte, J.F. 2007. Sauropodomorpha. In: Z. Gasparini, L. Salgado, and R.A. Coria (Eds.), Patagonian Mesozoic Reptiles. Indiana University Press, Bloomington, p. 188-228.

Salgado, L., and Calvo, J.O. 1997. Evolution of titanosaurid sauropods. II The cranial evidence. Ameghiniana 34: 33-48.

Salgado, L., and Carvalho, I.S. 2008. Uberabatitan riberoi, a new titanosaur from the Marília Formation (Bauru Group, Upper Cretaceous), Minas Gerais, Brazil. Palaeontology 51: 881-901.

Salgado, L., Coria, R.A., and Calvo, J.O. 1997. Evolution of titanosaurid sauropods. I: phylogenetic analysis based on the postcranial evidence. Ameghiniana 34: 3-32.

Salgado, L., Coria, R.A., and Chiappe, L.M. 2005. Osteology of the sauropod embryos from the Upper Cretacoeus of Patagonia. Acta Palaeontologica Polonica 50: 79-92.

Salgado, L., Magalhaes Ribeiro, C.M., García, R.A., and Fernández, M. 2009. Late Cretaceous Megaloolithid eggs from Salitral de Santa Rosa (Río Negro, Patagonia, Argentina): inferences on the titanosaurian reproductive biology. Ameghiniana 44: 605-620.

Salgado, L., Coria, R.A., Maghalaes Ribeiro, C.M., Garrido, A., Rogers, R., Simón, M.E., Arcucci, A.B., Curry Rogers, K., Paulina Carabajal, A., Apesteguía, S., Fernández, M., García, R.A., and Talevi, M. 2007. Upper Cretaceous dinosaur nesting sites of the Río Negro Province (Salitral Ojo de Agua and Salinas de Trapalcó-Salitral de Santa Rosa) Northern Patagonia, Argentina. Cretaceous Research 28: 392-404.

Sander, P.M. 2000. Longbone histology of the Tendaguru sauropods: implications for growth and biology. Paleobiology 26: $466-488$.

Sander, P.M., Klein, N., Stein, K., and Wings, O. 2011. Sauropod bone histology and implications for sauropod biology. In: N. Klein, K. Remes, C.T. Gee, and P.M. Sander (Eds.), Biology of the Sauropod Dinosaurs: Understanding the life of giants. Indiana University Press, Bloomington, p. 276-302.

Sander, P.M., Mateus, O., Laven, T., and Knötschke, N. 2006. Bone histology indicates insular dwarfism in a new Late Jurassic sauropod dinosaur. Nature 441: 739-741.

Sander, P.M., Peitz, C., Jackson, F.D., and Chiappe, L.M. 2008. Upper Cretaceous titanosaur nesting sites and their implications for sauropod dinosaur reproductive biology. Palaeontographica 284: 69-107.

Sander, P.M., Klein, N., Buffetaut, E., Cuny, G., Suteethorn, V., and Loeuff, J.L. 2004. Adaptative radiation in sauropod dinosaurs: bone histology indicates rapid body size acceleration. Organism, Diversity \& Evolution 4: 165-173.

Sander, P.M., Christian, A., Clauss, M., Fechner, R., Gee, C.T., Griebeler, E.M., Gunja, H.C., Hummel, J., Mallison, H., Perry, S.F., Preuschoft, H., Rauhut, O.W.M., Remes, K., Tütken, T., Wings, O., and Witzel, U. 2010. Biological of the sauropod dinosaurs: The evolution of gigantism. Biological Reviews. doi: 10.1111/j.1469185x.2010.00137.x.

Santucci, R.M., and Bertini, R.J. 2006. A new titanosaur from western Sao Paulo State Upper Cretaceous Bauru Group, south-east Brazil. Palaeontology 49: 59-66.
Sanz, J.L., Powell, J.E., Le Loeuff, J., Martínez, R., and Pereda-Suberbiola, X. 1999. Sauropod remains from the Upper Cretaceous of Laño (northcentral Spain). Titanosaur phylogenetic relationships. Estudios del Museo de Ciencias Naturales de Álava 14: 235-255.

Scheyer, T.M., and Sander, P.M. 2004. Histology of ankylosaur osteoderms: implications for systematics and function. Journal of Vertebrate Paleontology 20: 874-893.

Schubert, B.W., and Ungar, P.S. 2005. Wear facet and enamel spalling in tyrannosaurid dinosaur. Acta Palaeontologica Polonica 50: 93-99.

Schwarz, D., Frey, E.D., and Meyer, C.A. 2007a. Pneumaticity and softtissue reconstructions in the neck of diplodocid and dicraeosaurid sauropods. Acta Palaeontologica Polonica 52: 167-188.

Schwarz, D., Frey, E., and Meyer, C.A. 2007b. Novel Reconstruction of the orientation of the pectoral girdle in Sauropods. The Anatomical Record 290: 32-47.

Sciutto, J.C., and Martínez, R.D. 1994. Un nuevo yacimiento fosilífero de la Formación Bajo Barreal (Cretácico Tardío) y su fauna de saurópodos. Naturalia Patagónica, Ciencias de la Tierra 2: 27-47.

Sereno, P.C., Wilson, J.A., Witmer, L.M., Whitlock, J.A., Maga, A., Ide, O., and Rowe, T.A. 2007. Structural extremes in a Cretaceous dinosaur. PLOS ONE 2: e1230. doi: 10.1371/journal.pone. 0001230.

Sereno, P.C., Beck, A.L., Dutheil, D.B., Larsson, H.C.E., Lyon, G.H., Moussa, B., Sadleir, R.W., Sidor, C.A., Varricchio, D.J., Wilson, G.P., and Wilson, J.A. 1999. Cretaceous Sauropods from the Sahara and the Uneven Rate of Skeletal Evolution Among Dinosaurs. Science 286: 1342-1347.

Seymour, R.S. 1979. Dinosaur eggs: gas conductance through the shell, water loss during incubation and clutch size. Paleobiology 5: 1-11.

Shine, R., and Harlow, P.S. 1996. Maternal manipulation of offspring phenotypes via nest-site selection in an oviparous lizard. Ecology 77: 1808-1817.

Simón, M.E. 2006. Cáscaras de huevos de dinosaurios de la Formación Allen (Campaniano-Maastrichtiano), en Salitral Moreno, Provincia de Río Negro, Argentina. Ameghiniana 43: 513-528.

Simoncini, M.E., Fernández, M.S., and lungman, J. 2014. Cambios estructurales en cáscaras de huevos de Caiman latirostris. Revista Mexicana de Biodiversidad 85: 78-83.

Starck, J.M. 1993. Evolution of avian ontogenies. In: D.M. Power (Ed.), Current Ornithology. Plenum Press, New York, p. 257-366.

Starck, J.M. 1994. Quantitative desing of the skeleton in bird hatchling: does tissue compartmentalization limit posthatching growth rates? Journal of Morphology 222: 113-131.

Stein, M., Hayashi, S., and Sander, P.M. 2013. Long bone histology and growth patterns in ankylosaurs: Implications for life history and evolution. PLOS ONE 8: e68590. DOI: 10.1371/journal.pone.0068590

Stein, K., Csiki, Z., Curry Rogers, K.A., Weishampel, D.B., Redelstorff, R., Carballido, J.L., and Sander, P.M. 2010. Small body size and extreme cortical bone remodeling indicate phyletic dwarfism in Magyarosaurus dacus (Sauropoda: Titanosauria). Proceeding of the Natural Academy of Sciences of the United States of America 107: 9258-9263.

Surkov, M.V., and Benton, M.J. 2004. The basicranium of dicynodonts (Synapsida) and its use in phylogenetic analysis. $\mathrm{Pa}$ laeontology 47: 619-638.

Tauber, A.A. 2007. Primer yacimiento de dinosaurios (Cretácico Superior) de la provincia de La Rioja, Argentina. Ameghiniana 44: 11-28. 
Tsunoda, A., Okuda, O., and Sato, K. 1997. The pituitary height may reflect physiological neuroendocrine differences between younger and older subjects and between male and female subjects. American Society of Neuroradiology AJNR 18: 551-554.

Tykoski, R.S. 1998. [The osteology of Syntarsus kayentakatae and its implications for ceratosaurid phylogeny. Master Thesis. University of Texas, Austin, 216 p. Unpublished.].

Upchurch, P. 1995. The evolutionary history of sauropod dinosaurs. Philosophical Transactions of the Royal Society of London B 349: 365-390.

Upchurch, P. 1999. The phylogenetic relationships of the Nemegtosauridae (Saurischia, Sauropoda). Journal of Vertebrate Paleontology 19: 106-125.

Upchurch, P., and Barrett, P.M. 2000. The evolution of sauropod feeding mechanisms. In: H.D. Sues (Ed.), Evolution of Herbivory in Terrestrial Vertebrates: Perspectives from the Fossil Record. Cambrigde University Press, Cambridge, p. 79-122.

Upchurch, P., Barrett, P.M., and Dodson, P. 2004. Sauropoda. In: D.B. Weishampel, P. Dodson, and H. Osmólska (Eds.), The Dinosauria. University California Press, Berkeley, p. 259-322.

Vianey-Liaud, M., Mallan, P., Buscail, O., and Montgelard, C. 1994. Review of French dinosaur eggshells: morphology, structure, mineral, and organic composition. In: K. Carpenter, K.F. Hirsch, and J.R. Horner (Eds.), Dinosaur Eggs and Babies. Cambridge University Press, Cambridge, p. 151-183.

Vilá, B., Galobart, A., Bravo, A.M., and Oms, O. 2006. Megaloolithid eggs from a new Upper Cretaceous locality in the SouthEastern Pyrenees: preliminary data. Ameghiniana, Suplemento Resúmenes 43: 20R.

Vilá, B., Galobart, A., Oms, O., Poza, B., and Bravo, A.M. 2010a. Assessing the nesting strategies of Late Cretaceous titanosaurs: 3-D clutch geometry from a new megaloolithid eggsite. Lethaia 43: 197-208.

Vilá, B., Jackson, F.D., Fortuny, J., Sellés, A.G., and Galobart, A. 2010b. 3-D Modelling of Megaloolithid clutches: insights about nest construction and dinosaur behaviour. PLOS ONE 5: e10362. doi: 10.1371/journal. pone.0010362.

Vizcaíno, S.F., and Milne, N. 2002. Structure and function in armadillo limbs (Mammalia, Xenarthra: Dasypodidae). Journal of Zoology 257: 117-127.

Wedel, M.J. 2003. Vertebral pneumaticity, air sacs, and the physiology of sauropod dinosaurs. Paleobiology 29: 243-255.

Wedel, M.J. 2007. What pneumaticity tells us about "prosauropods", and vice versa. Special Papers in Palaeontology 77: 207-222.

Wedel, M.J. 2009. Evidence for bird-like air-sacs in saurischian dinosaurs. Journal of Experimental Zoology A 311: 611-628.

Wedel, M.J., and Taylor, M.P. 2013. Caudal pneumaticity and pneumatic hiatuses in the sauropod dinosaurs Giraffatitan and Apatosaurus. PLoS ONE 8: e78213. DOI: 10.1371/journal.pone. 0078213

Wedel, M.J., Cifelli, R.L., and Sanders, R.K. 2000. Osteology, paleobiology, and relationships of the sauropod dinosaur Sauroposeidon. Acta Palaeontologica Polonica 45: 343-388.

Weishampel, D.B., Fastovsky, D.E., Watabe, M., Varricchio, D., Jackson, F., Tsogtbaatar, K., and Barsbold, R. 2008. New oviraptorid embryos from Bugin-Tsav, Nemegt Formation (Upper Cretaceous), Mongolia with insights into their habitat and growth. Journal of Vertebrate Paleontology 28: 1110-1119.

Whitlock, J.A. 2011. Inferences of Diplodocoid (Sauropoda: Dinosauria) feeding behavior from snout shape and microwear analyses. PLOS ONE 6: e18304. DOI: 10.1371/journal.pone. 0018304

Whitlock, J.A., Wilson, J.A., and Lamanna, M.C. 2010. Description of a nearly complete juvenile skull of Diplodocus (Sauropoda: Diplodocoidea) from the Late Jurassic of North America. Journal of Vertebrate Paleontology 30: 442-457.

Wilhite, R. 2003. [Biomechanical reconstruction of the appendicular skeleton in three North American Jurassic Sauropods. PhD dissertation. Louisiana State University, Baton Rouge, 185 p. Unpublished.].

Wilson, J.A. 2002. Sauropod dinosaur phylogeny: critique and cladistic analysis. Zoological Journal of the Linnean Society 136: 217-276.

Wilson, J.A. 2005a. Overview of Sauropod phylogeny and evolution. In: K.A. Curry Rogers, and J.A. Wilson (Eds.), The Sauropods: Evolution and Paleobiology. University of California Press, Berkeley, p. 15-49.

Wilson, J.A. 2005b. Redescription of the mongolian sauropod Nemegtosaurus mongoliensis Nowinski (Dinosauria: Saurischia) and comments on Late Cretaceous sauropod diversity. Journal of Systematic Palaeontology 3: 283-318.

Wilson, J.A., and Carrano, M.T. 1999. Titanosaurs and the origin of "wide-gauge" trackways: a biomechanical and systematic perspective on sauropod locomotion. Paleobiology 25: 252-267.

Wilson, J.A., and Sereno, P.C. 1998. Early evolution and higher-level phylogeny of sauropod dinosaurs. Journal of Vertebrate Paleontology, Memoir 5: 1-68.

Wilson, J.A., and Upchurch, P. 2003. A revision of Titanosaurus Lydekker (Dinosauria-Sauropoda), the first dinosaur genus with a "Gondwanan" distribution. Journal of Systematic Palaeontology 1: 125-160.

Wilson, J.A., Mohabey, D.M., Peters, S.E., and Head, J.J. 2010. Predation upon hatchling dinosaur by a new snake from the Late Cretaceous of India. PlosBiol 8: e1000322. doi: 10.1371/journal.Pbio.1000322.

Witmer, L.M., and Ridgely, R.C. 2009. New insights into the brain, braincase, and ear region of Tyrannosaurus (Dinosauria, Theropoda), with implications for sensory organization and behavior. The Anatomical Record 292: 1266-1296.

Witmer, L.M., Chatterjee, S., Franzosa, J., and Rowe, T. 2003. Neuroanatomy of flying reptiles and implications for flight posture behavior. Nature 425: 950-953.

Witmer, L.M., Ridgely, R.C., Dufeau, D.L., and Semones, M.C. 2008. Using CT to peer into the past: 3D visualization of the brain and ear regions of birds, crocodiles, and nonavian dinosaurs. In: $\mathrm{H}$. Endo, and R. Frey (Eds.), Anatomical Imaging: Towards a New Morphology. Springer-Verlag, Tokyo, p. 67-87.

Woodward, H.N., and Lehman, T.M. 2009. Bone histology of and microanatomy of Alamosaurus sanjuanensis (Sauropoda: Titanosauria) from the Maastrichtian of Big Bend National Park, Texas. Journal of Vertebrate Paleontology 29: 807-821.

Xu, X., Zhang, X., Tan, Q., Wang, J., Zhao, X., and Tan, L. 2006. A new titanosaurian sauropod from the Late Cretaceous of Nei Mongol, China. Acta Geologica Sinica 80: 20-26.

Young, C.C. 1941. A complete osteology of Lufengosaurus huenei Young (gen. et sp. nov.) from Lufeng, Yunnan, China. Palaeontologica Sinica, Series C 7: 1-53.

Yates, A.M., Wedel, M.J., and Bonnan, M.F. 2012. The early evolution of postcranial skeletal pneumaticity in sauropodomorph dinosaurs. Acta Palaeontologica Polonica 57: 85-100.

Zaher, H., Pol, D., Carvalho, A.B., Nascimento, P.M., Riccomini, C., Larson, P., Juarez-Valieri, R., Pires-Domingues, R., da Silva Jr., N.J., and de Almeida Campos, D. 2011. A Complete Skull of an Early Cretaceous Sauropod and the evolution of advanced Titanosaurians. PLoS ONE 6: e16663. DOI: 10.1371/journal.pone. 0016663 
AMEGHINIANA - 2015 - Volume 52 (1): 29 - 68

Zhao, Z. 1979. The advancement of research on the dinosaurian eggs in China. In: Institute of Vertebrate Paleontology, Paleoantropology and Nanjing Institute of Paleontology (Eds.), Mesozoic and Cenozoic Rebeds in Southern China. Science Press, p. $330-340$.

Zheng, Z. 1996. [Cranial anatomy of Shunosaurus and Camarasaurus (Dinosauria: Sauropoda) and the phylogeny of the Sauropoda. PhD Thesis, Texas Tech University, Lubbock, Unpublished.].

doi: 10.5710/AMGH.16.07.2014.829

Submitted: April 5 $5^{\text {th }}, 2013$

Accepted: July $16^{\text {th }}, 2014$ 